\title{
WATER QUALITY, SEASONAL WATER-LEVEL CHANGES, 1988-89, AND SIMULATED EFFECTS OF INCREASED WATER USE FROM THE OZARK AQUIFER NEAR BRANSON, MISSOURI
}

By Jeffery L. Imes

U.S. GEOLOGICAL SURVEY

Water-Resources Investigations Report 91-4057

Prepared in cooperation with the CITY OF BRANSON

and the

MISSOURI DEPARTMENT OF NATURAL RESOURCES, DIVISION OF ENVIRONMENTAL QUALITY 


\section{U.S. DEPARTMENT OF THE INTERIOR \\ MANUEL LUJAN, JR., Secretary \\ U.S. GEOLOGICAL SURVEY \\ Dallas L. Peck, Director}

For additional information

write to:

District Chief

U.S. Geological Survey

1400 Independence Road

Mail Stop 200

Rolla, Missouri 65401
Copies of this report can

be purchased from:

U.S. Geological Survey

Books and Open-File Reports

Federal Center, Bldg. 810

Box 25425

Denver, Colorado 80225 


\section{CONTENTS}

Page

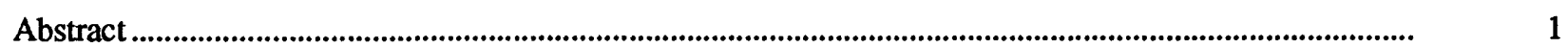

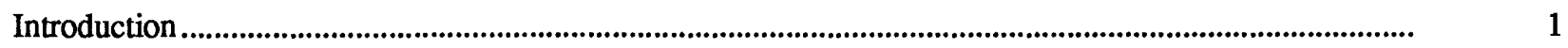

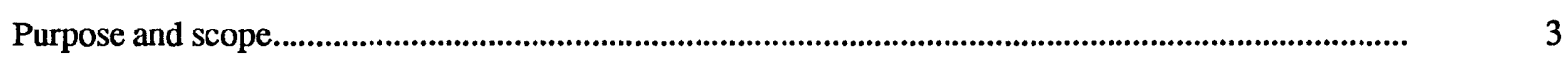

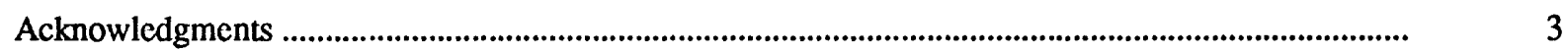

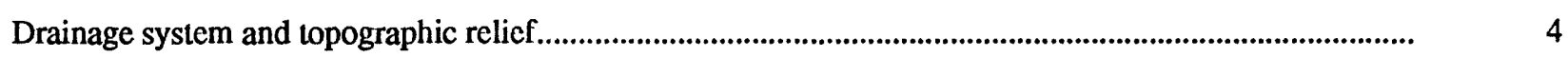

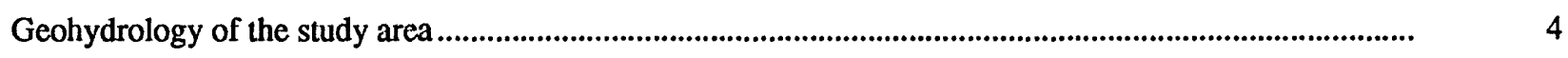

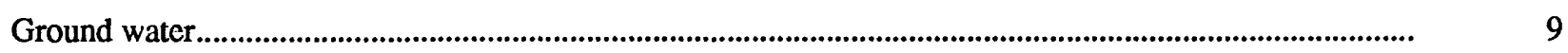

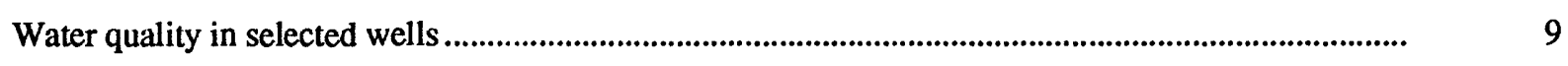

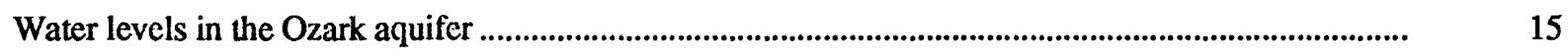

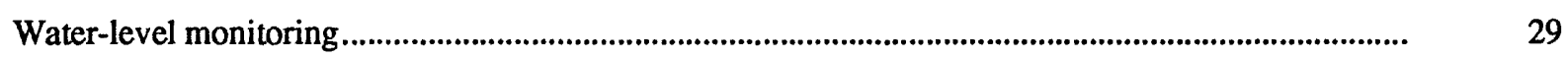

Water use by municipalities, public water-supply districts, and selected businesses..............................

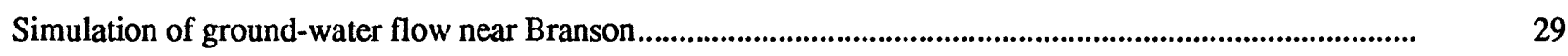

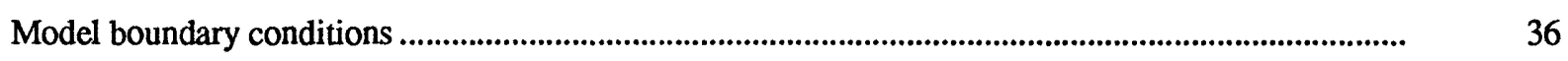

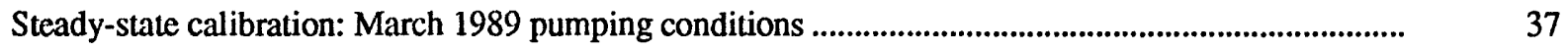

Steady-state simulation: predevelopment conditions with lakes .............................................................. 40

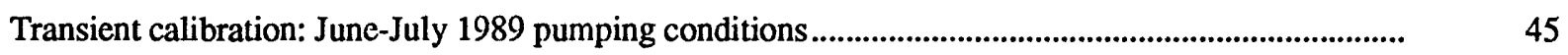

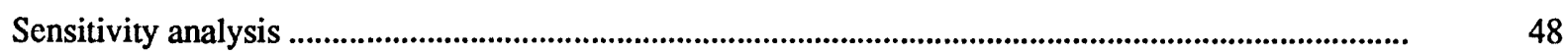

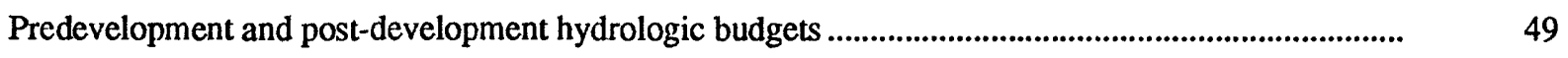

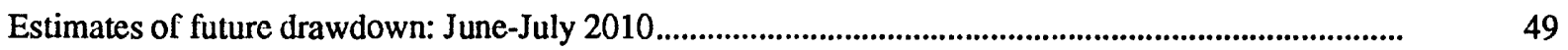

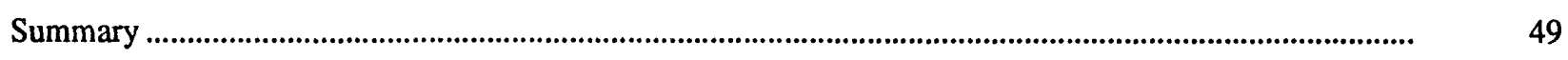

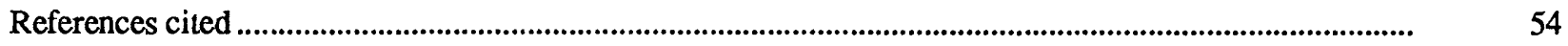




\section{ILLUSTRATIONS}

Figures 1-13. Maps showing:

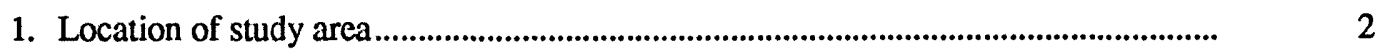

2. Principal streams and faults .............................................................................. 5

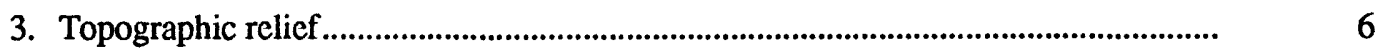

4. Outcrop arca of regional geohydrologic units..................................................................

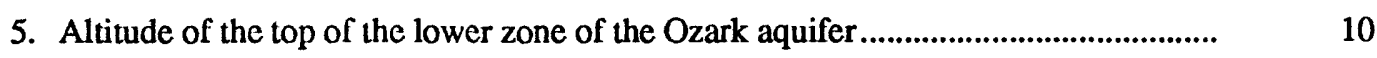

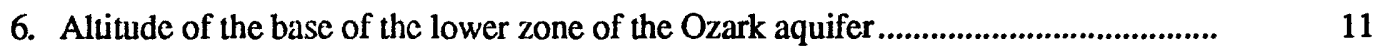

7. Location of wells in which water-quality samples were collected and analyzed for selected inorganic constituents and volatile organic compounds.

8. Predevelopment potentiometric surface of the upper zone of the Ozark aquifer.........

9. Location of wells in which water levels were measured and reported in table 4 and location of water-level monitoring wells

10. Potentiometric surface of the upper and lower zones of the Ozark aquifer, summer 1987

11. Potentiometric surface of the upper and lower zones of the Ozark aquifer, June-July 1988

12. Potentiometric surface of the upper and lower zones of the Ozark aquifer, March 1989

13. Potentiometric surface of the upper and lower zones of the Ozark aquifer, June-July 1989

14. Graph showing water levcls in well 125 (City of Branson "Michel" Well) and well 144 (Gateway subdivision)

15. Map showing location of wells for which monthly ground-water-use data were collected

16. Map showing extent of modeled area and relative size of model grid cells

17. Geohydrologic section showing relative thickness of the regional geohydrologic units and the model layer representing aquifer units 


\section{ILLUSTRATIONS--Continued}

Figures 18-24. Maps showing:

18. Measured and simulated potentiometric surface of the upper zone of the Ozark aquifer, March 1989

19. Measured and simulated potentiometric surface of the lower zone of the Ozark aquifer, March 1989

20. Simulated predevelopment potentiometric surface of the upper zone of the Ozark aquifer, including the effect of Table Rock Lake, Lake Taneycomo, and Bull Shoals Lake.

21. Simulated predevelopment potentiometric surface of the lower zone of the Ozark aquifer, including the effect of Table Rock Lake, Lake Taneycomo, and Bull Shoals Lake

22. Drawdown in the upper and lower zones of the Ozark aquifer resulting from pumping stresses in March 1989.

23. Measured and simulated potentiometric surface of the upper zone of the Ozark aquifer, June-July 1989

24. Measured and simulated potentiometric surface of the lower zone of the Ozark aquifer, June-July 1989

25. Diagram showing the predevelopment water budget (including lakes) and the March 1989 water budget

26. Map showing pumpage induced drawdown in the upper zone of the Ozark aquifer from June 1989 to June 2010 .

27. Map showing pumpage induced drawdown in the lower zone of the Ozark aquifer from June 1989 to June 2010 


\section{TABLES}

Table 1. Generalized relation of stratigraphic units and geohydrologic units in the

Branson area

2. Results of specific conductance measurements, fecal coliform bacteria count, and analyses of water samples for selected inorganic species for water samples collected in September 1988

3. Well information, volatile organic compounds, and detection limits for water samples collected in September 1988

4. Depth to water in selected deep and shallow wells.

5. Monthly ground-water use by the primary ground-water users in the Branson area.........

6. Sensitivity of calibrated June 1989 model simulation to changes in hydraulic variables. 


\section{CONVERSION FACTORS AND VERTICAL DATUM}

Multiply inch-pound unit

foot

mile

foot per second

cubic foot per second

million gallons per month

degree Fahrenheit $\left({ }^{\circ} \mathrm{F}\right)$
By

0.3048

1.609

0.3048

0.02832

3,785

${ }^{\circ} \mathrm{C}=5 / 9 \times\left({ }^{\circ} \mathrm{F}-32\right)$
To obtain metric (SI) unit

meter

kilometer

meter per second

cubic meter per second

cubic meter per month

degrees Celsius $\left({ }^{\circ} \mathrm{C}\right)$

Sea level: In this report "sea level" refers to the National Geodetic Vertical Datum of 1929 (NGVD of 1929)--a geodetic datum derived from a general adjustment of the first-order level nets of both the United States and Canada, formerly called Sea Level Datum of 1929. 


\title{
WATER QUALITY, SEASONAL WATER-LEVEL CHANGES, 1988-89, AND SIMULATED EFFECTS OF INCREASED WATER USE FROM THE OZARK AQUIFER NEAR BRANSON, MISSOURI
}

\author{
By \\ Jeffrey L. Imes
}

\begin{abstract}
Branson, Missouri, is the center of a rapidly developing retirement community and tourist industry spurred by the attractions offered by three large lakes nestled in the scenic Ozark Mountains of southwest Missouri. A consequence of the large influx of tourists to the area in the warmer months is a large increase in demand for potable water to supply recreation facilities and other commercial establishments, lodging facilities, and residences. The rapid pace of business and residential expansion has created concerns regarding the future ground-water quality and availability.
\end{abstract}

A reconnaissance survey to determine water quality in 34 wells open to the Ozark aquifer indicates specific conductance ranged from 347 to 841 microsiemens per centimeter at 25 degrees Celsius, and no fecal coliform bacteria were present in any well. Chloride and nitrate concentrations in all wells were considerably less than the Missouri Department of Natural Resources criteria for public-drinking water supply of 250 milligrams per liter and 10 milligrams per liter. Analysis of 5 water samples for 33 volatile organic compounds failed to detect any concentrations in excess of the detection limits.

Water-level measurements in wells open to different geologic formations that collectively comprise the Ozark aquifer indicate that the combined Cotter and Jefferson City Dolomites form an upper zone that is less permeable than the sequence of rocks from the Roubidoux Formation to the Potosi Dolomite, which is the lower zone within the aquifer. Water levels measured in the Ozark aquifer near Branson during the summer of 1988 and March 1989 indicate water levels increasing in 23 wells, decreasing in 2 wells, and remaining the same in 1 well. The water-level increases ranged from 4 to 111 feet. Water levels measured in the summer of 1989 indicate water levels generally declining to levels similar to those in the summer of 1988. The water-level measurements indicate no evidence of regional water-level decline from summer 1988 to summer 1989.

Monthly water-use data for September 1988 to February 1990, collected from selected large water users in the Branson area, indicate pumping rates in individual wells range from zero to about 18 million gallons per month. The water-use data were used to calibrate a three-dimensional model of ground-water flow in the upper and lower zones of the Ozark aquifer. The model was used to estimate the increase in drawdown from June 1989 to June 2010, assuming the large water users will increase pumping rates by 20 percent every 10 years. Maximum additional drawdown to June 2010 caused by the increased pumping rates is estimated at about 10 feet in the upper zone and about 30 feet in the lower zone.

\section{INTRODUCTION}

Branson, Missouri, and the surrounding area have experienced rapid population growth in the past twenty years because of the presence and popularity of three large lakes (Table Rock Lake, Lake Taneycomo, and Bull Shoals Lake) in this scenic region of the Ozark Mountains of southwestern Missouri (fig. 1). According to the 1980 census, the populations of Taney and Stone Counties were 20,500 and 15,600; this is about double the 1960 census figures (State of Missouri, 1890-1988). The population increase is largest in Branson, a small community on the shore of Lake Taneycomo about 8 river mi (mile) downstream from Table Rock Dam. Most of the population increase has resulted from 


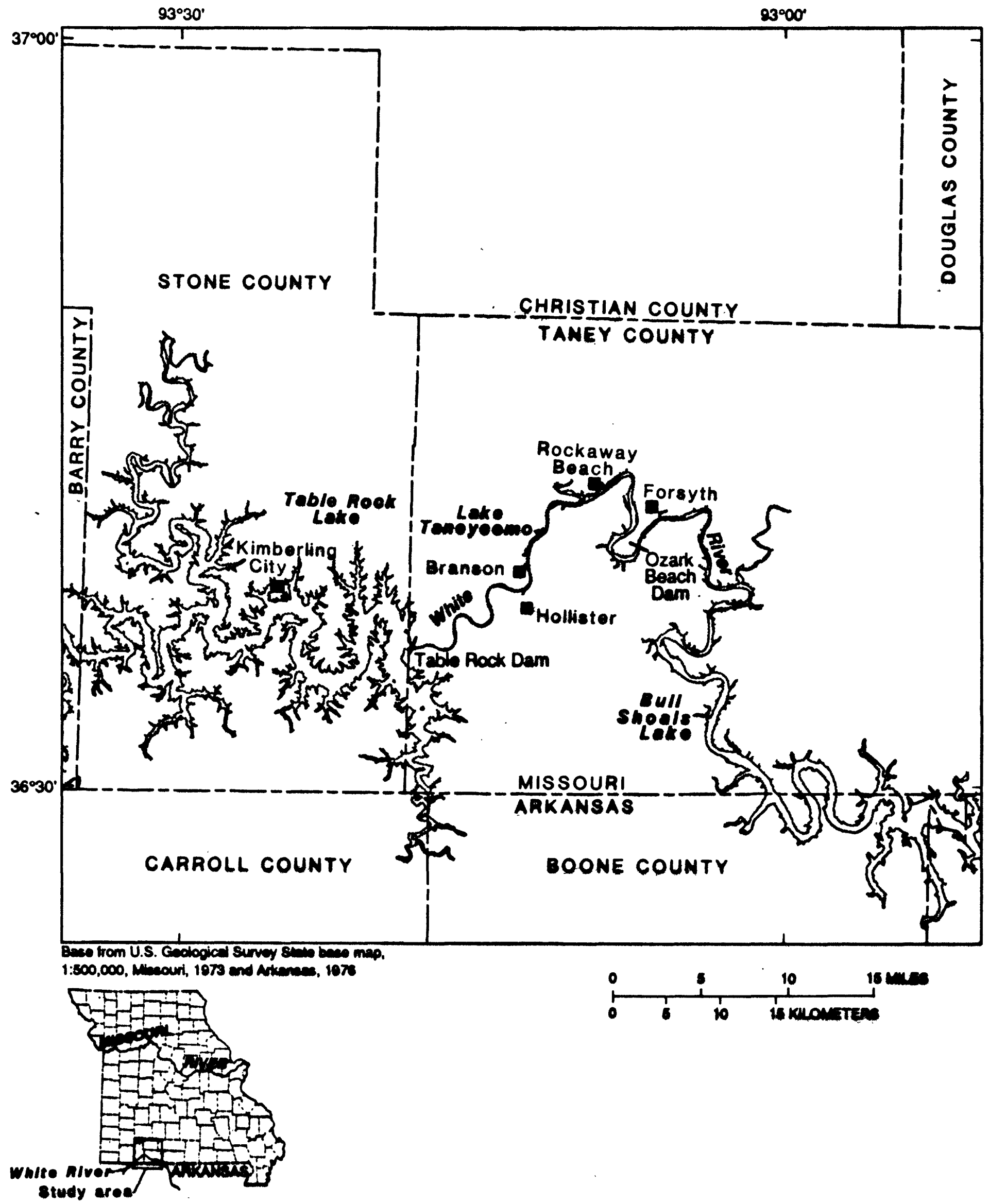

Figure 1.--Location of study eren. 
a steady movement of retirees into the area, who are attracted by the mild climate and the recreation facilities offered by the lakes. In addition to the increase in the number of permanent residents, the area also hosts a large influx of tourists in the summer. The number of tourists generally exceeds the permanent resident population of the area. The number of commercial establishments in the city has increased markedly to accommodate the tourists.

The permanent and seasonal population increases and resulting growth in commercial establishments and recreational facilities have greatly increased the demand for potable water and increased concerns about water quality in the area. The city of Branson recently acquired three additional water-supply wells, and several recreational industries have drilled large-capacity supply wells. Smaller communities around Branson have similar increased demands for water. Many new shallow wells have been drilled to provide rural residences with water. One consequence of the increased demand for water is a lowering of the potentiometric surface of the Ozark aquifer, the aquifer that supplies most of the ground water in the area. Because most of the increased water demand occurs during the summer tourist season, water levels are lowered substantially in the summer but recover during the winter. A study was conducted by the U.S. Geological Survey, in cooperation with the City of Branson and the Missouri Department of Natural Resources, Division of Environmental Quality, to address the concerns about water quality and the hydrologic effects of increasing water demand.

\section{Purpose and Scope}

This report presents the results of a study designed to provide a reconnaissance of ground-water quality in the Branson area and to determine whether water levels in the Ozark aquifer are recovering fully in the intervening winter period of lesser water use, or are in a state of continued long-term decline as a result of the cumulative effect of the large summer water withdrawals. Ground-water samples for water-quality analyses were collected from 34 wells in the summer of 1988 . The 2-year study also was designed to permit measurements of ground-water levels near Branson during the summers of 1988 and 1989 and the winter of 1989 . The water-level data were used to assess the effect of the larger summer pumping rates on the potentiometric surface of the Ozark aquifer.

A digital model of ground-water flow was used to test concepts of ground-water movement in the Ozark aquifer and to estimate the probable changes in ground-water levels that will result from continued use of the Ozark aquifer as a source of water supply for Branson and surrounding communities. The calibrated model was used to estimate the effect of continued ground-water withdrawals and changing water-use patterns in the Branson area. Because of boundary-condition requirements of the model, the study area is considerably larger than the immediate vicinity of Branson. The study area includes most of Taney and Stone Counties, the southern one-half of Christian County, and a small part of Douglas County, Missouri, and parts of Boone and Carroll Counties in northern Arkansas. However, data collection has been concentrated near Branson.

\section{Acknowledoments}

Many individuals contributed to this project by providing water-use information and giving permission to make water-level measurements and collect water samples in their business or private water wells. Although it is not possible to list every person whose contribution has helped make this project successful, thanks are extended to each of these persons. Special thanks are given to the personnel of the city of Branson for conducting water-level measurements and providing water-use data. Pat McAbee, Superintendent, city of Branson and his predecessor, Jane Evans, were especially helpful. Also, Roy Smead of Tri-State Utilities is thanked for his diligence in providing water-use data and general information about aquifer properties in the Branson area. 


\section{DRAINAGE SYSTEM AND TOPOGRAPHIC RELIEF}

Several large well-entrenched streams flow through the study area. The largest, the White River, no longer flows freely but is represented by Table Rock Lake, Lake Taneycomo, and Bull Shoals Lake (fig. 2). Table Rock Dam was completed during 1958, Lake Taneycomo was formed after Ozark Beach Dam was built during 1913, and Bull Shoals Dam was completed during 1951. The average level of Table Rock Lake is $915 \mathrm{ft}$ (feet), of Lake Taneycomo is $700 \mathrm{ft}$, and of Bull Shoals Lake is $650 \mathrm{ft}$. The James River, Bull Creek, Swan Creek, and Beaver Creek flow into the chain of lakes from the north. Low-flow indices determined from streamflow measurements at gaging stations on these streams range from a 7-day $Q_{2}$ (average minimum flow for 7 consecutive days that has a 2-year recurrence interval) of $100 \mathrm{ft}^{3} / \mathrm{s}$ (cubic feet per second) on the James River to $3 \mathrm{ft}^{3} / \mathrm{s}$ on Bull Creek (fig. 2). Although no base-flow measurements are available for Bear Creek (Missouri), which is a tributary of Bull Creek, Bear Creek apparently has a substantial base flow and is included with the larger streams as part of the study. Long Creek and Bear Creek, Arkansas (not the tributary Bear Creek previously mentioned) flow into the chain of lakes from the south (fig. 2).

The altitude of the land surface in the study area ranges from about $700 \mathrm{ft}$ to about $1,400 \mathrm{ft}$ (fig. 3 ). The erosional valley of the White River is oriented approximately west to east across the study area and the larger valleys eroded by tributaries of the White River are oriented north to northeast. Areas of greatest altitude north of the lakes generally are located between the James River and Bull Creek, and those south of the lakes generally are located west of Bear Creek.

\section{GEOHYDROLOGY OF THE STUDY AREA}

The deeply entrenched White River valley (fig. 3) is the major discharge area for regional groundwater flow in southern Missouri and northern Arkansas. The original White River channel, now the bottom of the present chain of lakes, was incised into Ordovician bedrock, primarily the Cotter and Jefferson City Dolomites. Upland areas north and south of the river generally are covered by a thin Mississippian shale and shaley limestone, primarily the Northview Shale, and thicker Mississippian cherty limestone, primarily the Burlington and Keokuk Limestones (table 1). The continuity of geologic formations in the study area is disrupted by several faults, most notably the Ten O'Clock Run fault, a northwesterly oriented fault southwest of Branson (fig. 2).

The principal regional geohydrologic units in the Branson area were previously identified and mapped as part of a study of the Ozark Plateaus aquifer system (Imes and Emmett, in press). The units are defined on the basis of regional geohydrologic properties. Six units are represented in the study area; however, not all of the stratigraphic units that comprise these geohydrologic units are present in the study area. From the stratigraphically youngest to oldest, the units are (1) the Springfield Plateau aquifer, (2) the Ozark confining unit, (3) the Ozark aquifer, (4) the St. Francois confining unit, (5) the St. Francois aquifer, and (6) the Basement confining unit. Three of these regional geohydrologic units are exposed in the study area (fig. 4). The Ozark aquifer is the bedrock unit exposed in the major stream valleys and within the valleys of the more well-entrenched tributary streams. Generally, the Ozark confining unit is exposed as a narrow band along the valley walls, separating the Ozark aquifer from the stratigraphically higher Springfield Plateau aquifer that caps the upland ridges between major stream valleys. A seventh and stratigraphically higher unit, the Western Interior Plains confining system, is present only as an extremely small area of undifferentiated Pennsylvanian rocks in the northwestern corner of the study area (fig. 4). Because the Western Interior Plains confining unit is not present in a sufficient thickness or areal extent in the study area to substantially affect the ground-water flow system, the unit is not considered in this report. Thin Quaternary alluvial deposits of small areal extent are present along the larger stream valleys. These deposits also are not explicitly discussed in this report. The relation between regional geohydrologic units and stratigraphic units within the study area is shown in table 1. 


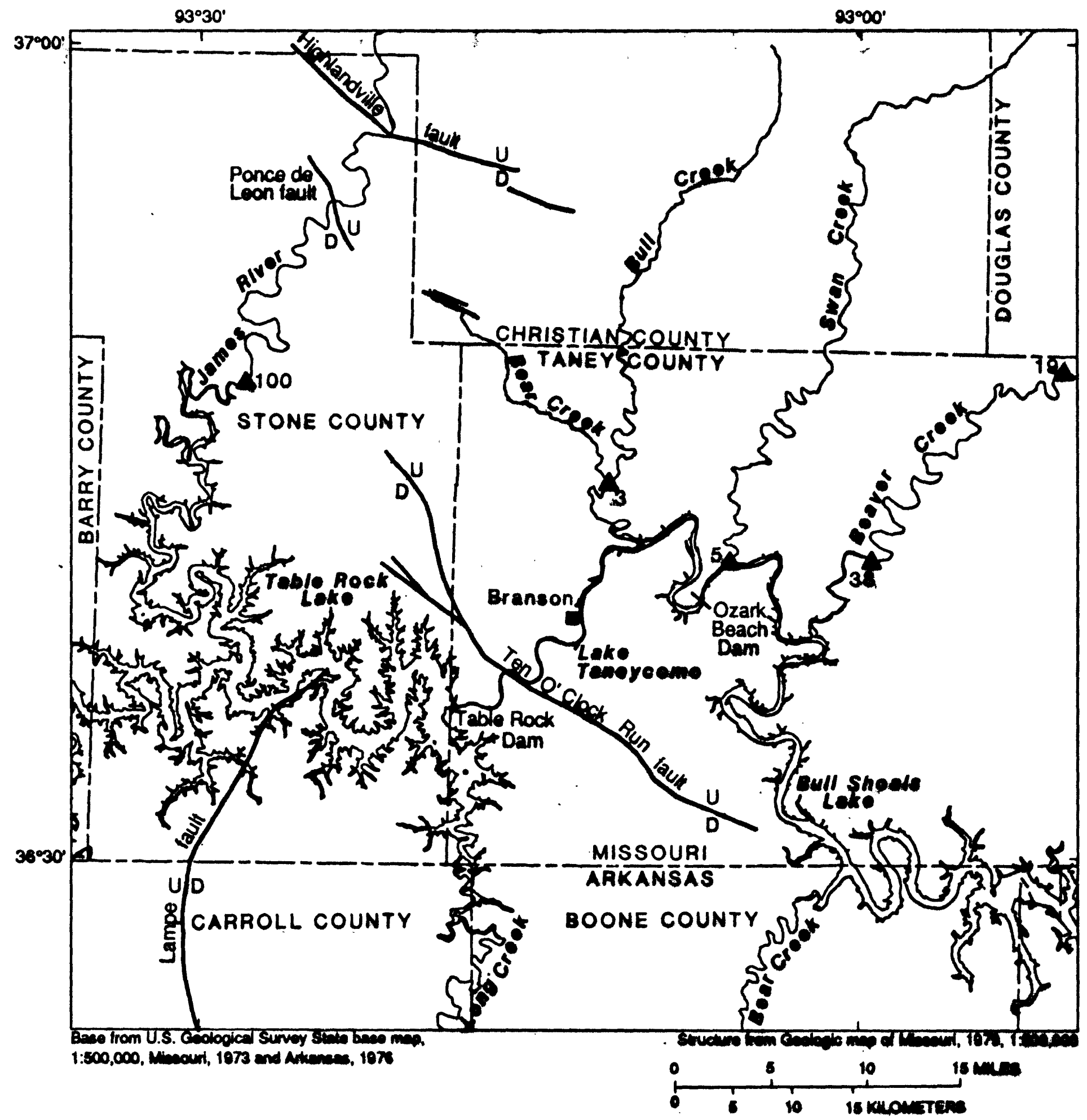

\section{EXPLANATION}

38. GAGING STATION-Number indicates estimated 7-day $Q_{2}$

(average minimum flow for 7 coneecutive days that has

a 2-year nocumenoe interval), in cubic teat par second

$\frac{U}{D}$ FAULT-U, upthrown sido; D. downthrown side

Figure 2.-- Principal streams and faults (moditied trom Imes, 19002). 


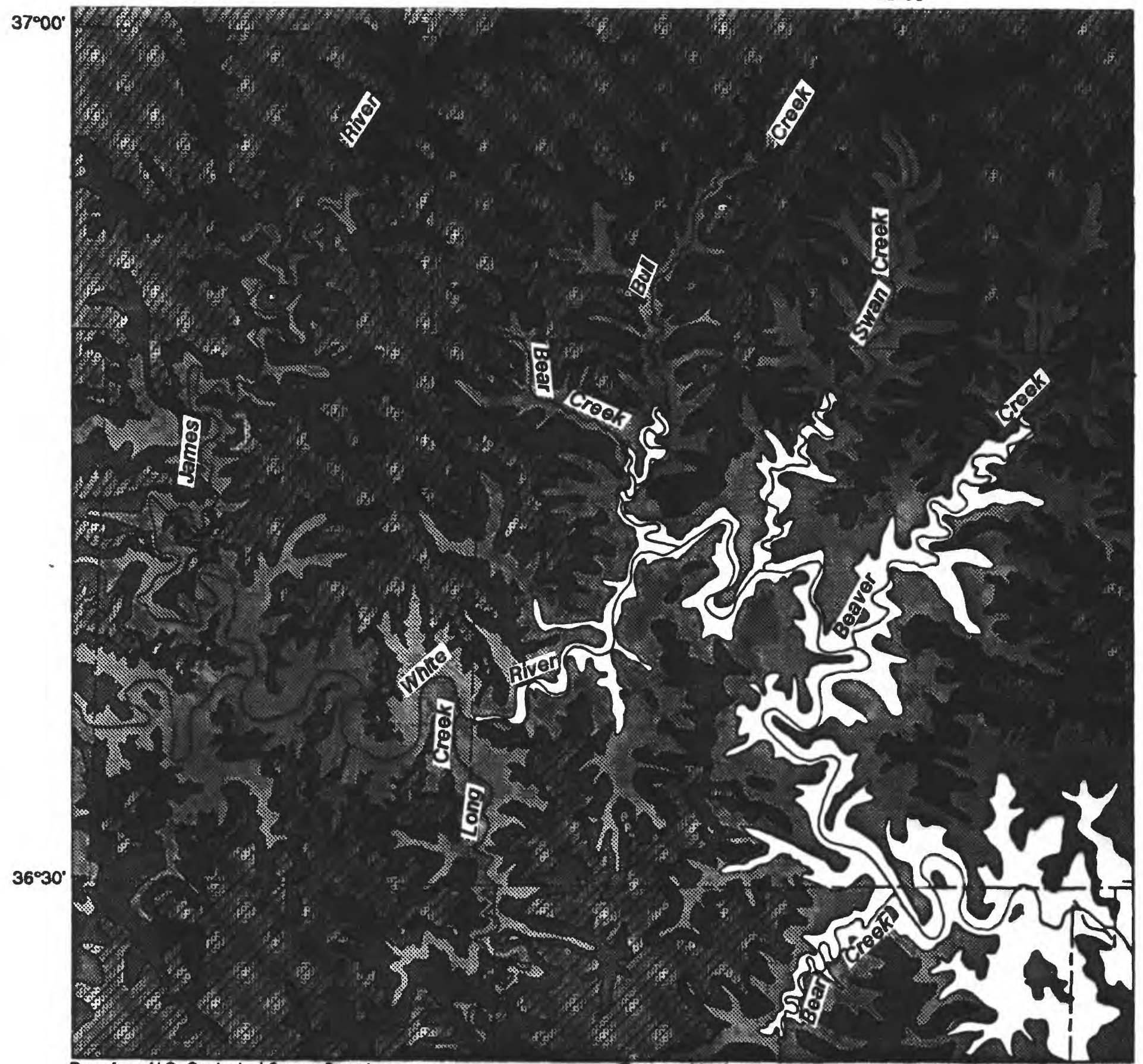

Base from U.S. Geological Survey steb beac map. 1:500,000, Mlosouri, 1973 and Avkenea. 1978

ropogrest

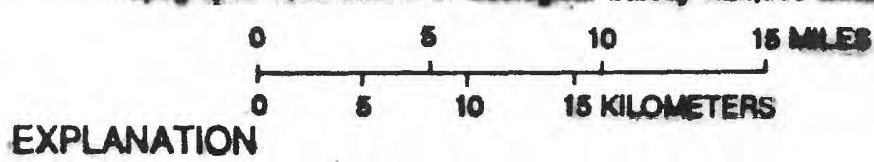

ALTITUDE OF LAND SUAFACE, IN FEET ABOVE SEA LEVEL

D 600 to 800

800101,000

D 1,000 to 1,200

Greater than 1,200

Figure 3.--Topographic relief. 
Table 1.--Generalized relation of stratigraphic units and geohydrologic units in the Branson area

\begin{tabular}{|c|c|c|c|}
\hline $\begin{array}{l}\text { Regional } \\
\text { geohydrologic } \\
\text { system }\end{array}$ & $\begin{array}{c}\text { Regional } \\
\text { geohydrologic } \\
\text { unit }\end{array}$ & Principal stratigraphic unit(s) & $\begin{array}{l}\text { Time- } \\
\text { stratigraphic } \\
\text { unit }\end{array}$ \\
\hline \multirow{6}{*}{$\begin{array}{l}\text { Ozark } \\
\text { Plateaus } \\
\text { aquifer } \\
\text { system }\end{array}$} & $\begin{array}{l}\text { Springfield } \\
\text { Plateau } \\
\text { aquifer }\end{array}$ & $\begin{array}{l}\text { St. Louis Limestone, Salem Limestone, } \\
\text { Warsaw Limestone, Boone Formation, } \\
\text { St. Joe Limestone Member of Boone } \\
\text { Formation, Keokuk Limestone, } \\
\text { Burlington Limestone, Elsey Formation, } \\
\text { Reeds Spring Formation, Grand Falls } \\
\text { Formation, and Pierson Formation }\end{array}$ & Mississippian \\
\hline & $\begin{array}{l}\text { Ozark } \\
\text { confining } \\
\text { unit }\end{array}$ & $\begin{array}{l}\text { Northview Shale, Sedalia } \\
\text { Limestone, Compton } \\
\text { Limestone, and Chattanooga } \\
\text { Shale }\end{array}$ & $\begin{array}{l}\text { Lower } \\
\text { Mississippian } \\
\text { and } \\
\text { Upper } \\
\text { Devonian }\end{array}$ \\
\hline & \multirow[t]{2}{*}{$\begin{array}{l}\text { Ozark } \\
\text { aquifer }\end{array}$} & $\begin{array}{l}\text { Clifty Limestone, Penters Chert, } \\
\text { Lafferty Limestone, St. Clair } \\
\text { Limestone, Brassfield Limestone, } \\
\text { Cason Shale, Fernvale Limestone, } \\
\text { Kimmswick Limestone, Plattin } \\
\text { Limestone, Joachim Dolomite, St. } \\
\text { Peter Sandstone, Everton } \\
\text { Formation, Smithville Formation, } \\
\text { Powell Dolomite, Cotter Dolomite, } \\
\text { and Jefferson City Dolomite }\end{array}$ & \multirow[t]{2}{*}{$\begin{array}{l}\text { Middle } \\
\text { Devonian } \\
\text { through } \\
\text { Upper } \\
\text { Cambrian }\end{array}$} \\
\hline & & $\begin{array}{l}\text { Roubidoux Formation, Gasconade } \\
\text { Dolomite, Van Buren Formation, } \\
\text { Gunter Sandstone Member of Van } \\
\text { Buren Formation, Eminence } \\
\text { Dolomite, and Potosi Dolomite }\end{array}$ & \\
\hline & $\begin{array}{l}\text { St. Francois } \\
\text { confining } \\
\text { unit }\end{array}$ & $\begin{array}{l}\text { Doe Run Dolomite, Derby Dolomite, } \\
\text { and Davis Formation }\end{array}$ & $\begin{array}{l}\text { Upper } \\
\text { Cambrian }\end{array}$ \\
\hline & $\begin{array}{l}\text { St. Francois } \\
\text { aquifer }\end{array}$ & $\begin{array}{l}\text { Bonneterre Dolomite, Reagan } \\
\text { Sandstone, and Lamotte Sandstone }\end{array}$ & $\begin{array}{l}\text { Upper } \\
\text { Cambrian }\end{array}$ \\
\hline & $\begin{array}{l}\text { Basement } \\
\text { confining } \\
\text { unit }\end{array}$ & $\begin{array}{c}\text { Mostly igneous and metamorphic } \\
\text { rocks }\end{array}$ & Precambrian \\
\hline
\end{tabular}



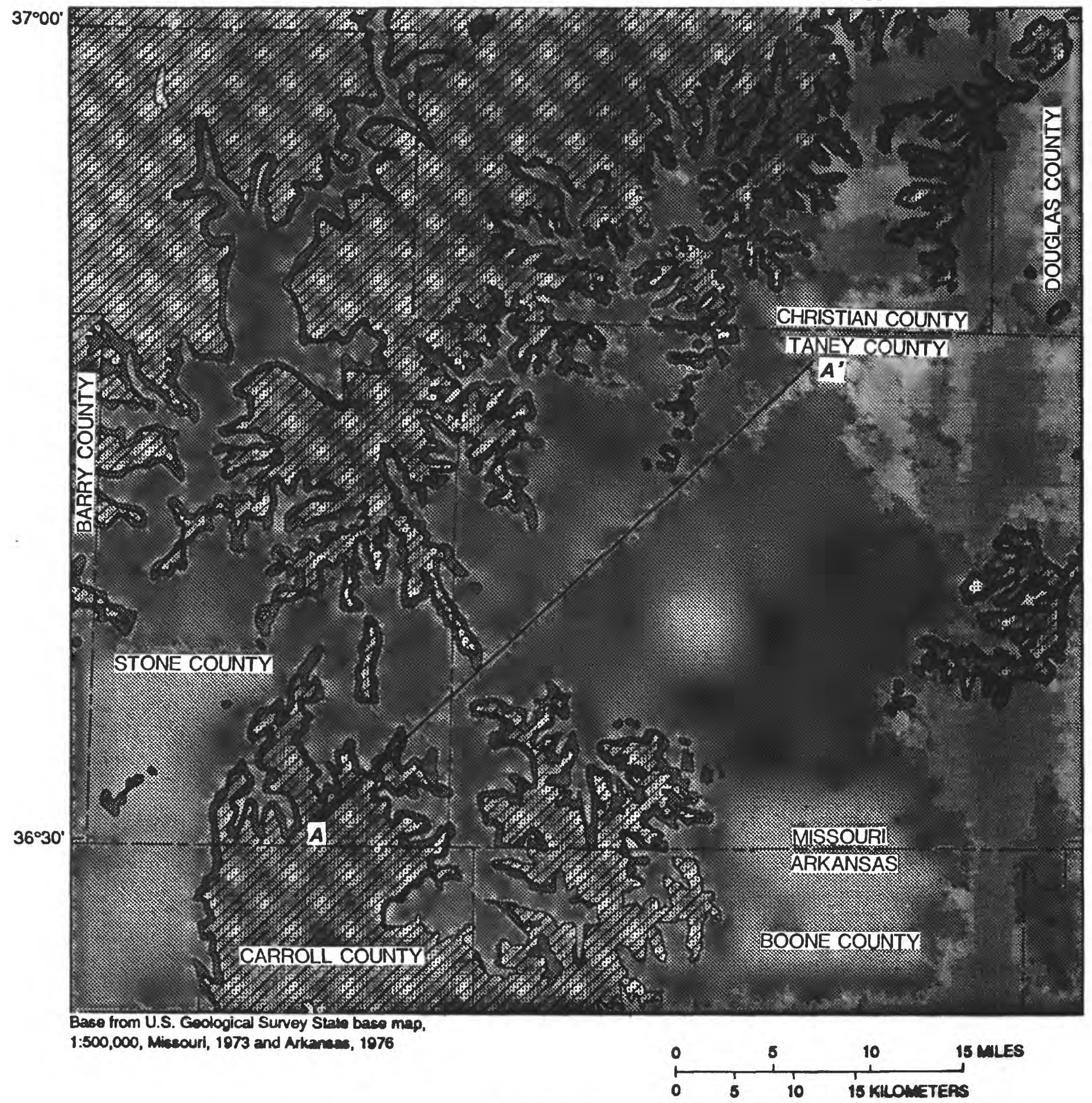

\section{EXPLANATION}

WESTERN INTERIOR PLAINS CONFINING UNIT

SPRINGFIELD PLATEAU AQUIFER

OZ泫 OZARK CONFINING UNIT

OZ. OZARK AQUIFER (UPPER ZONE)

A-A' TRACE OF GEOHYDROLOGIC SECTION SHOWN IN FIGURE 17

Figure 4.--Outcrop area of regional geohydrologic units. 
The Ozark aquifer is the principal aquifer of interest for this study. Many of the stratigraphically higher geologic formations that form the Ozark aquifer are not present in the study area. Generally the uppermost formation in the aquifers is either the Cotter Dolomite or Jefferson City Dolomite; however, the Everton Formation, Smithville Formation, and Powell Dolomite also are present and can be the uppermost formation of the aquifer along the southern margins of the study area. The permeability of the dolostone and sandstone formations that comprise the Ozark aquifer differ sufficiently in the area so that the aquifer can be divided into two reasonably distinct zones. The upper, less-permeable zone includes the Jefferson City Dolomite and overlying formations of the Ozark aquifer where present, and the lower, more-permeable zone includes the Roubidoux Formation, Gasconade Dolomite, Eminence Dolomite, and Potosi Dolomite.

The altitude of the top of the lower zone of the Ozark aquifer ranges from more than $800 \mathrm{ft}$ in the northeast to less than sea level in the southwest (fig. 5). The formations of the lower zone are offset by more than $100 \mathrm{ft}$ along the Ten O'Clock Run fault. The surface of the lower zone contains a shallow basin, elongated to the northeast, that extends from the Ten O'Clock Run fault. Few data are available within the study area with which to construct a contour map of the base of the lower zone. The map presented here is modified from a previously constructed regional-scale map of the top of the St. Francois confining unit (Imes, 1990a). The altitude of the base of the lower zone ranges from near sea level in the northeast along the ridge of a broad, southwest trending anticline to about 1,000 $\mathrm{ft}$ below sea level in the southeast (fig. 6).

The top of the St. Francois aquifer, the lowermost aquifer in the Ozark Plateaus aquifer system, ranges from about $1,500 \mathrm{ft}$ below land surface to about $2,000 \mathrm{ft}$ below land surface. Because adequate quantities of ground water for municipal, recreational, and commercial uses exist in the overlying Ozark aquifer and the St. Francois aquifer is at such great depths, water-supply wells in the study area are not open to the St. Francois aquifer.

\section{GROUND WATER}

\section{Water Quality in Selected Wells}

To address concerns about the quality of water in the Ozark aquifer near Branson, water samples were collected during September 1988 in 34 wells (fig. 7) located primarily near Branson and Forsyth. The specific conductance of each sample and a count of fecal coliform bacteria at $25 \mathrm{~mL}$ (milliliters) and $100 \mathrm{~mL}$ of sample volume was determined in the field. Laboratory analyses for chloride, total nitrite [in $\mathrm{mg} / \mathrm{L}$ (milligrams per liter) of nitrogen], and total nitrite plus nitrate (in $\mathrm{mg} / \mathrm{L}$ of nitrogen) were made for each sample, and total nitrate (in $\mathrm{mg} / \mathrm{L}$ of nitrogen) was calculated from results of the laboratory analyses (table 2). Chemical analyses were made for these inorganic species because the species are indicators of contamination from sewage effluent, a primary concern in the area.

Specific conductance of the samples ranged from 347 to $841 \mu \mathrm{S} / \mathrm{cm}$ (microsiemens per centimeter at $25^{\circ}$ Celsius), and fecal coliform was not detected in any of the samples. Chloride concentrations exceeding the detection limit of $5 \mathrm{mg} / \mathrm{L}$ were in samples from five wells. Water from well 101 had the largest chloride concentration $(81 \mathrm{mg} / \mathrm{L})$; however, this concentration is considerably less than the Missouri Department of Natural Resources (1987) criteria for maximum public drinking water supply of $250 \mathrm{mg} / \mathrm{L}$. Nitrite and nitrite plus nitrate concentrations were determined for 33 samples; one sample container was damaged in transit and the sample was destroyed. Nitrite concentrations in 30 wells were less than detection limits, and 3 samples contained measurable concentrations of nitrite. Nitrite plus nitrate concentrations in 27 wells were less than detection limits, and 6 samples contained measurable concentrations of nitrite plus nitrate. Nitrate concentrations in the samples were calculated from nitrite plus nitrate concentrations minus the nitrite concentrations. The maximum concentration of nitrate determined for the samples was $0.6 \mathrm{mg} / \mathrm{L}$, well below the Missouri Department of Natural Resources recommended criteria for public-drinking water supply of $10 \mathrm{mg} / \mathrm{L}$. 


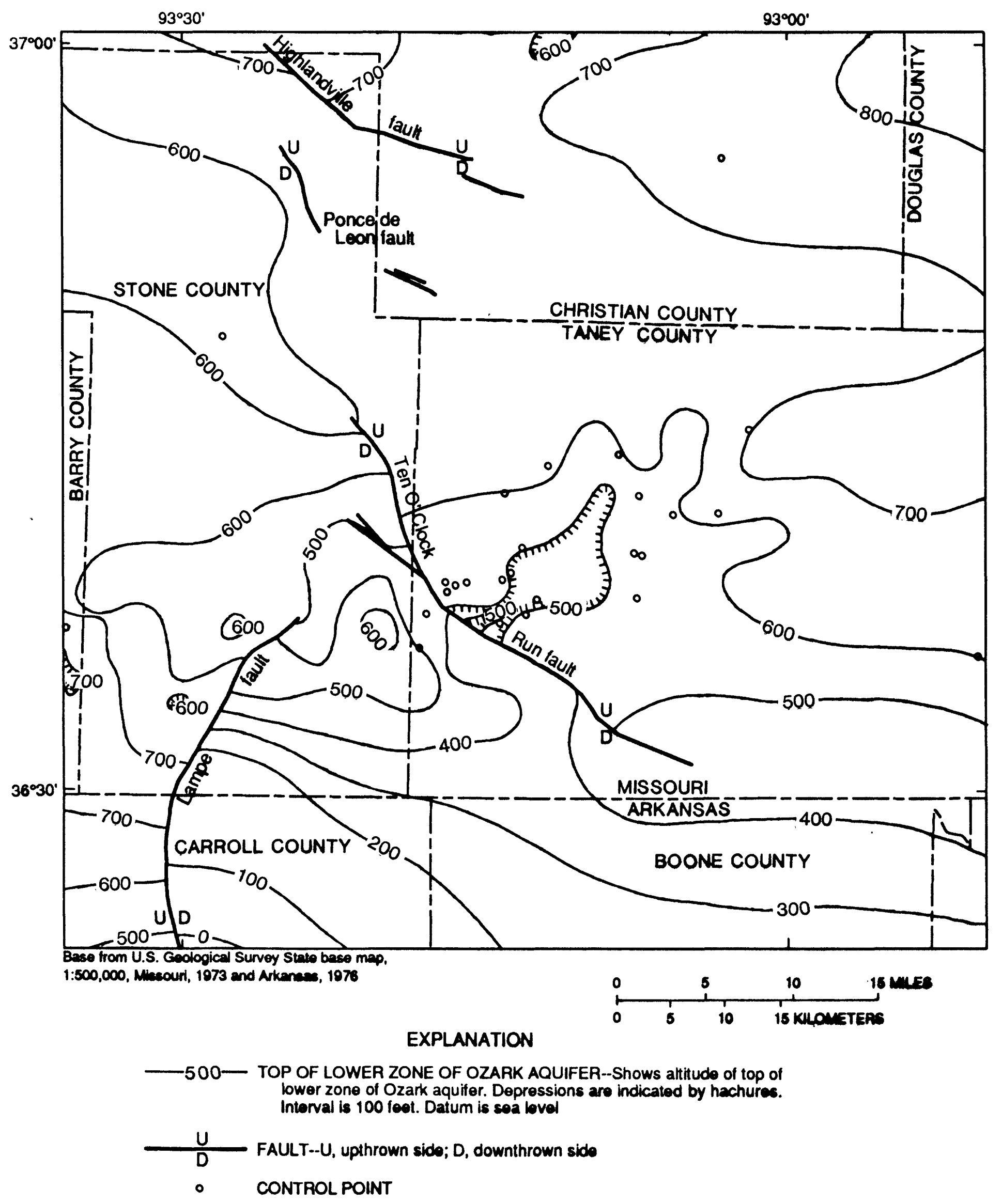

Figure 5.--Altitude of the top of the lower zone of the Ozark aquifer (modified from Melton, 1976). 


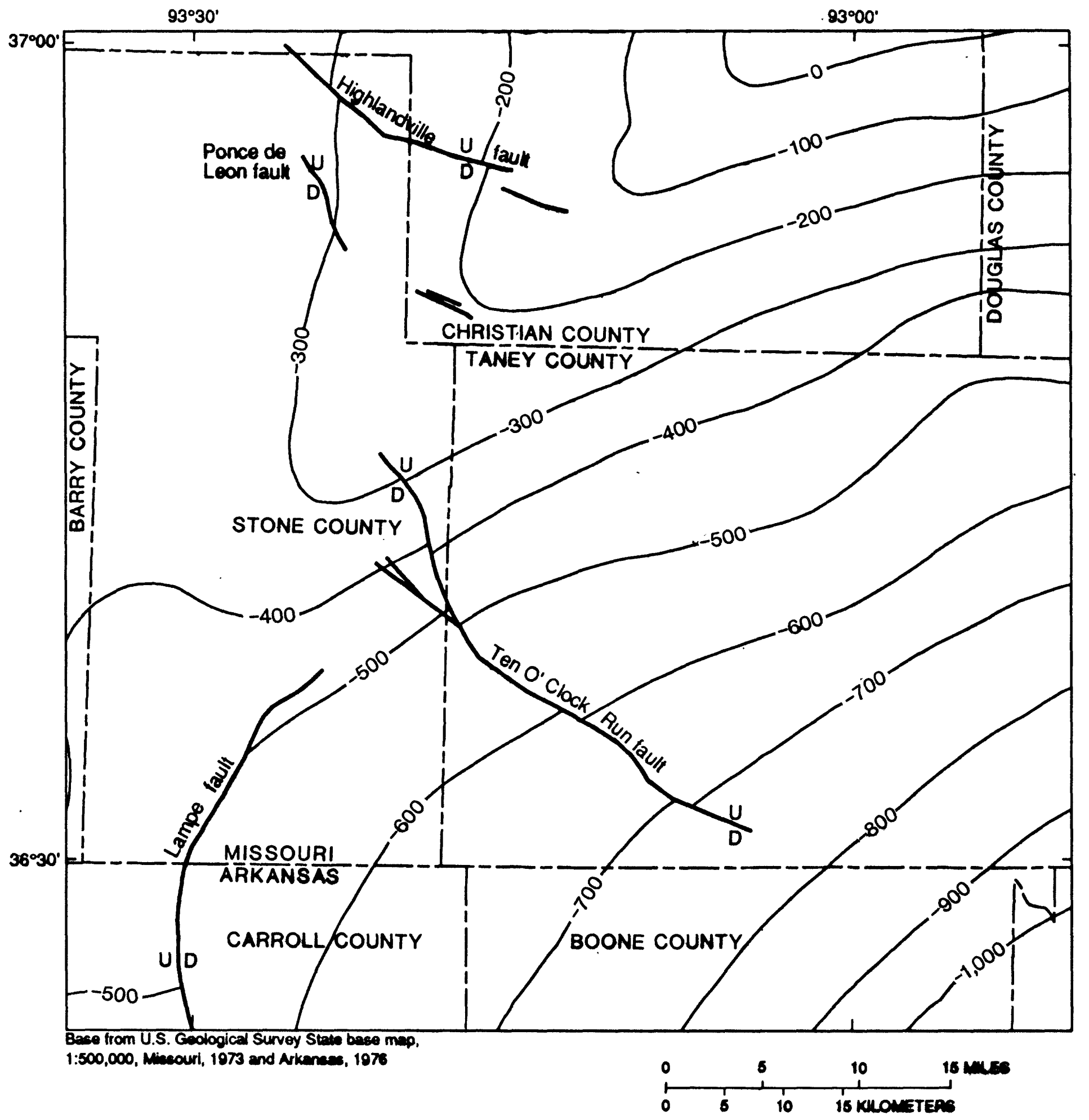

\section{EXPLANATION}

- -500 - BASE OF LOWER ZONE OF OZARK AQUIFER--Shows altitude of base of lower zone of Ozark aquiter. Interval is 100 feet. Datum is sea bvel

$\frac{U}{D}$ FAULT.-U. upthrown side; D. downthrown side

Fiqure 6.--Altitude of the base of the lower zone of the Ozark aquifer (modified from Imes, 1000a). 


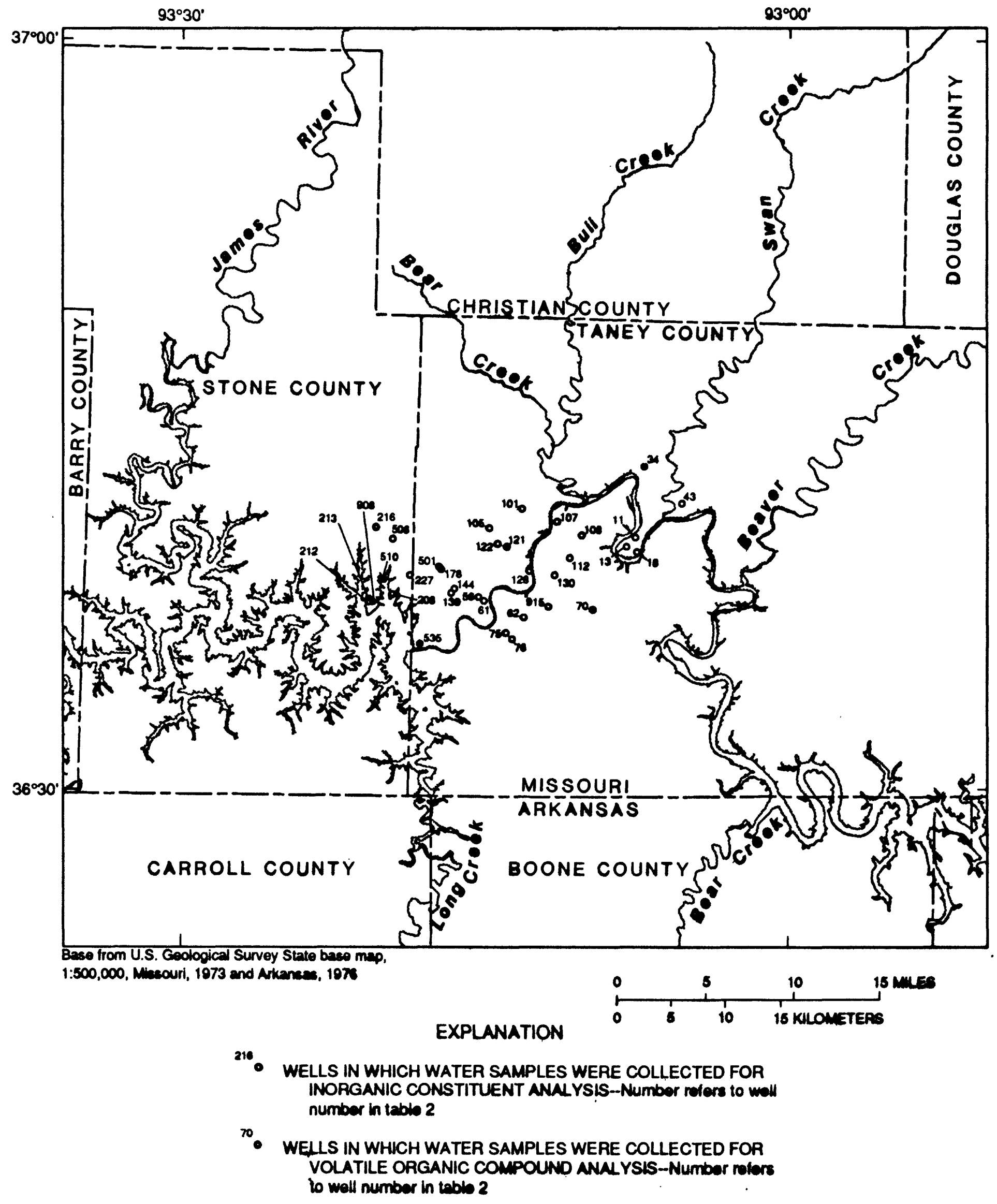

Figure 7.--Location of wells in which water-quality samples were collected and analyzed tor selected inorganic constituents and volatile organic compounds. 


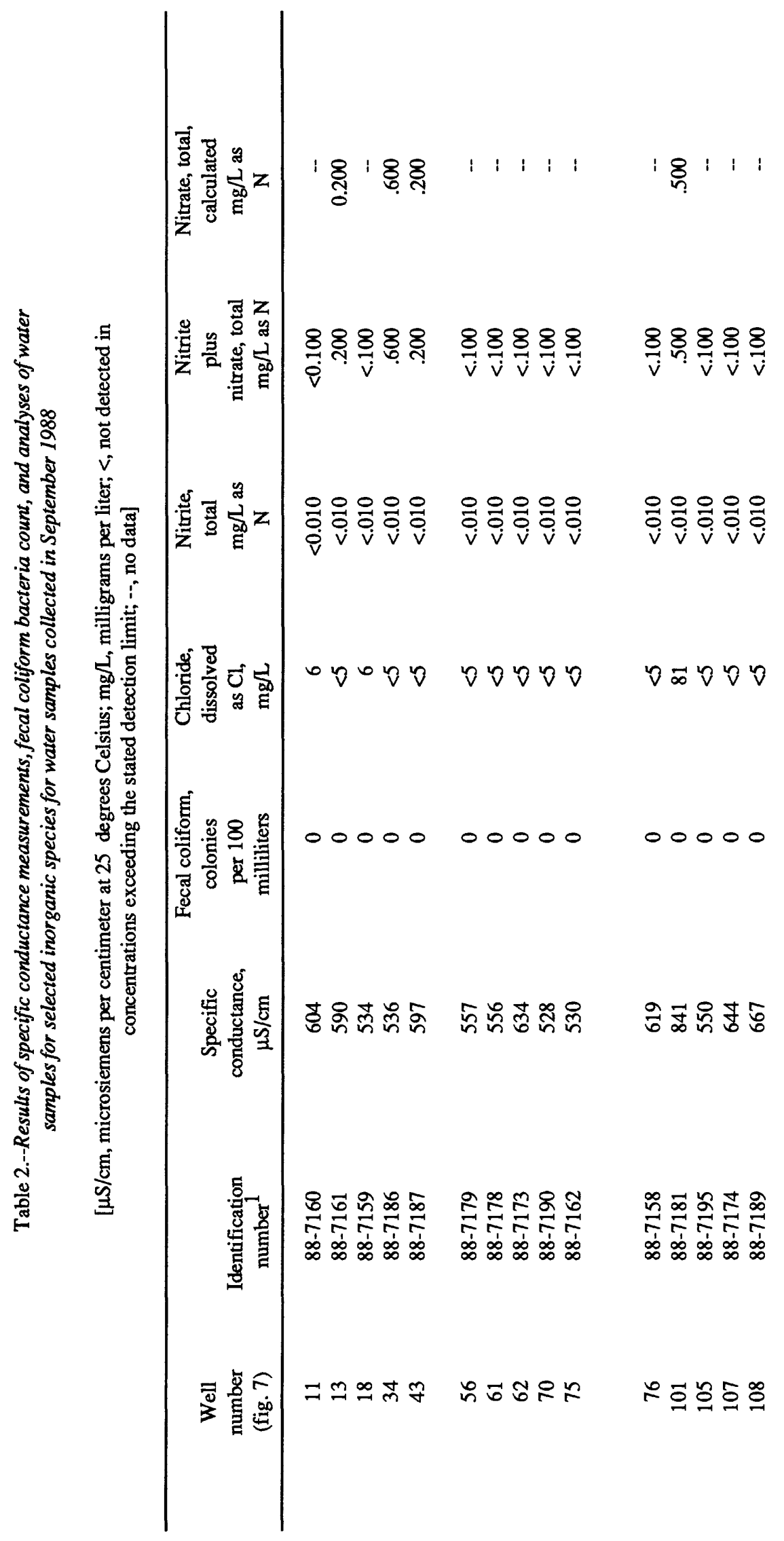




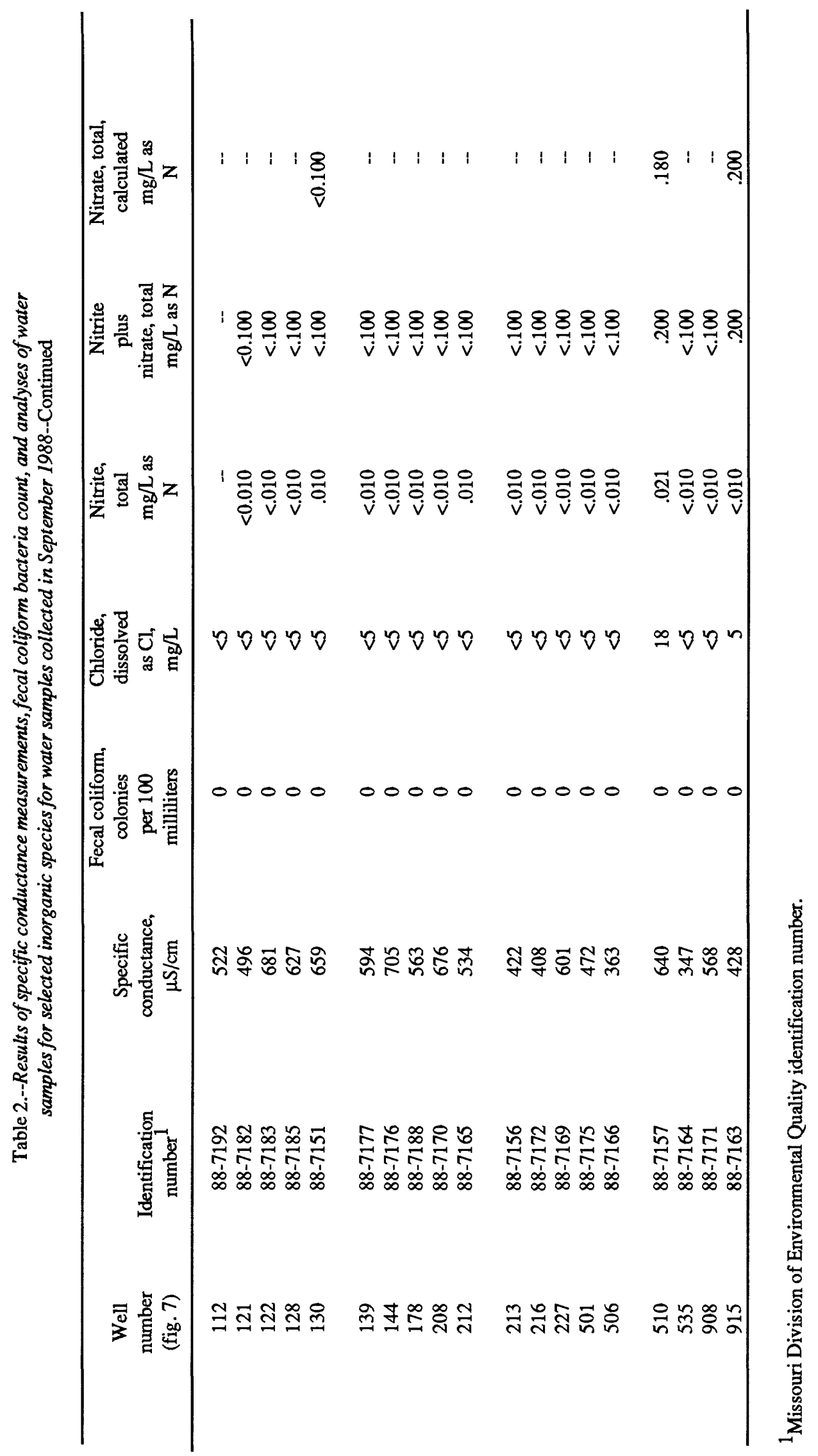


In addition to analyzing ground-water samples for inorganic species, samples from five wells (fig. 7) were analyzed for selected volatile organic constituents. None of the analyses detected the presence of any of the 33 volatile organic compounds in excess of the detection limits for the compounds (table 3 ).

\section{Water Levels in the Ozark Aquifer}

Before construction of Table Rock Lake, Lake Taneycomo, and Bull Shoals Lake, the predevelopment potentiometric surface of the upper zone of the Ozark aquifer was primarily controlled by local topographic relief (fig. 8). Ground water generally flowed from upland recharge areas to discharge areas along the major streams, especially the White and James Rivers. Ground-water levels in the upper zone were as high as $1,200 \mathrm{ft}$ atop a long narrow divide between the James River and Bull Creek. The lowest ground-water levels were along the White River valley, decreasing downstream from about $800 \mathrm{ft}$ at the western boundary of the study area to less than $600 \mathrm{ft}$ at the eastern boundary. Most of the available predevelopment hydraulic-head data are for western Taney and northern Stone Counties. Contour lines in figure 8 outside of these two areas are drawn to conform to topographic relief and streambed altitude data.

Insufficient data exist to construct a contour map of the predevelopment potentiometric surface of the lower zone of the Ozark aquifer. Water-level data from the late 1940's and 1950's are available for the lower zone near Branson (Brown, 1988); however, these data appear to reflect drawdown conditions. Two predevelopment water levels, one measured in 1926 and the other in 1942, indicate water levels in the lower zone along the White River valley near Branson were higher than water levels in the White River (Brown, 1988). Water-level measurements in two wells located near each other in east-central Christian County (one well open to the upper zone and one well open to the lower zone) indicate a downward gradient (Brown, 1988). Water levels in this area in the lower zone probably are about $20 \mathrm{ft}$ lower than water levels in the upper zone. These measurements are consistent with concepts of ground-water flow that regard the White River as a major regional discharge area for ground water recharging upland areas in southern Missouri and northern Arkansas (Imes and Emmett, in press).

Water-level data (table 4 and fig. 9) collected in summer 1987, June-July 1988, March 1989, and June-July 1989 were available for this project. The data were compared directly, where water levels were measured in the same wells at different times, and indirectly, by constructing potentiometric contour maps, to determine water-level changes in the Ozark aquifer caused by seasonal changes in ground-water withdrawal rates. Water-level measurements for the summer of 1987 , before this project began, were made in Missouri by the Missouri Division of Geology and Land Survey (Brown, 1988). Water-level data (1987) tabulated for Arkansas are part of data entered into the U.S. Geological Survey Ground-Water Site Inventory file at Little Rock, Arkansas. Three synoptic water-level measurements were made as part of this project; one in 1988 and two in 1989.

It proved possible to divide the water-level data into two distinct groups based on the geologic formations to which the wells are open. The two groups, wells open primarily to the Cotter and Jefferson City Dolomites and wells open primarily to the Roubidoux-Potosi sequence of formations, indicate that a well-defined hydraulic gradient exists between the upper and lower zones of the Ozark aquifer in the Branson area.

By summer 1987, ground-water levels in the upper zone near Branson indicated the effect of water withdrawals from the Ozark aquifer (fig. 10). A generalized broad, shallow, drawdown cone, encompassing the area around Branson and Hollister, is evidenced by the $700-\mathrm{ft}$ contour line. The $800-$ $\mathrm{ft}$ potentiometric contour extends farther west of Branson than under predevelopment conditions because of the westward expansion of Branson and its water-supply system from the shore of Lake Taneycomo. The connection of the $800-\mathrm{ft}$ contour across Lake Taneycomo southwest of Branson in Taney County is caused by the increased hydraulic head that followed the creation of Table Rock Lake, 
Table 3.--Well information, volatile organic compounds, and detection limits for water samples collected in September 1988

[Well information consists of the following: top number-well number; bottom number-Missouri Department of Natural Resources, Division of Environmental Quality identification number; detection limits are in micrograms per liter; no volatile organic compound was detected in excess of the detection limit]

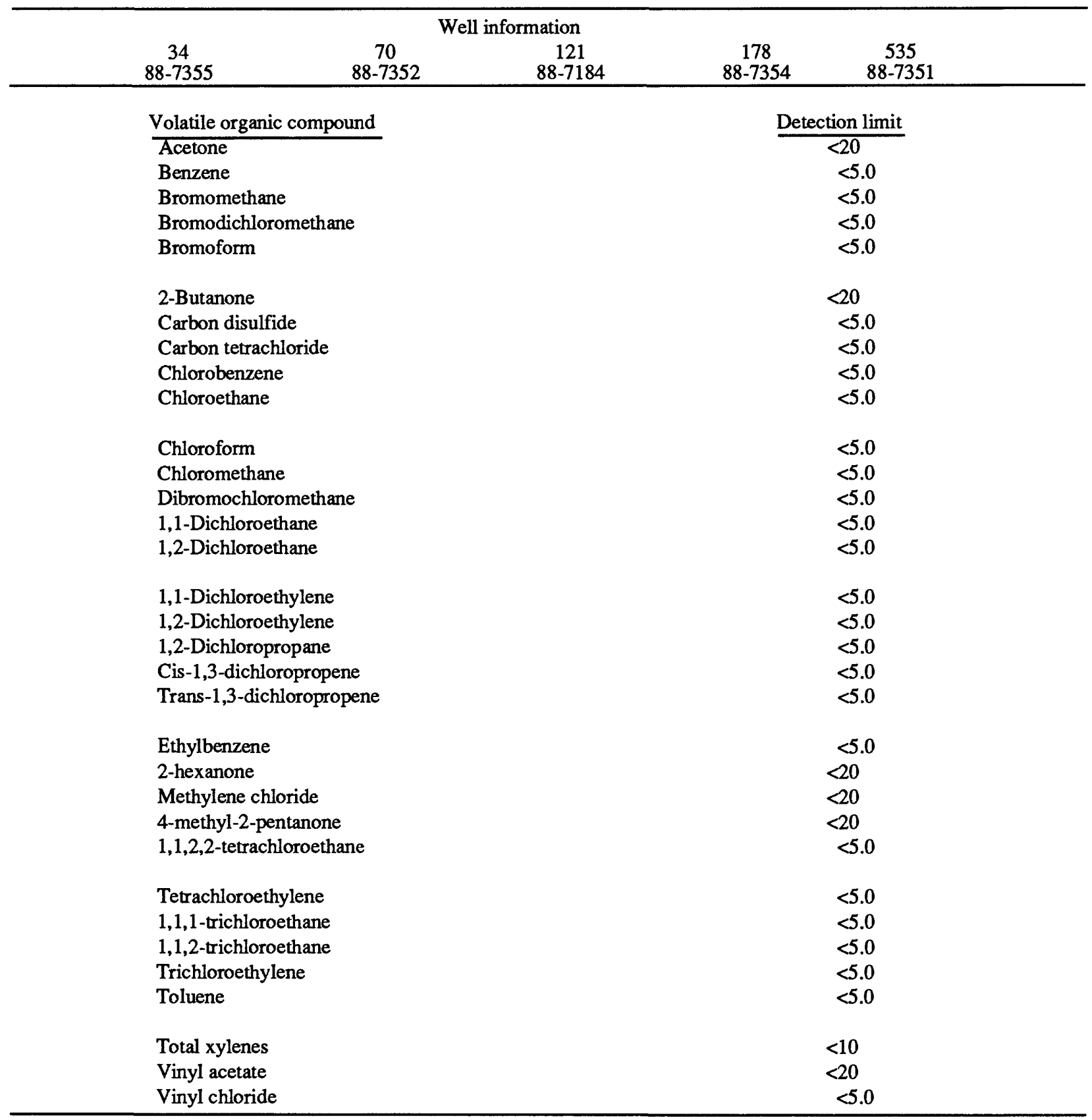




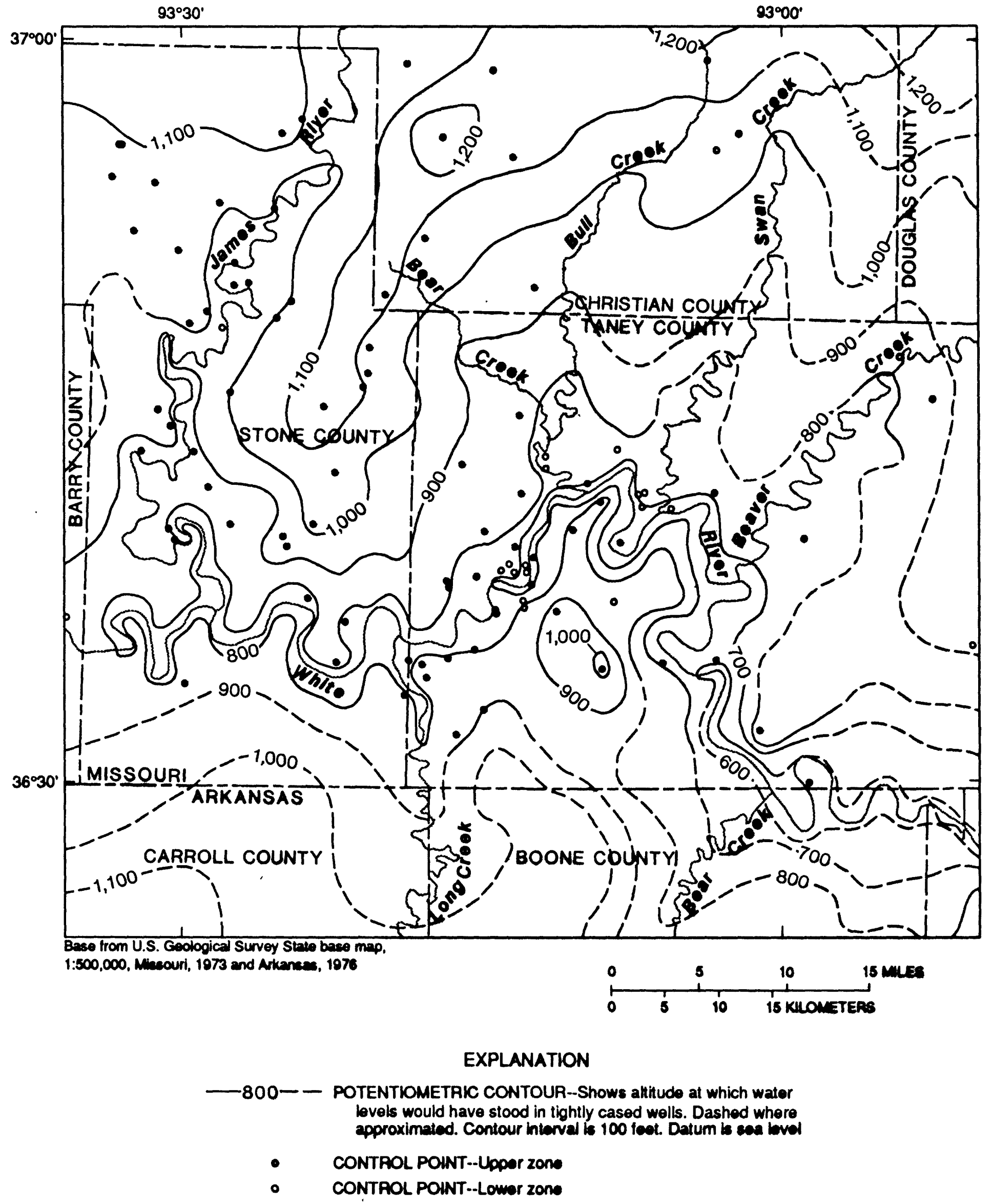

Figure 8.--Predevelopment potentiometric surface of the upper zone of the Ozark aquiler. 


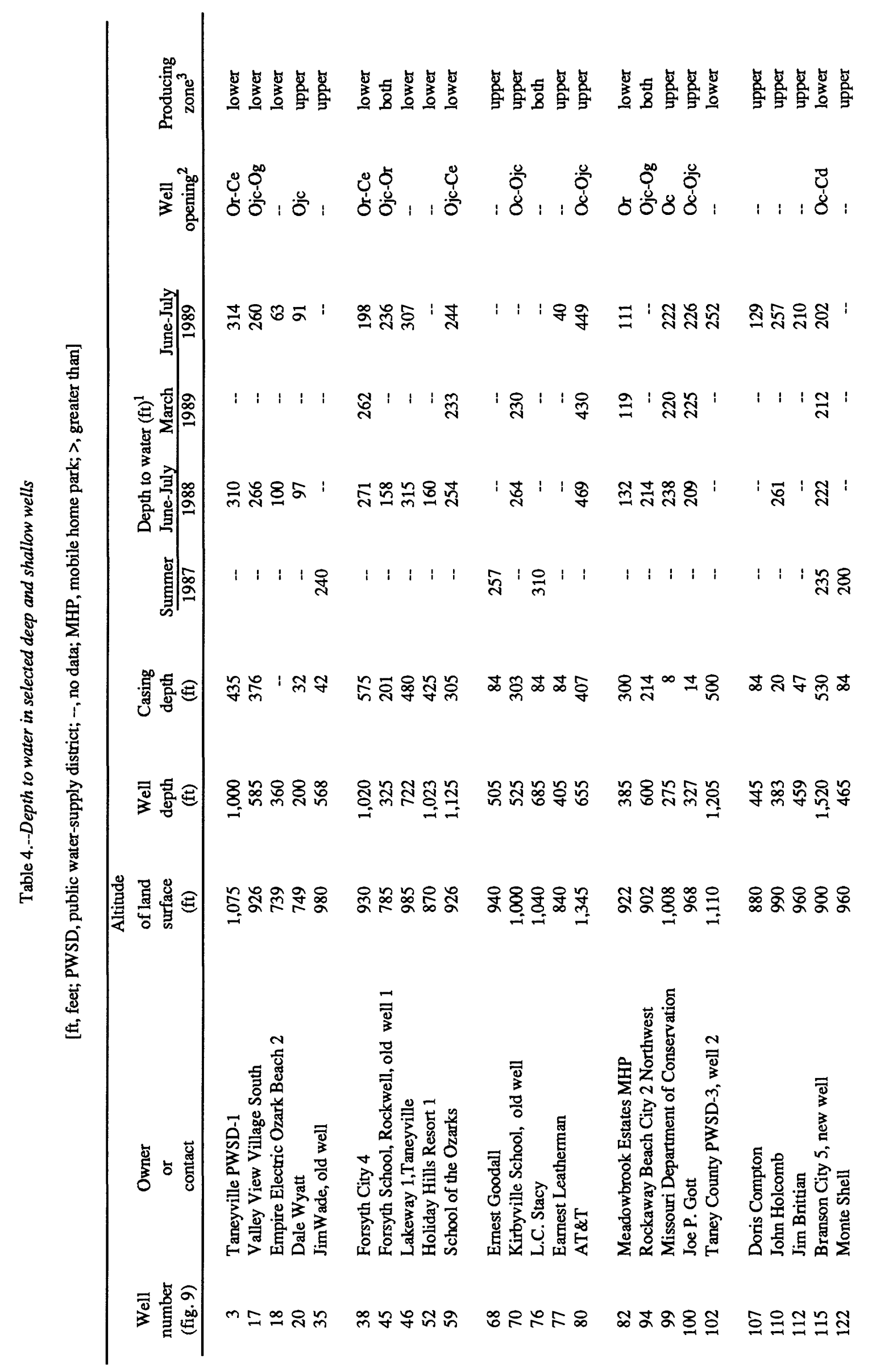




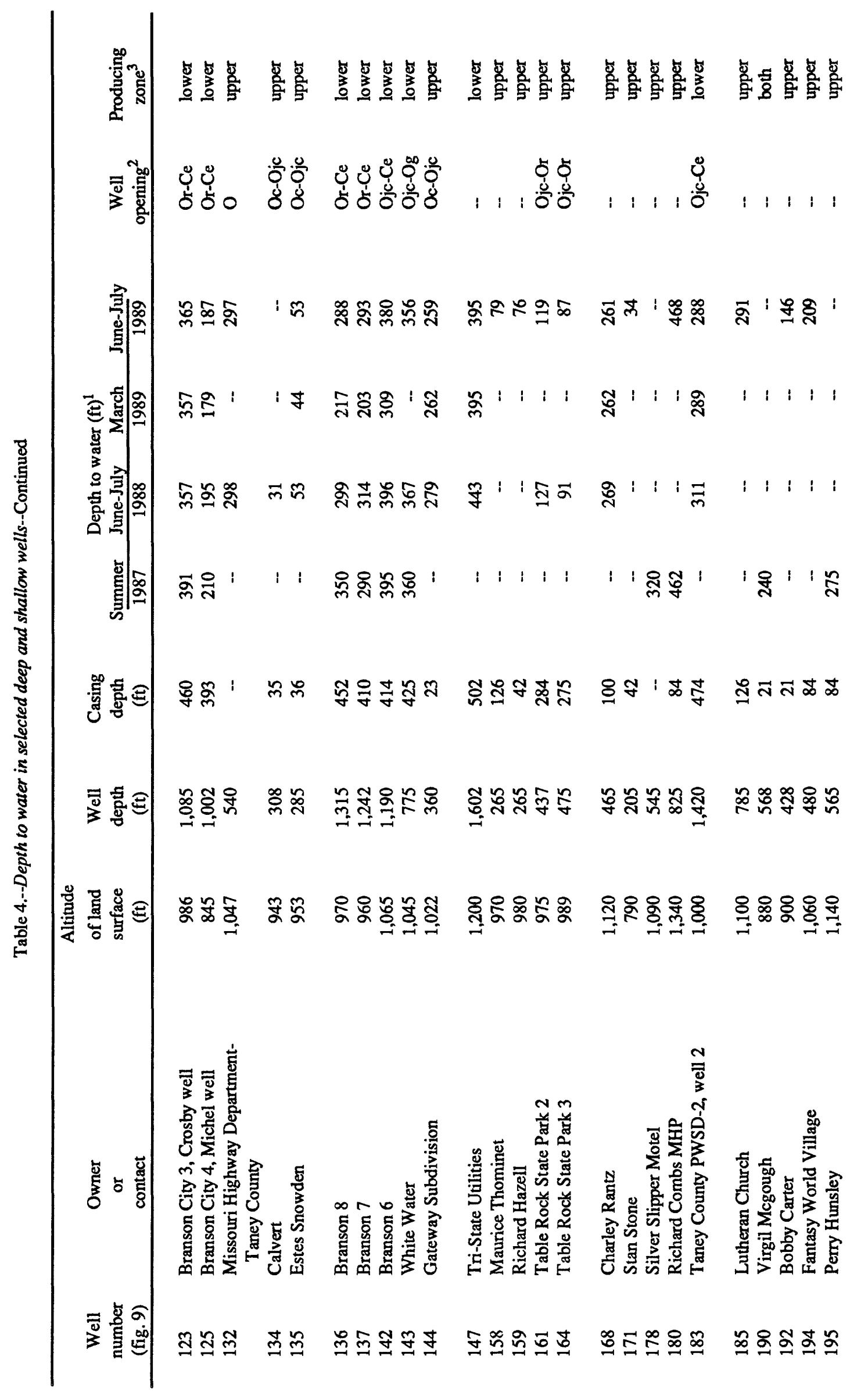




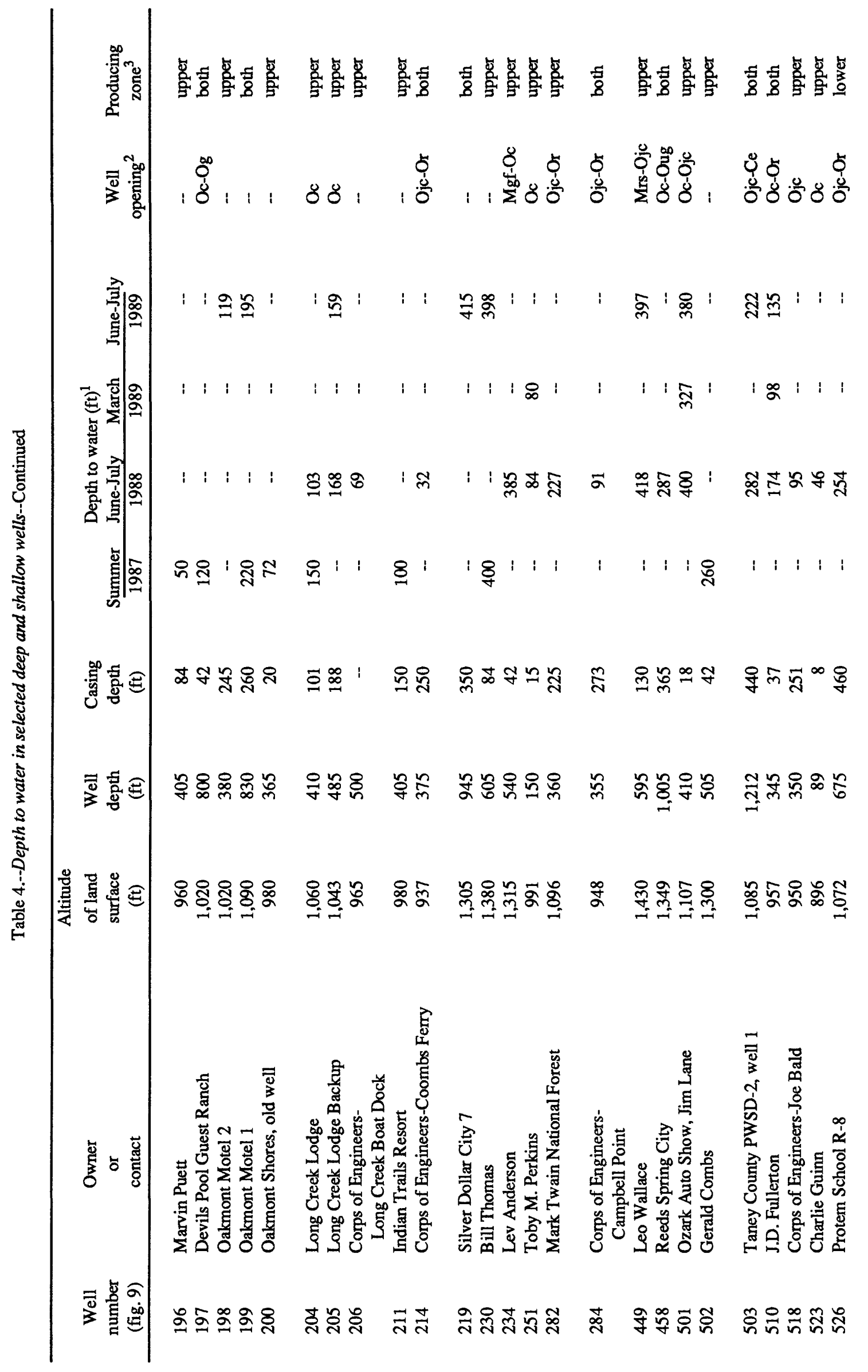




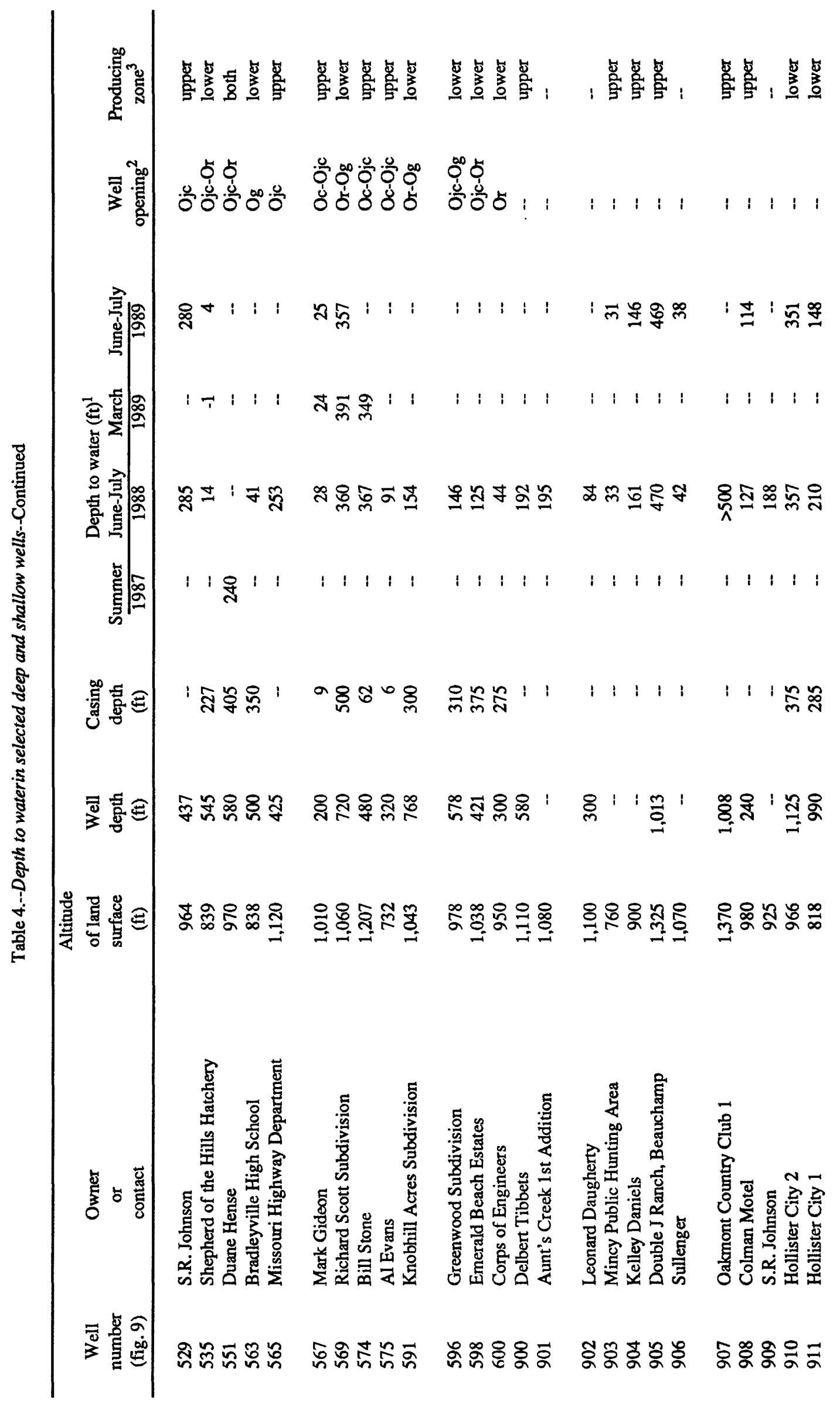




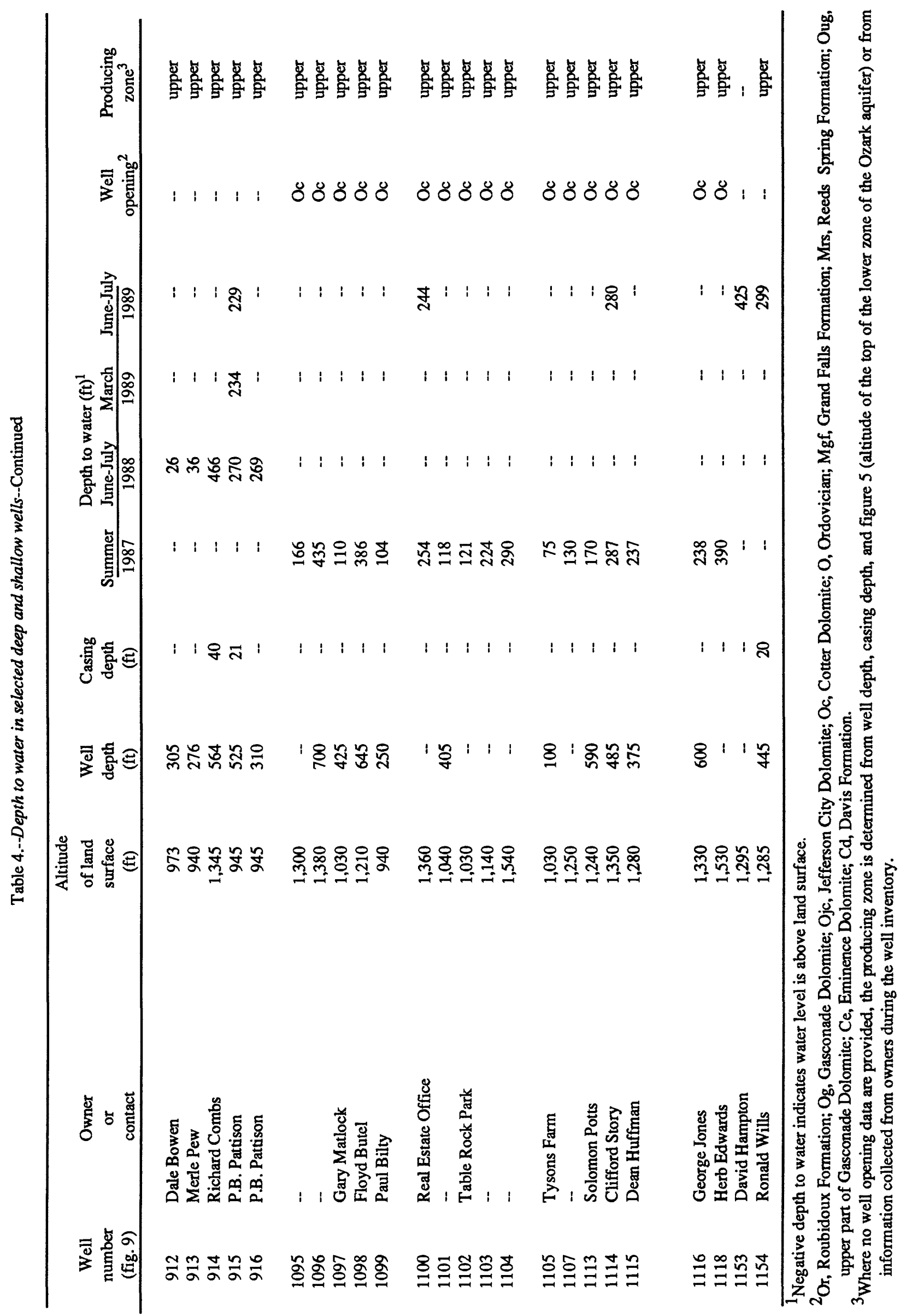




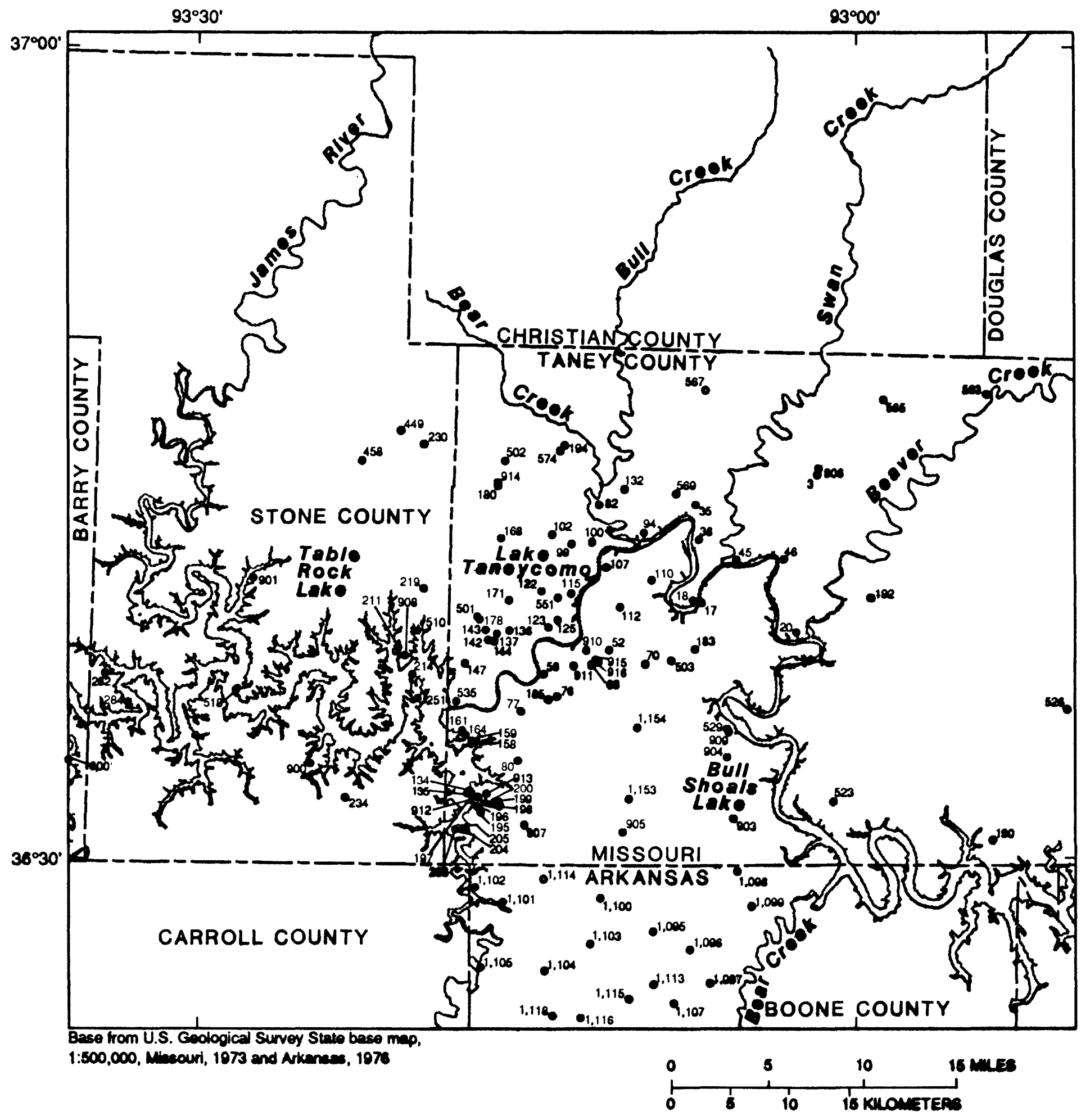

\section{EXPLANATION}

910 WELLS IN WHICH WATER-LEVELS WERE MEASURED AND REPORTED IN TABLE 4--Four wolls located at the western end of Table Rock Lake are not shown. Number refers to woll number in table 4 . Wells 125 and 144 are continuous water-bvel monitoring wolls

Figure 9.--Location of wells in which water levels were measured and reported in table 4 and location of water-bevel monitoring wells. 


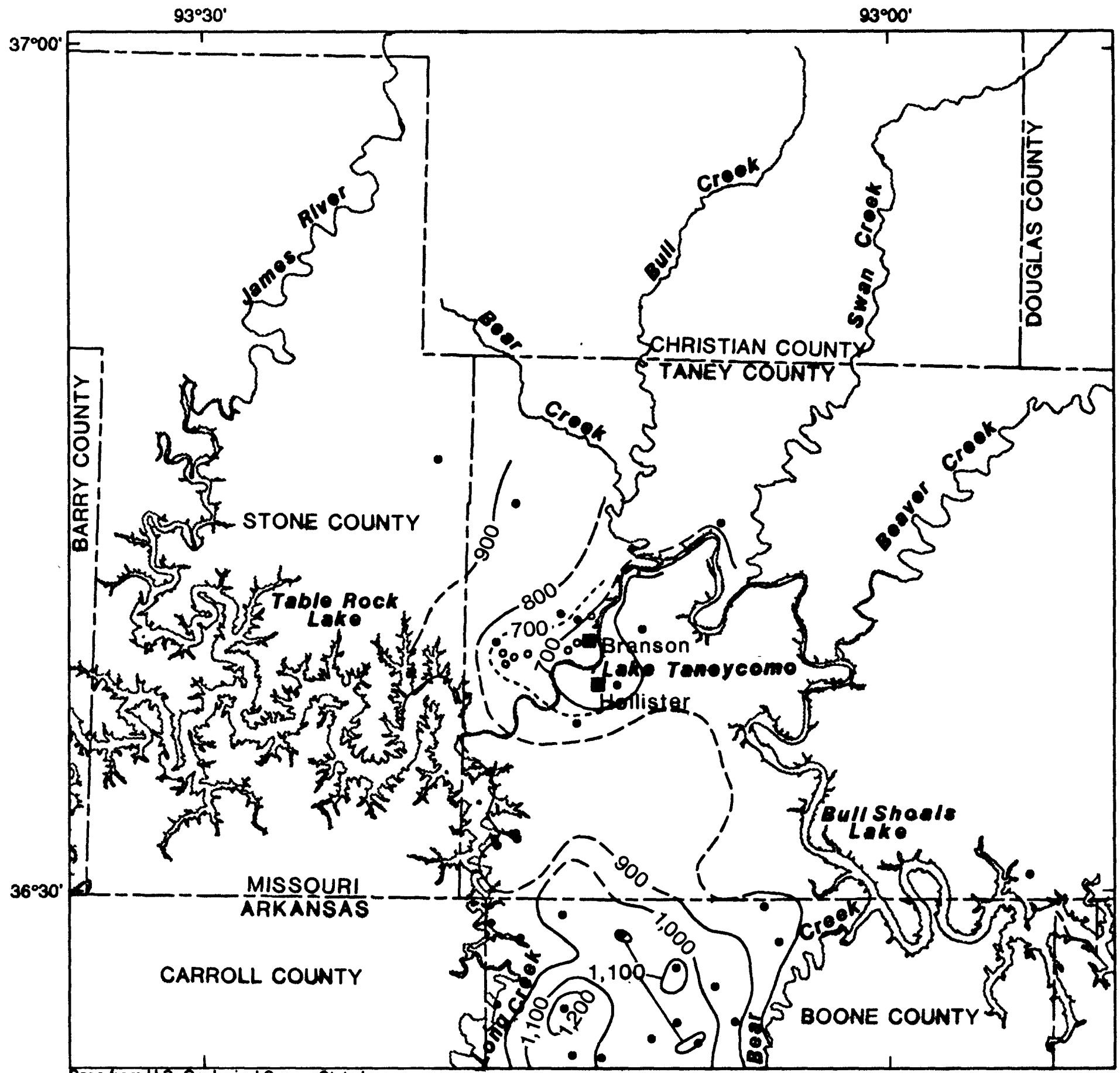

Bese trom U.S. Geological Survey Stalo bace map. 1:500,000, Miecouri, 1973 and Arkanes, 1976

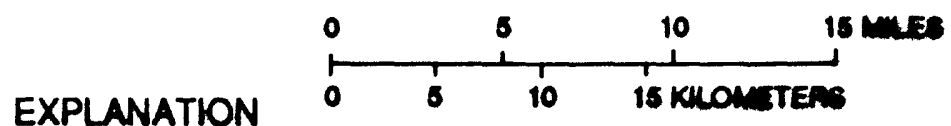

\section{EXPLANATION}

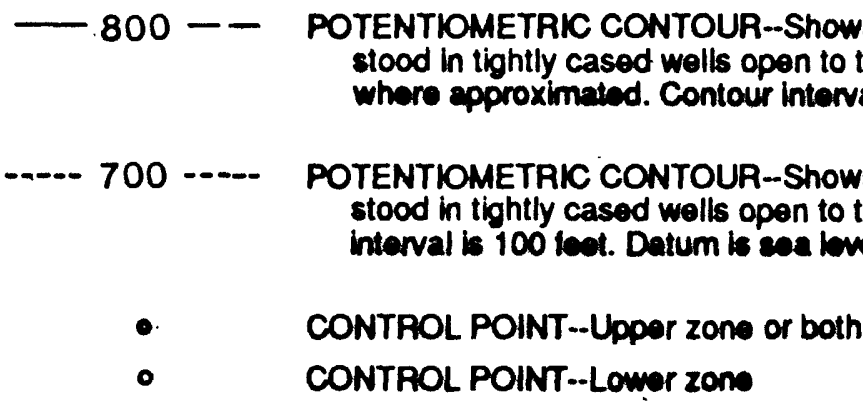

Figure 10.--Potentiometric surface of the upper and bwer zones of the Ozark aquifer, summer 1987. 
not from hydraulic head changes induced by water-supply wells in the Branson area. The shape and magnitude of the drawdown cone indicates that the upper zone is not well-connected hydraulically to Lake Taneycomo.

The extent and depth of the drawdown is even greater in the lower zone of the Ozark aquifer. The $700-\mathrm{ft}$ potentiometric contour of the lower zone extents farther west than its counterpart in the upper zone and envelopes newer water-supply wells at the western edge of Branson. The water-level altitude at the point of maximum drawdown as determined from the measured water levels is $595 \mathrm{ft}$ and occurs in well 123 (Branson "Crosby" well). The fact that the drawdown in the lower zone is substantially greater than the drawdown the upper zone is a reflection of the fact that most large-capacity watersupply wells in the Branson area withdraw water from the lower zone.

The first synoptic water-level measurements conducted by the U.S. Geological Survey as part of this project occurred in June-July of 1988 during the peak of the tourist season. Water levels in 77 wells open to the Ozark aquifer were measured at this time. A comparison of eight water levels measured in the same wells in the summer of 1987 and summer of 1988 indicates that water levels increased in five wells and decreased in three wells. It is difficult to make meaningful conclusions about the summer 1987 to summer 1988 water-level changes because no water-use data are available to relate changes in water levels to changes in water-use patterns. No large changes in water levels near Branson from the summer of 1987 (fig. 10) to the summer of 1988 (fig. 11) are apparent in the potentiometric surface of the upper zone, except in the area north of Table Rock Dam. Water levels in the lower zone seem to have declined near Hollister, but the apparent decline may be caused by the additional data collected in the summer of 1988. There is no evidence that substantial changes in water levels from predevelopment conditions have occurred beyond the vicinity of Branson and Hollister.

Water levels in 26 wells were measured in March 1989, during the winter period of reduced water demand. A comparison of water levels measured in June-July 1988 and late March 1989 indicates water levels increased in 23 wells, decreased in 2 wells, and remained the same in 1 well (table 4). Water-level increases in the 23 wells ranged from 4 to $111 \mathrm{ft}$, with the larger increases occurring in the city of Branson municipal wells. This is most evident in the much smaller area encompassed by the drawdown cone around Branson at the 700-ft contour line for the lower zone potentiometric surface in March 1989 (fig. 12) as compared to June-July 1988 (fig. 11). The relatively large number of wells in which water levels increased from the summer of 1988 to the winter of 1989 probably results from the generally decreased rate of water use between the summer tourist seasons.

The last synoptic water-level measurement occurred in June-July 1989 and where comparisons could be made, water levels in the 64 measured wells generally decreased from the previous winter, reflecting increased water demand during the summer tourist season. Of 23 wells common to both the March 1989 and June-July 1989 mass water-level measurements, water levels in 14 wells decreased, water levels in 1 well remained unchanged, and water levels in 8 wells increased (table 4). Four of the wells having the largest water-level declines (more than $50 \mathrm{ft}$ ) are located in Branson. Water levels in 6 of the 8 wells that showed an increase rose $10 \mathrm{ft}$ or less. The remaining two wells (38 and 569), which showed water levels increasing by more than $30 \mathrm{ft}$, supply water to a subdivision and the city of Forsyth. The June-July 1989 potentiometric surfaces for both the upper and lower zones of the Ozark aquifer (fig. 13) show increased drawdown from March 1989 (fig. 12) near Branson. Water levels measured in 45 wells in June-July 1988 and June-July 1989 indicate that water levels rose in 40 wells, remained the same in 1 well, and declined in 4 wells (table 4). Comparison of the water-level measurements and the potentiometric surfaces in the upper and lower zones in June-July 1988 (fig. 11) and June-July 1989 (fig. 13) indicates that water levels in the Ozark aquifer near Branson are not experiencing continuous long-term declines, but are adjusting rather rapidly to seasonal water-use demand. Because water-use data collection was not initiated until September 1988, it is not possible to directly correlate changes in water levels from the summer of 1988 to the summer of 1989 to changes in water-use patterns. 


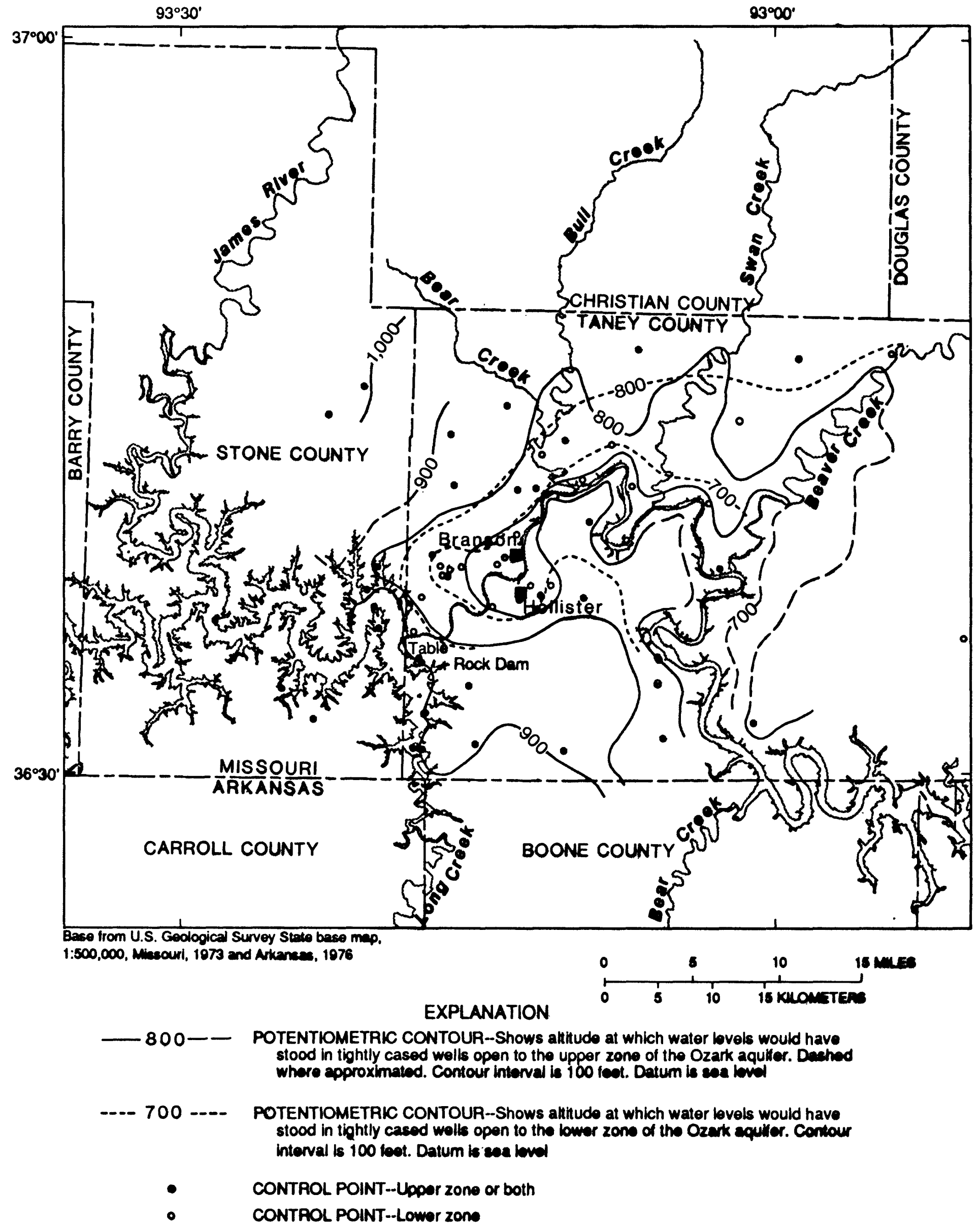

Figure 11.--Potentiometric surface of the upper and bwer zones of the Ozark aquifer, June-July 1898. 


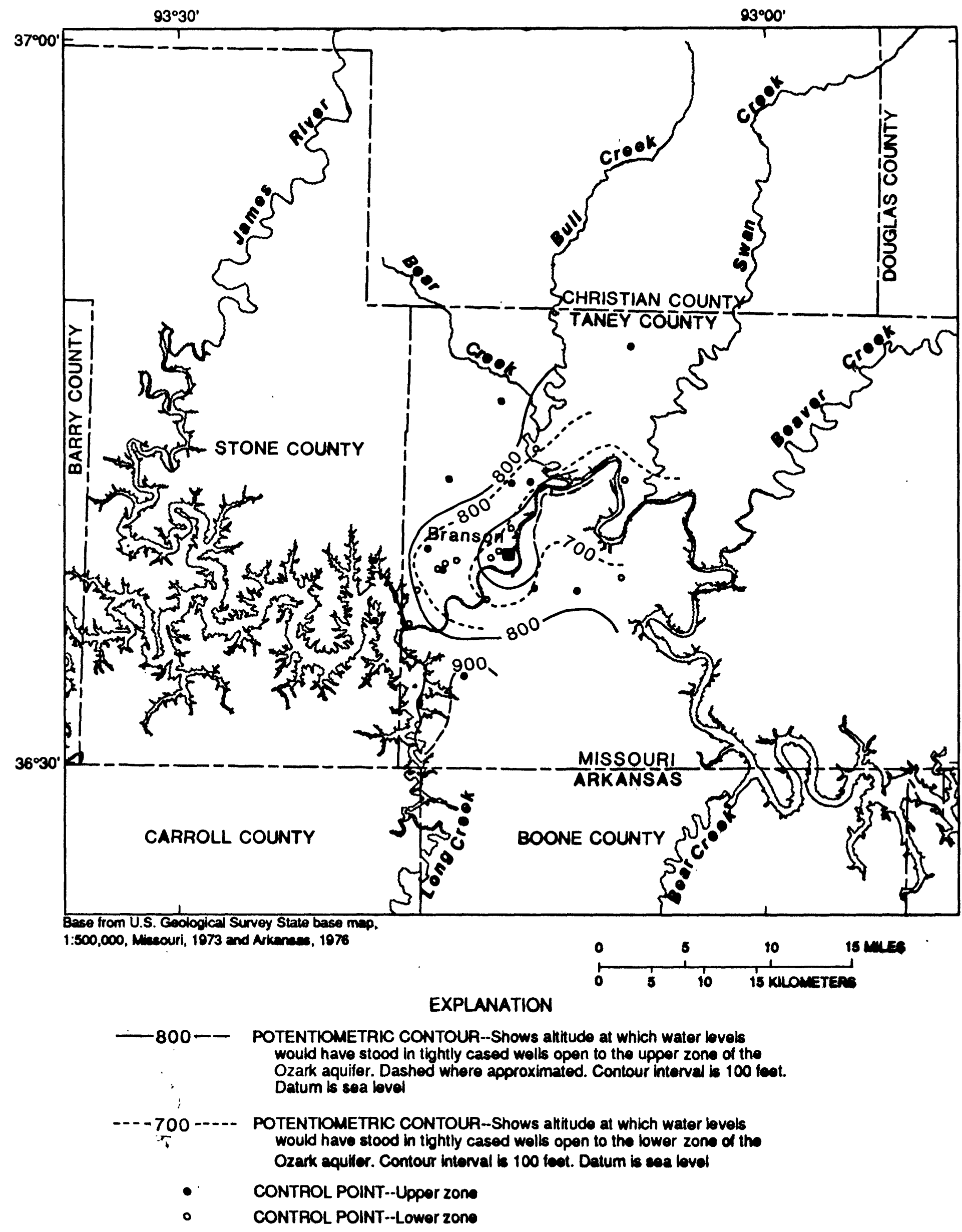

Figure 12.--Potentiometric surface of the upper and bwer zones of the Ozark aquifer, March 1989. 


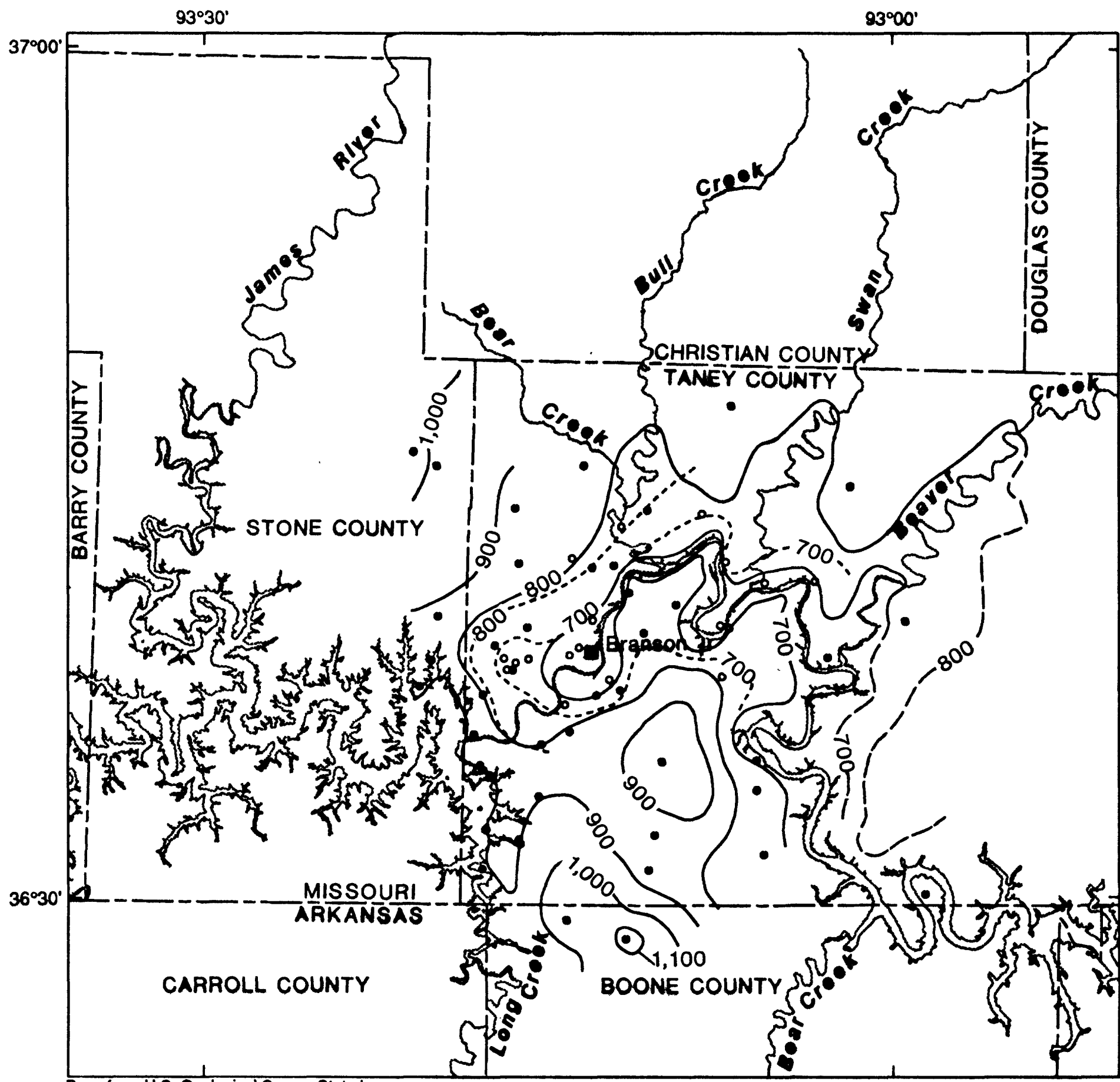

Base from U.S. Geological Survey State base map. 1:500,000, Nisecuri, 1073 and Akemaec, 1076

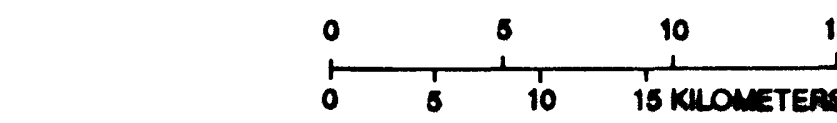

$18 \mathrm{mins}$

EXPLANATION

$-800-1$ POTENTIOMETRIC CONTOUR--Shows altitude at which water bvels would have stood in tightly cased wells open to the upper zone of the Ozark aquifer. Deaned where approximated. Contour interval is 100 foet. Detum is cea law

-.-1-700 -.-- - POTENTIOMETRIC CONTOUR--Shows altitude at which water bevels would have stood in tightly cased wolls open to the lower zone of tho Ozark aquiter. Contour interval is $100 \mathrm{fect}$. Datum is sea bvel

- CONTROL POINT--Upper zone or both

- CONTROL POINT--Lower zone

Figure 13.--Potentiometric surface of the upper and bwer zones of the Ozark aquifer, June-July 1989. 


\section{Water-Level Monitoring}

From the inception of this project, it was determined that several wells in the study area would need to be monitored on a regular basis to provide information on the seasonal fluctuations of water levels in the Ozark aquifer. After completion of a well inventory and the first synoptic water-level measurements in the summer of 1988 , seven wells were selected as candidates for water-level monitoring wells. Permission to measure water levels intermittently could be obtained for only two wells open to the lower zone; wells 59 (School of the Ozarks) and 125 (Branson, "Michel" well), and one well open to the upper zone, well 144 (Gateway subdivision). Access was not obtained to use paired shallow and deep wells to monitor differences in hydraulic head between the upper and lower zones of the Ozark aquifer. The city of Branson intended to monitor water levels in the three wells beginning in late September 1988, but decided not to monitor well 59 and postponed monitoring well 144 until March 1989 (fig. 9).

Hydrographs of water-level data for wells 125 and 144 are presented in figure 14. Water levels in well 125 rose $21 \mathrm{ft}$ from late September 1988 to early December 1988 and remained stable from December 1988 through March 1989. At the onset of warm weather, and coinciding with the opening of business establishments that serve the tourist industry, water levels in the lower zone of the Ozark aquifer begin to decline. The lowest water level in 1989 in well 125 occurred in September. Depth to water measurements in well 144 ranged from 256 to $268 \mathrm{ft}$ and does not display any discernible seasonal pattern. Thus, the water-level changes in well 125 apparently were caused by changing rates of pumping, not by seasonal changes in precipitation.

\section{Water Use by Municipalities, Public Water-Supply Districts. And Selected Businesses}

Because it is necessary to have accurate water-use data to properly calibrate a ground-water flow model, the principal users of ground water were contacted in September 1988 and requested to measure their water-use rate on a monthly basis for the duration of the project. Monthly water-use information collected through February 1990 is listed in table 5 and the location of the wells containing large-capacity pumps is shown in figure 15. The largest user of ground-water in the study area is the city of Branson. The combined pumping rate of all Branson municipal wells ranges from about 20 to 25 million gallons per month in mid-winter to about 50 million gallons per month in mid-summer. Other water users pump less water, but generally show a similar pattern of increasing pumping rates in the summer.

\section{SIMULATION OF GROUND-WATER FLOW NEAR BRANSON}

Ground-water flow in the upper and lower zones of the Ozark aquifer was simulated using a modular three-dimensional finite-difference model (McDonald and Harbaugh, 1984). The variablegrid model contains 54 rows by 55 columns centered on Branson with cell sizes ranging from 0.5 mi by $0.5 \mathrm{mi}$ near the center of the model to $2 \mathrm{mi}$ by $2 \mathrm{mi}$ near the corners of the model (fig. 16). The variable cell size of the model design permits a detailed analysis of flow near Branson without requiring that a large quantity of data be collected in the outlying areas of lesser interest to this study. Three distinct groups of water-bearing rocks are represented by active model layers (fig. 17) for which hydraulic-head distributions are calculated; the Springfield Plateau aquifer (layer 1), the upper zone of the Ozark aquifer (layer 2), and the lower zone of the Ozark aquifer (layer 3). Passive layers, for which hydraulichead distributions are not calculated, are used to represent less-permeable material between the centerlines of the aquifers and aquifer zones. The leakage coefficient between each active layer was calculated independent of the model and includes the effect of the less-permeable material between the active layers and the vertical anisotropy within each active layer. 


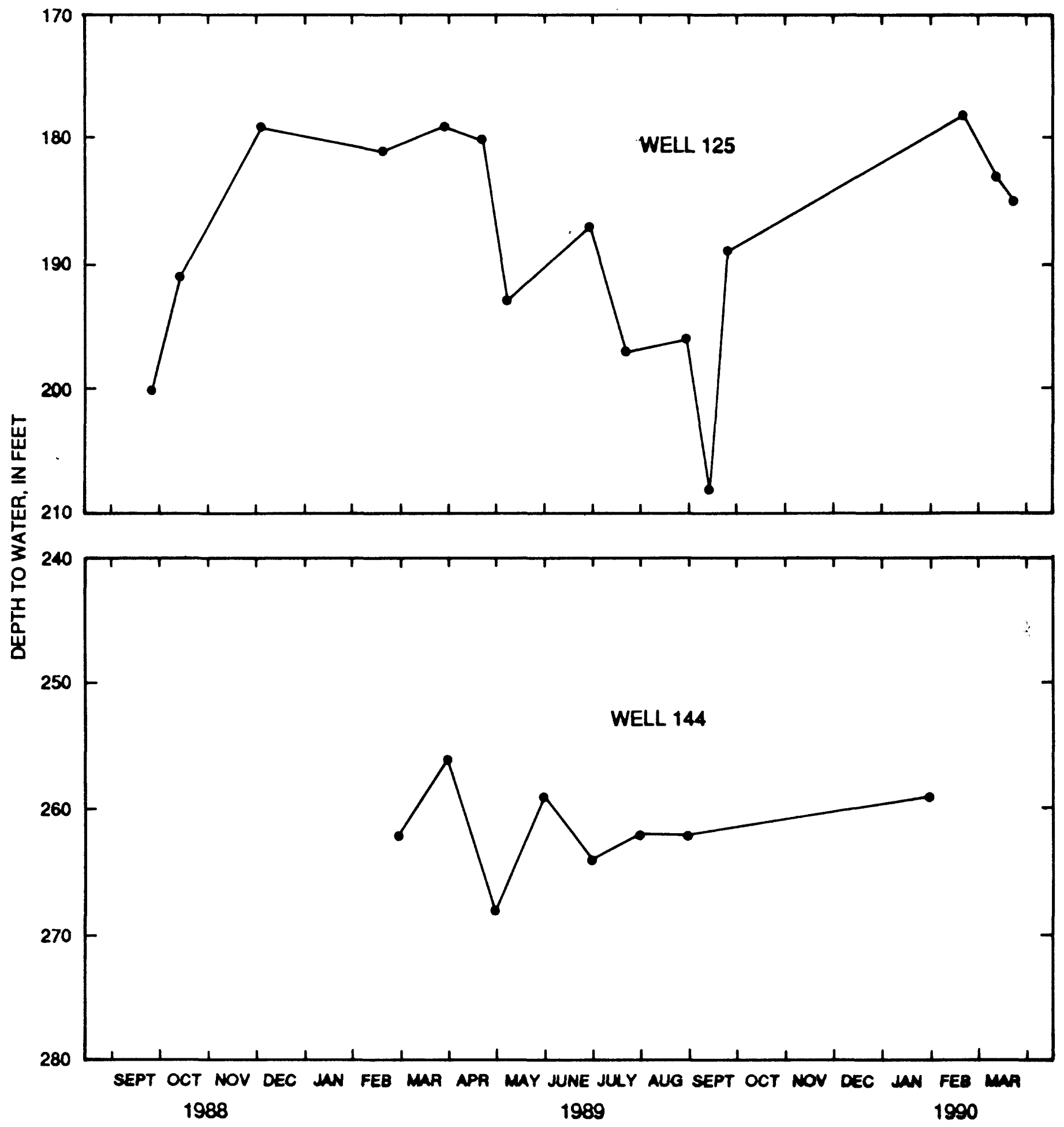

Figure 14.--Water levels in well 125 (City of Branson "Michol" Well) and well 144 (Gateway subdivision). 


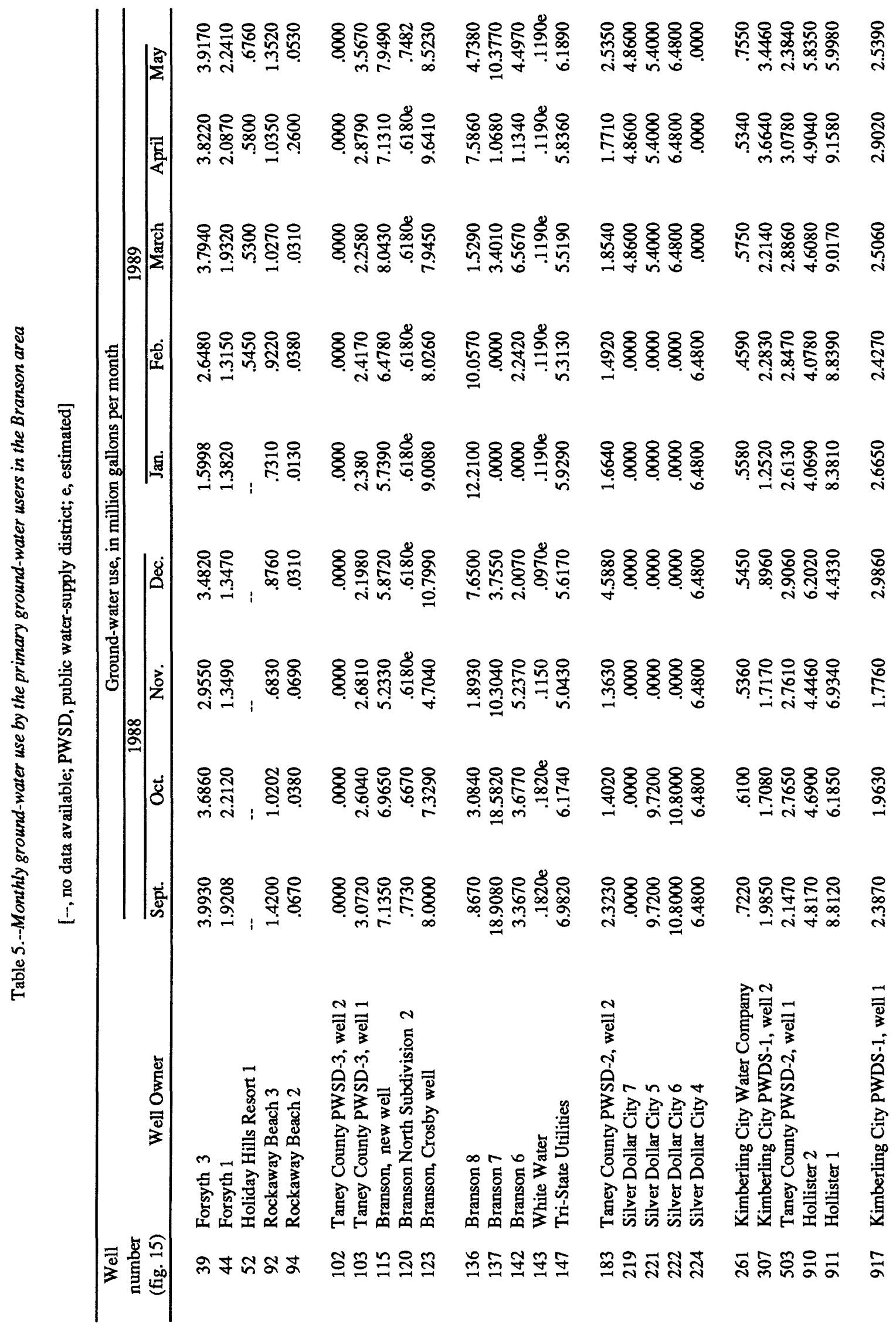









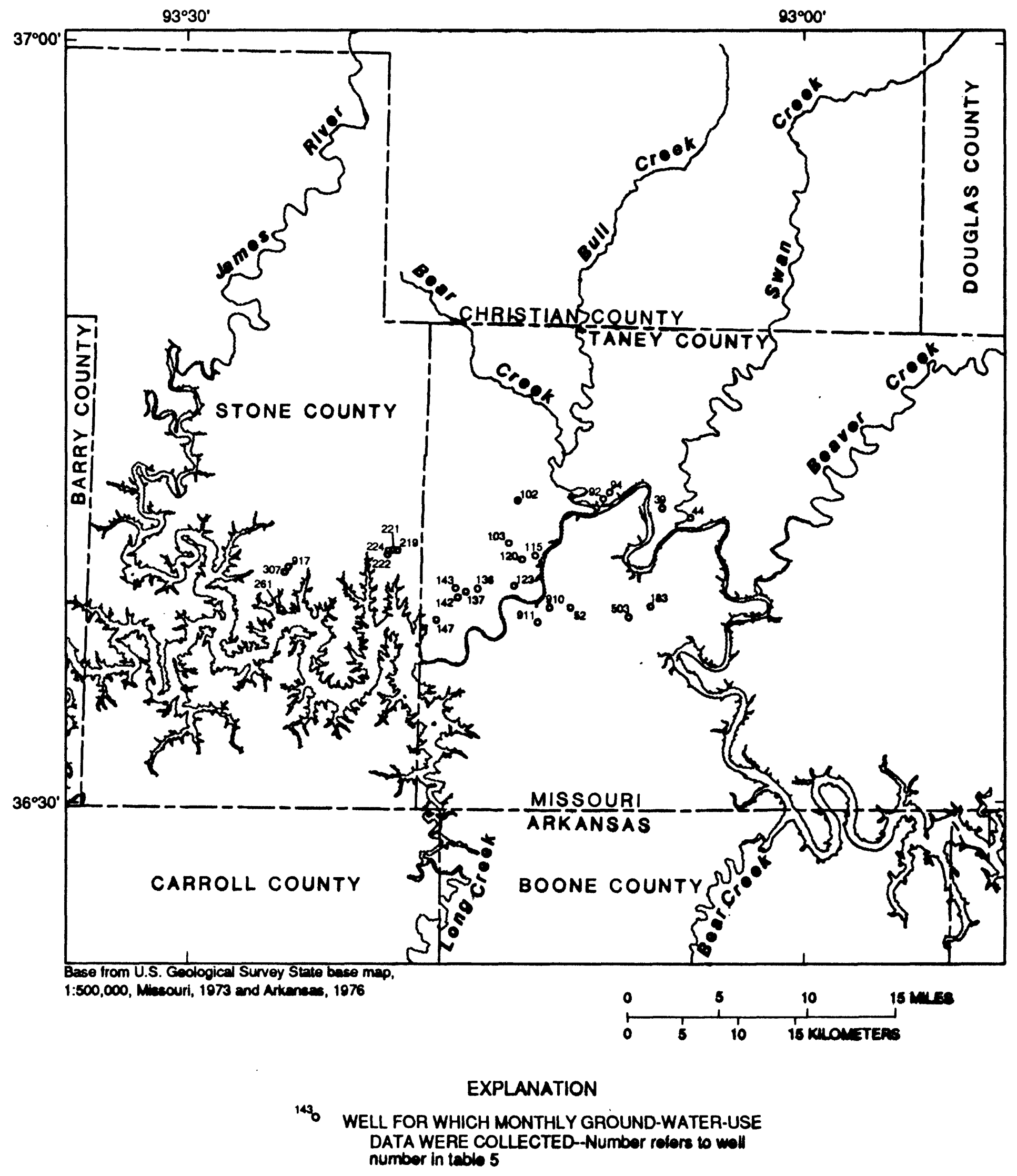

Figure 15.--Location of wells for which monthly ground-water-use data were collected. 


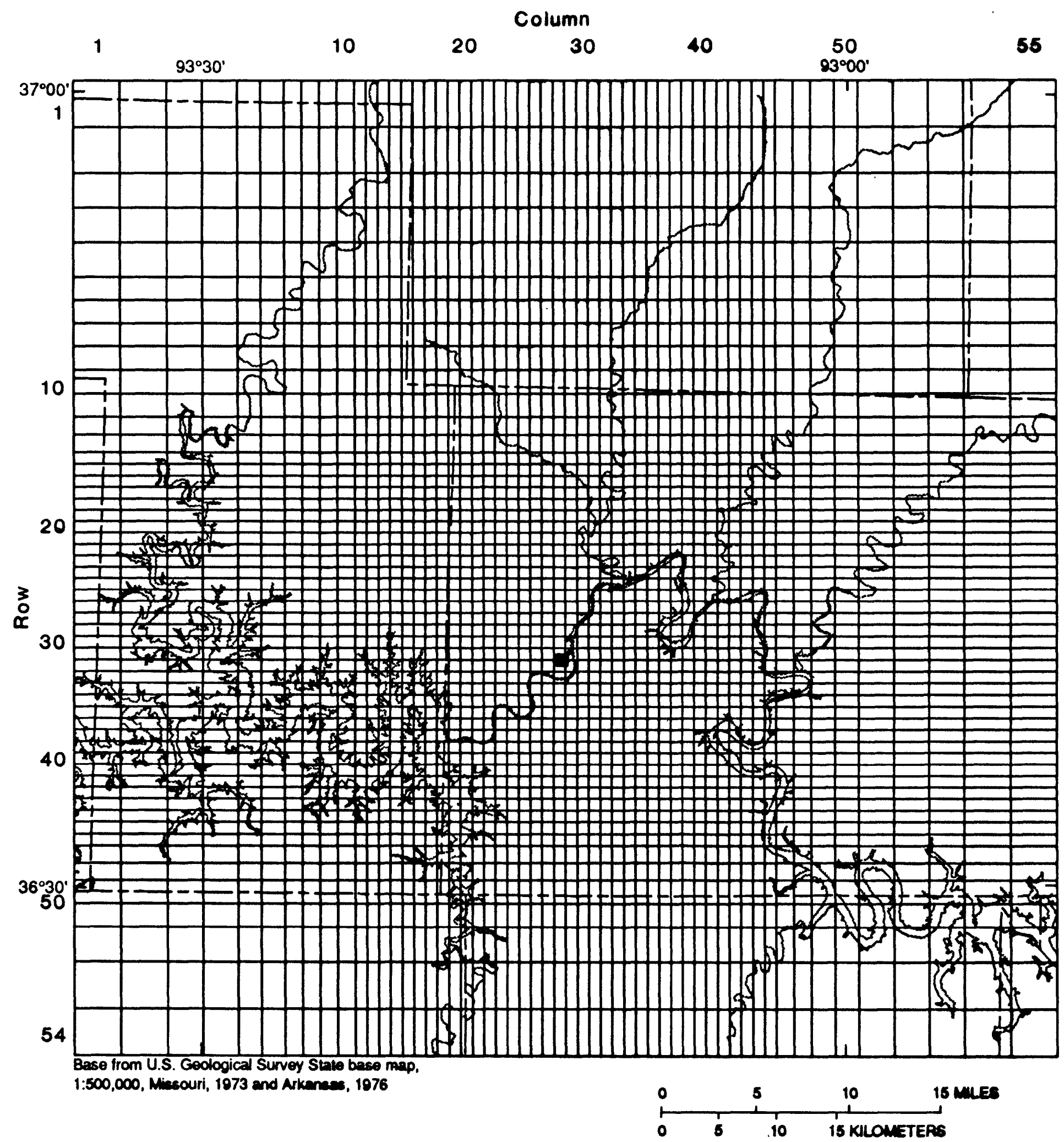

Figure 16.--Extent of modeled area and relative size of model grid cells. 


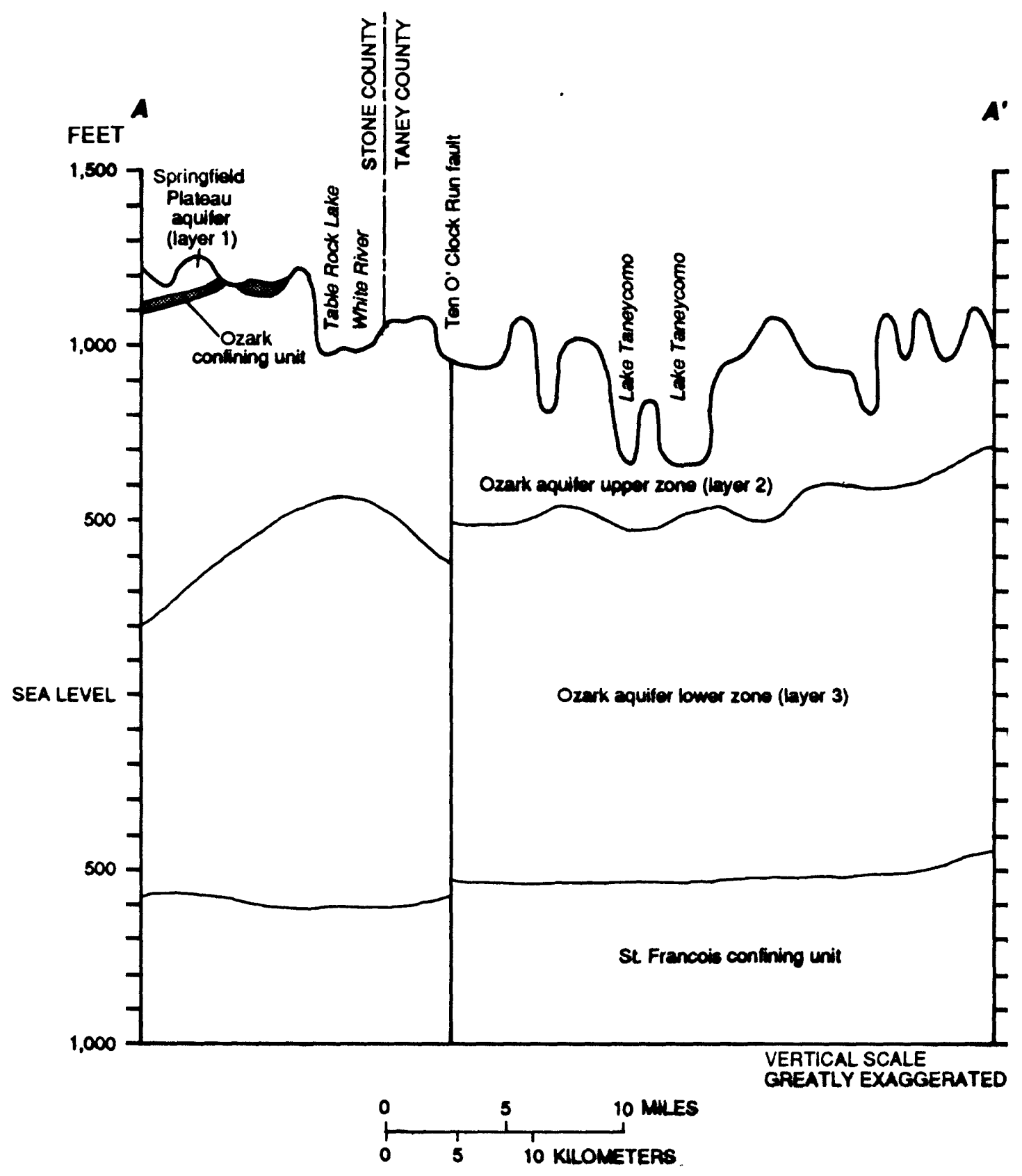

Figure 17.--Geohydrologic section showing relative thickness of the regional geohydrologic units and the model layer representing aquifer units (trace of section in figure 4). 
Calibration of the ground-water flow model to steady-state conditions presented some difficulty. Initially, the steady-state condition for purposes of model calibration was chosen to be the predevelopment-head distribution for the upper zone of the Ozark aquifer (fig. 8). A good representation of the hydraulic head distribution was achieved during the calibration procedure. Because the predevelopment steady-state calibration does not provide a unique model solution, it is necessary to refine the model derived estimates of hydraulic properties by also calibrating the model to a post-development transient condition. However, the only pumping rate data and hydraulic-head measurements available to calibrate the transient model against are from a time period post-dating the creation of Table Rock Lake, Lake Taneycomo, and Bull Shoals Lake. Thus, the post-development transient model must include different boundary conditions than the predevelopment steady-state model. As a result, hydraulic head changes associated with development of the Ozark aquifer cannot be clearly distinguished from model modifications required to simulate vertical leakage through the lake beds and flow through lateral boundaries where the lakes are present at the model boundary.

The accuracy of the model simulations is evaluated by monitoring the average squared error (difference) and the average difference between measured and simulated hydraulic heads. The average squared error is a measure of the overall deviation between measured and simulated hydraulic heads irrespective of whether or not the simulated heads are greater than or less than the measured hydraulic heads. The average difference is a measure of the bias of the simulation; that is, whether the simulated hydraulic heads generally are greater than or less than the measured hydraulic heads. Ideally, both parameters should be minimized to obtain the best calibration. As a result, a decision was made to: (1) calibrate the steady-state simulation to hydraulic heads measured in March 1989 under conditions of minimum seasonal pumping rates; (2) remove pumping from the steady-state calibration to determine the effect of the lakes on the predevelopment potentiometric surface; and (3) calibrate the transient simulation to hydraulic heads measured in June-July 1989 under conditions of maximum seasonal pumping rates using boundary conditions that include the effect of the lakes.

Digital representations of contour maps of the altitude of the top of each important geohydrologic unit and of potentiometric-surface maps for each zone of the Ozark aquifer were developed using Geographic Information System (GIS) techniques. The digitized contour maps were used to generate discretized aquifer thickness data, saturated-rock thickness data, and related information necessary for construction of the flow model.

\section{Model Boundary Conditions}

Vertical boundary conditions control the rate of leakage between the modeled units and the underlying St. Francois aquifer, the rate of recharge to surficial units by percolation of infiltrated precipitation, and the exchange of water between surficial units, streams, and lakes. Lateral boundary conditions control the movement of water through the aquifers at the model edges. The distribution of the recharge rate to the model was derived by adjusting a uniform value to account for different surface conditions. The uniform value is derived from model calibration and is not an independently calculated estimate of recharge. Where Table Rock Lake, Lake Taneycomo, or Bull Shoals Lake are present in a model cell, the uniform value of recharge rate is decreased by the percentage of cell area occupied by the lakes. Where the Ozark confining unit is exposed at land surface, the uniform value of recharge rate is limited to a value no greater than the leakage rate of the confining unit. Because layer 1 is treated as a specified-head layer for steady-state and transient modeling, recharge is intercepted where layer 1 is present.

The lower boundary of the model is treated as an impermeable barrier to ground-water flow. This condition probably is not strictly true because water in the lowermost St. Francois aquifer discharged upward through the Ozark aquifer to the White River before development of the Ozark aquifer as a source of water (Imes and Emmett, in press). The upward gradient from the St. Francois aquifer to the Ozark aquifer probably was decreased after construction of the lakes. However, pumping of water from the lower zone of the Ozark aquifer probably countered the effect of the lakes and reestablished the 
upward gradient. Results of ground-water flow modeling for the Springfield area (Imes, 1989), which is about $40 \mathrm{mi}$ north of Branson, indicate that nearly the entire contribution to water-supply wells is from lateral flow in the Ozark aquifer and downward leakage from the overlying Springfield Plateau aquifer. The relatively thick St. Francois confining unit effectively impedes the upward flow of ground water to wells in the Springfield area. The thickness of the St. Francois confining unit in the Branson area is comparable to the thickness of the unit in the Springfield area. Although Springfield is in an area of regional recharge, whereas Branson is in an area of regional discharge, it is not expected that upward movement of ground water from the St. Francois aquifer to the Ozark aquifer is a significant part of the contribution to wells in the Branson area.

Streams and rivers are simulated by assigning an average stream elevation and an estimated streambed conductivity to each model cell that contains one of the larger streams (fig. 2). These data are used with assigned values of streambed width and thickness to calculate the rate of water exchange between the stream and aquifer in each cell (McDonald and Harbaugh, 1984, p. 6-1). Lakes are simulated using the general-head boundary module of the modular model (McDonald and Harbaugh, 1984, p. 11-1). The value of hydraulic conductance that controls the exchange of water between lakes and aquifers is calculated for each cell using the cell area covered by the lake, the distance between the lake and the mid point of the subjacent upper zone of the Ozark aquifer, and the vertical hydraulic conductivity of the upper aquifer.

Lateral boundary conditions are different for each layer. Because all of layer 1 is modeled as a specified-head condition, lateral boundary conditions for this layer are specified head. Lateral boundary conditions for layer 2 are specified heads, as determined from the predevelopment potentiometric map of the upper zone of the Ozark aquifer (fig. 8), with certain exceptions. An explanation of these exceptions is presented in the sections on steady-state and transient model calibrations. Lateral boundary conditions for layer 3 are no-flow conditions because there is not sufficient hydraulic head data to construct a map of the potentiometric surface of the lower zone of the Ozark aquifer near the model boundary. Estimates of lateral flow in the Ozark and Springfield Plateau aquifers at the model boundaries can be obtained from a previously constructed model of ground-water flow in the Ozark Plateaus aquifer system (Imes and Emmett, in press). However, experience with the Springfield area model indicated that the boundary flow estimates calculated from the steady-state model of the Ozark Plateaus aquifer system were not accurate enough to be useful for boundary conditions for the transient calibration of the Springfield area model (Imes, 1989). It is the opinion of the author that the same situation exists with respect to using results from the Ozark Plateaus aquifer system model to estimate flow at the Branson model boundaries. The boundary conditions used in the model are described in the following section.

\section{Steady-State Calibration: March 1989 Pumping Conditions}

The hydrograph of water levels in well 125 (open to the lower zone of the Ozark aquifer) shows that water levels were stable during the winter of 1988-89 when pumping rates were small compared to pumping rates during the warmer months (fig. 14). The stable configuration of hydraulic heads in the aquifer is indicative that a steady-state condition has been attained. Therefore, it is possible to calibrate the model to March 1989 pumping rates with the assumption that steady-state conditions prevail. The predevelopment hydraulic heads shown in figure 8 cannot be used as specified-head boundaries for layer 2 under March 1989 conditions in areas where the lakes are near the model boundaries. During calibration of the steady-state simulation, lateral boundary conditions at model cells in column 1, from row 20 to row 53, and in column 55, from row 47 to row 53, were set to no-flow conditions. Elsewhere, the predevelopment heads were used as specified-head boundaries. This modification allowed the model to simulate the effect of the lakes near the model boundary. Because ground-water flow near these two segments of the model boundary predominately is parallel to the boundaries and toward the lakes, the simulation of these boundary segments using no-flow conditions probably is a reasonably accurate approximation of the actual flow conditions. 
Ground-water withdrawal by water-supply wells was simulated using the March 1989 groundwater-use data reported by the major water users (table 5). Water withdrawal rates from well 94 (Rockaway Beach 2) were assigned to the upper zone, the producing zone of this shallow well. Wells 219 and 261 are open to both the upper and lower zone, but the primary producing horizons probably are in the lower zone. Thus, pumping rates from these wells were assigned to the lower zone. All other wells in table 5 are open to the lower zone.

Generally, uniform values of lateral and vertical hydraulic conductivity were used in the model calibrations. Model calibration did not yield an estimate of lateral hydraulic conductivity for layer 1 (Springfield Plateau aquifer), because hydraulic heads in layer 1 were held constant during the simulations. The estimated lateral hydraulic conductivity of layer 2, representing the upper zone of the Ozark aquifer, is $3.0 \times 10^{-6} \mathrm{ft} / \mathrm{s}$ (foot per second). Layer 2 is laterally isotropic, thus the distribution of the horizontal hydraulic conductivity is uniform and the lateral to vertical hydraulic conductivity ratio is 10. The lateral hydraulic conductivity of layer 3 , representing the lower zone of the Ozark aquifer, also is laterally isotropic and is estimated at $2.0 \times 10^{-6} \mathrm{ft} / \mathrm{s}$. Layer 3 is laterally isotropic, thus the distribution of the horizontal hydraulic conductivity is uniform. However, the value of lateral hydraulic conductivity for four model cells (row 28 , columns 15 and 16, and row 29, columns 15 and 16) was increased to $2.0 \times 10^{-5} \mathrm{ft} / \mathrm{s}$. The increased conductivity value was applied to these cells to more accurately simulate the situation at Silver Dollar City, a large recreational complex near Branson. Although Silver Dollar City is a large user of ground water (table 5), measured drawdown during times of substantial pumpage in the Silver Dollar City well field is small. However, the wells probably are open to extremely permeable and cavernous rocks associated with the underlying Marvel Cave complex, the deepest cave in Missouri, and the Ten O'Clock Run fault. The lateral to vertical hydraulic conductivity ratio for layer 3 is 10 .

The estimate of vertical hydraulic conductivity for hydraulically restrictive material between layer 1 and layer 2 (primarily represented by the Ozark confining unit) is $1.0 \times 10^{-9} \mathrm{ft} / \mathrm{s}$. No well-defined geohydrologic unit forms hydraulically restrictive material between layers 2 and 3 . The value of vertical hydraulic conductivity representing material that impedes the vertical movement of ground water between layers 2 and 3 was calculated as the effective vertical hydraulic conductivity between the centerlines of layers 2 and 3 . The uniform value of recharge used in the model is $1.0 \times 10^{-9} \mathrm{ft} / \mathrm{s}$. As stated previously, recharge was reduced where the model represented the Springfield Plateau aquifer or lakes and in represented areas where the Ozark confining unit is the surficial unit.

Because the March 1989 potentiometric surface was mapped only for a small area immediately surrounding Branson (fig. 12), the model was not calibrated to a digital representation of the potentiometric surface, but was calibrated to the March 1989 measured hydraulic heads. The average squared error between the March 1989 measured and simulated hydraulic heads for layer 2, based on 16 measured water levels, is $1,674 \mathrm{ft}^{2}$ (foot squared). The average difference between measured and simulated hydraulic heads is $13 \mathrm{ft}$. Simulated hydraulic heads generally agree with the potentiometric surface determined from measured data (fig. 18). One exception occurs at the downstream reach of Lake Taneycomo where simulated hydraulic heads are 10 to $20 \mathrm{ft}$ above the potentiometric surface. However, the simulated hydraulic heads may not be in error here because simulated hydraulic heads for layer 2 are average hydraulic heads over the vertical thickness of the upper zone and represent hydraulic heads at the centerline of the zone, whereas the potentiometric contours derived from measured water levels are drawn consistent with water levels of the lakes. In an area of regional discharge it is reasonable to expect increasing hydraulic head with depth below the discharge areas (lakes). The second area where contours on the simulated and measured heads differ is near the 900$\mathrm{ft}$ closed contour between Lake Taneycomo and Bull Shoals Lake. The $900-\mathrm{ft}$ closed contour is estimated from hydraulic heads measured in June-July 1989 and the accuracy of the contour is assessed with the discussion of the June-July 1989 simulation. 


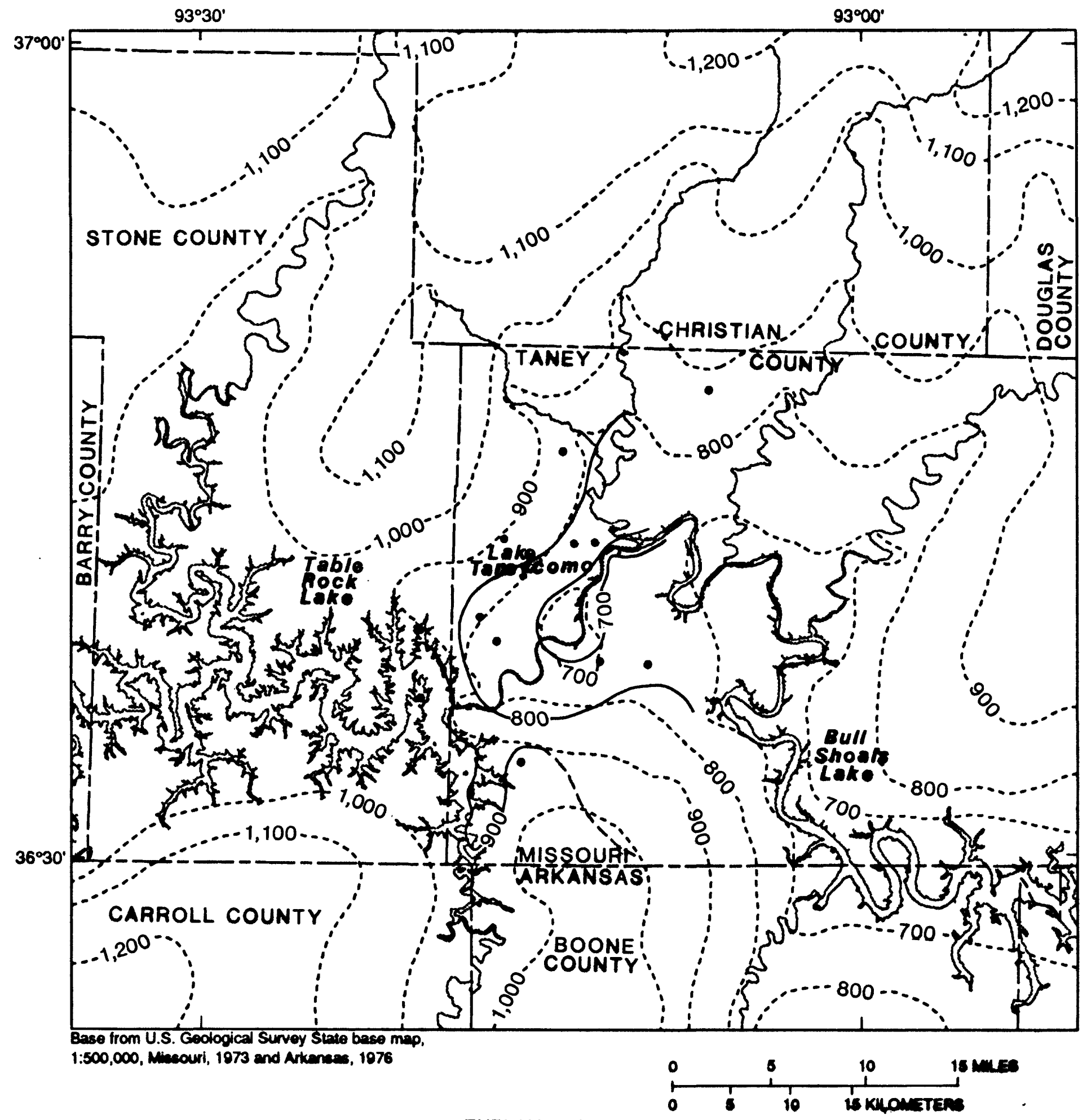

EXPLANATION

-800 - POTENTIOMETRIC CONTOUR--Shows altitude at which measured water lovels would have stood in tightly cased welis. Dached where approximated. Contour interval is 100 feot. Datum is eas bued

----800--.-- SIMULATED POTENTIOMETRIC CONTOUR-Shows altilude of simulated wator bvels. Contour interval, in feet, is variable. Datum is sea bovl

- CONTROL POINT

Figure 18.--Measured and simulated potentiometric surface of the upper zone of the Ozark aquifer, March 1989. 
The average squared error between the March 1989 measured and simulated hydraulic heads for layer 3 is slightly better than that for layer 2 . Based on 13 measured water levels, the average squared error is $1,175 \mathrm{ft}^{2}$. The average difference between measured and simulated hydraulic heads is $-1 \mathrm{ft}$. Again, simulated hydraulic heads generally agree with the potentiometric surface determined from measured data (fig. 19), but simulated hydraulic heads along the downstream end of Lake Taneycomo are 10 to $20 \mathrm{ft}$ above the lake surface, reflecting the upward hydraulic gradient beneath the discharge area.

Ground-water discharge to Bull Creek was simulated at $2.7 \mathrm{ft}^{3} / \mathrm{s}$, which is within 10 percent of the measured 7-day $Q_{2}$ low flow. Discharge to Swan Creek was simulated at $3.3 \mathrm{ft}^{3} / \mathrm{s}$, about 35 percent less than the measured 7-day $Q_{2}$. Comparison of simulated discharge and measured 7-day $Q_{2}$ in other streams are not meaningful because the streams have large drainage areas outside of the model area.

\section{Steady-State Simulation: Predevelopment Conditions with Lakes}

Pumping effects were removed from the calibrated post-development steady-state model to simulate hydraulic heads of the upper and lower zones after construction and filling of Table Rock Lake, Lake Taneycomo, and Bull Shoals Lake and in the absence of pumping stresses. Potentiometric surfaces of the upper and lower zones constructed by contouring simulated hydraulic heads are shown in figures 20 and 21. Comparison of the simulated potentiometric surface of layer 2 (fig. 20) with the pre-lakes (predevelopment) potentiometric surface based on measured water levels (fig. 8) shows that the most notable effect of the lakes on the potentiometric surface of the upper zone is that the $900-\mathrm{ft}$ potentiometric contour crosses the White River channel at Table Rock Dam within the study area instead of crossing beyond the western boundary of the study area. This situation occurs because the average level of Table Rock Lake is $915 \mathrm{ft}$. Changes in the potentiometric surface also are evident in that the 700-ft and 800-ft contours cross the White River channel much farther downstream from their previous positions and that the potentiometric surface in the southeastern corner of the study area is no longer lower than $600 \mathrm{ft}$. Again, these changes occur because the average levels of Lake Taneycomo and Bull Shoals Lake are $700 \mathrm{ft}$ and $650 \mathrm{ft}$, levels that are well above the original river channel bottom.

The simulated predevelopment potentiometric surface of the lower zone (fig. 21) is similar to the simulated predevelopment potentiometric surface of the upper zone. Generally, the simulated potentiometric surface of the upper zone is slightly higher than that of the lower zone in the upland areas of recharge (usually less than $10 \mathrm{ft}$ ) and slightly lower than that of the lower zone in lowland areas of discharge (usually 10 to $20 \mathrm{ft}$ ). Contours on the simulated potentiometric surface of the upper zone tend to show the effect of streams to a greater degree than contours on the simulated potentiometric surface of the lower zone. The exchange of water between Table Rock Lake and the underlying upper zone of the Ozark aquifer is complex. Vertical hydraulic head differences of near 0 to $10 \mathrm{ft}$, indicating an upward gradient, are present throughout most of the area occupied by the lake, with the larger upward gradients concentrated around the lake perimeter. However, a downward gradient is present near Table Rock Dam where lake water flows beneath the dam to emerge at the much lower elevation Lake Taneycomo.

A comparison of the simulated hydraulic heads under predevelopment conditions with lakes present to the simulated hydraulic heads under March 1989 pumping conditions for the upper and lower zones provides an estimate of the effect of current pumping rates on the potentiometric surfaces of the two zones near Branson. The distribution and depth of drawdown in the upper and lower zones of the Ozark aquifer nearly are the same (fig. 22). The only substantial difference between drawdown in the two zones occurs beneath Lake Taneycomo where drawdown in layer 3 is nearly $80 \mathrm{ft}$ and does not seem to be substantially decreased by the presence of the lake. However, the drawdown in layer 2 is less than $40 \mathrm{ft}$ beneath the lake and the drawdown pattern is substantially affected by the lake. The maximum drawdown in both layers is larger than $100 \mathrm{ft}$ but smaller than $150 \mathrm{ft}$ in two areas, one on each side of Lake Taneycomo. The drawdown cone in each layer extends north into Christian County and south into Boone County (Arkansas). The extent of drawdown is limited by induced recharge from 


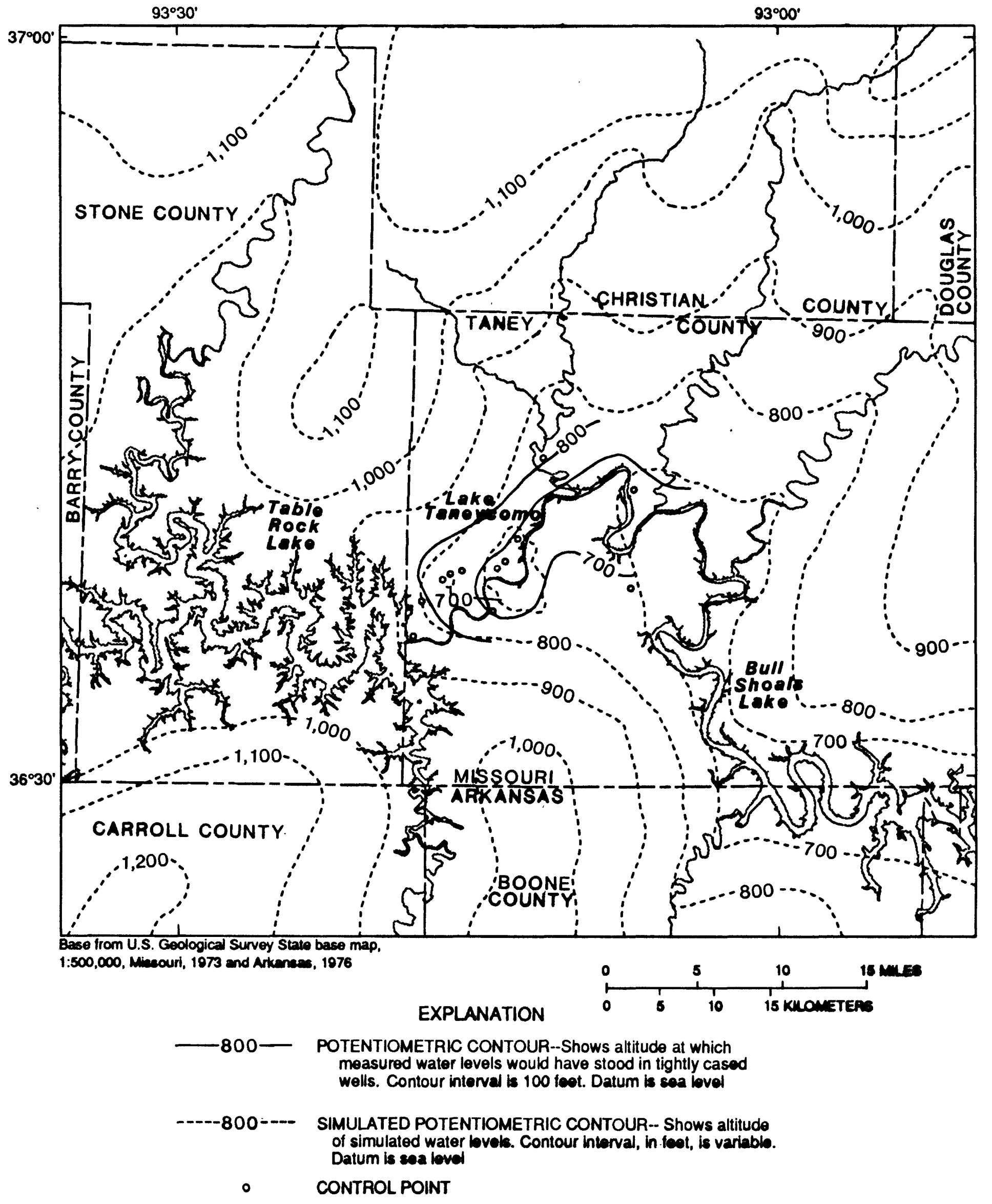

Figure 19.--Measured and simulated potentiometric surface of the lower zone of the Ozark aquifer, March 1989. 


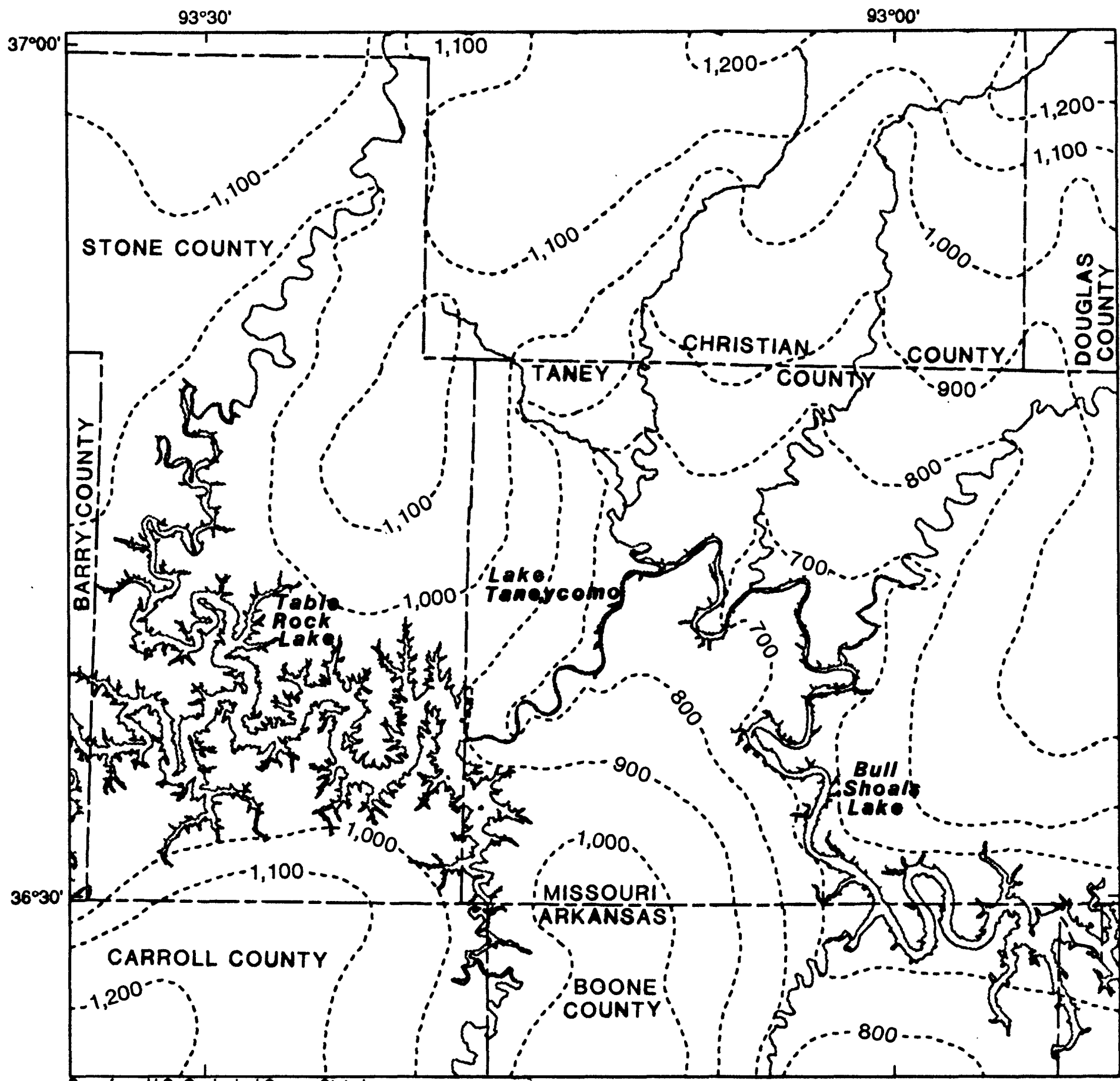

Base from U.S. Godogica Survey State base map, 1:500,000, Miceouri, 1973 and Arkenem, 1076

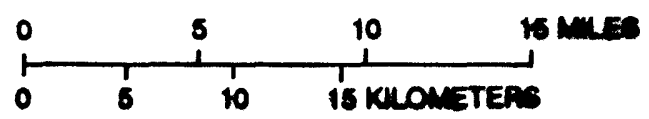

EXPLANATION

-.--800-..- SIMULATED POTENTIOMETRIC CONTOUR--Shows altitudo of simulated water lovels. Contour interval is 100 feet. Datum is soa bval

Figure 20.--Simulated predevelopment potentiometric surface of the upper zone of the Ozark aquifer, including the effect of Table Rock Lake, Lake Taneycomo, and Bull Shoals Lake. 


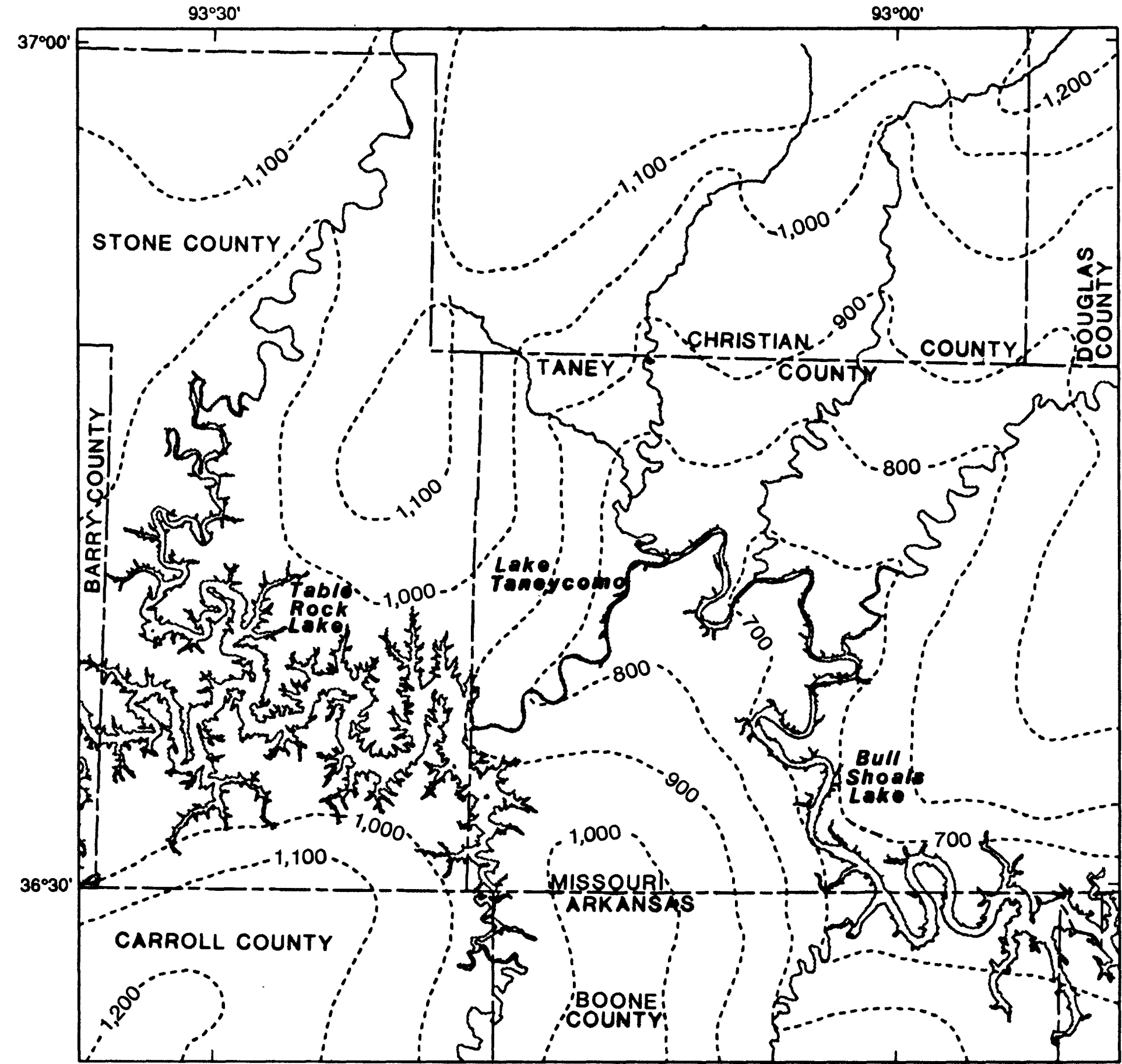

Base from U.S. Geological Survey State base map.

1:500,000, Miscouri, 1973 and Arkanem, 1976

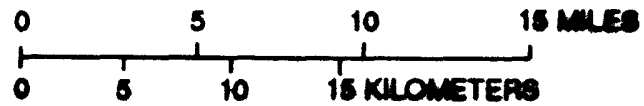

EXPLANATION

-.--800-... SIMULATED POTENTIOMETRIC CONTOUR-Shows alitude

of simulated water bvels. Contour interval b 100 kot. Detum

is can bvel

Figure 21.--Simulated predevelopment potentiometric surface of the lower zone of the Ozark aquiter, including the effect of Table Rock Lake. Lake Taneycomo, and Bull Shoals Lake. 


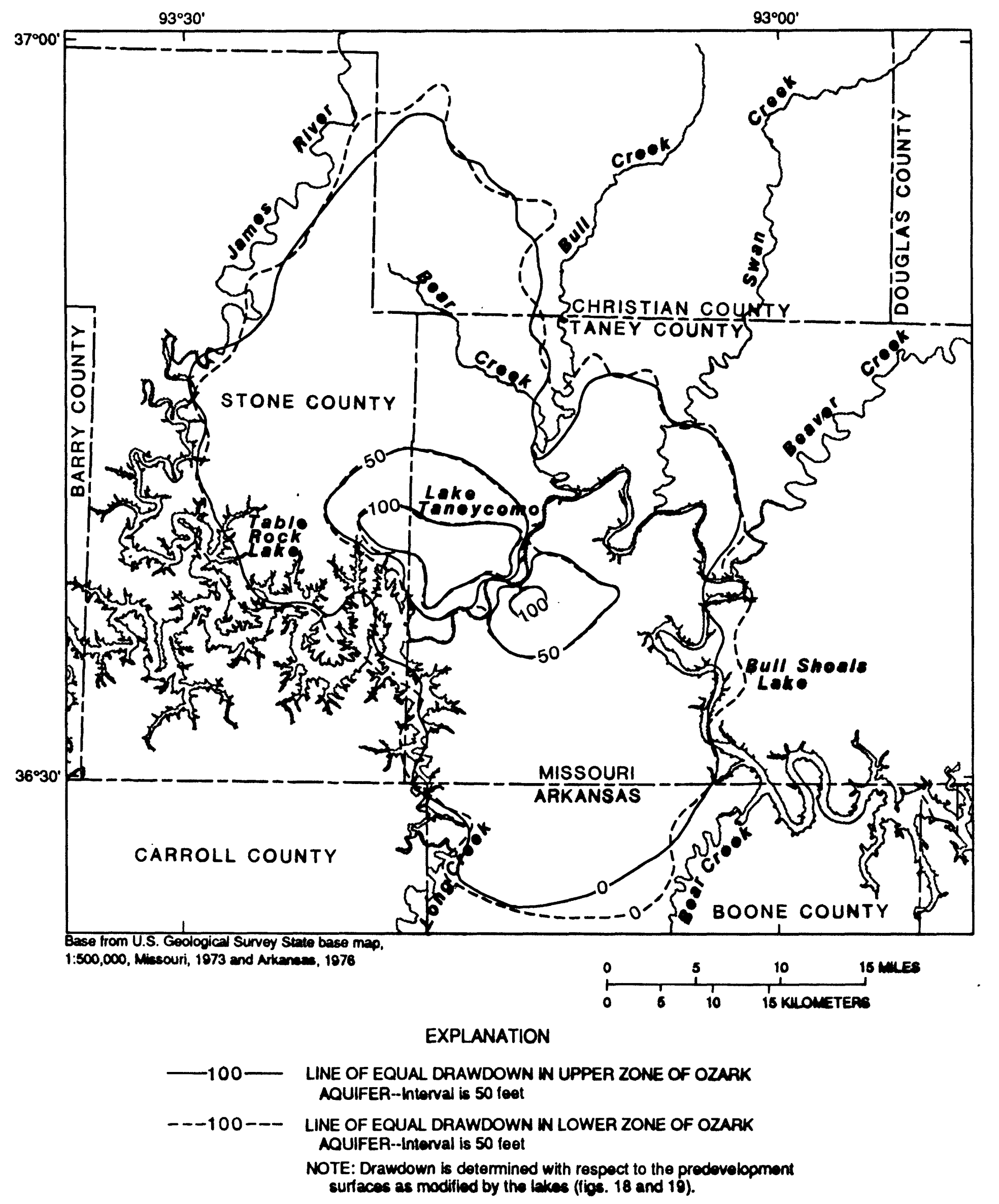

Figure 22.--Drawdown in the upper and lower zones of the Ozark aquifer resulting from pumping stresses in March 1889. 
the lakes and streams. It is likely that the simulations include some boundary effects along the southern boundary where drawdown apparently extends slightly farther south than the southern model boundary.

\section{Transient Calibration: June-Julv 1989 Pumping Conditions}

The ground-water flow model was calibrated under transient conditions to water-levels measured in late June and early July 1989. The specified-head boundary for layer 2 was extended to include all lateral boundary cells. The initial hydraulic heads for layer 2 were set to the hydraulic heads calculated by the steady-state March 1989 calibrated simulation to retain the effect of the lakes on the potentiometric surface at the model boundary.

For the transient calibration, layers 2 and 3 were assigned storage coefficients of 0.004 , except at 4 cells containing the Silver Dollar City well field. Storage coefficients of 0.2 were assigned to these 4 cells. The storage coefficient for layer 2 is more indicative of a confined aquifer than an unconfined aquifer. The small storage coefficient implies that the downward movement of recharge is impeded by less permeable material in the upper zone. Results of the transient calibration validate the assumption that the March 1989 hydraulic-head distribution represents a steady-state situation. The simulation from March 1989 to June 1989 was accomplished in three monthly stress periods of five time steps using pumping rates reported in table 5. The simulated hydraulic heads for each stress period stabilized before the end of the stress period, indicating that steady-state conditions are achieved rather quickly after changes in pumping rates.

The average squared error between the June-July 1989 measured and simulated hydraulic heads for layer 2, based on 42 measured water levels, increased to $3,384 \mathrm{ft}^{2}$, almost twice the error in the steady-state simulation. The average difference between measured and simulated hydraulic heads is $-10 \mathrm{ft}$. Simulated hydraulic heads generally agree with the potentiometric surface determined from measured data (fig. 23) in the lowland areas and upland areas in northern Taney County and Boone County, Arkansas, but are lower than the potentiometric surface in a small area between Lake Taneycomo and Bull Shoals Lake in southwestern Taney County and higher than the potentiometric surface in east-central Stone County. The single measured hydraulic head controlling the 900 -ft closed potentiometric contour in southwestern Taney County is from a relatively shallow well (200 ft) and may not reflect an average hydraulic head for the upper zone of the Ozark aquifer. The potentiometric surface in east-central Stone County may be inaccurately mapped. Six predevelopment water-level measurements taken in wells (not shown) that cluster in this small area ranged from near $1,000 \mathrm{ft}$ to almost 1,200 ft. Apparently, water levels change abruptly with depth in this area. It is not known for certain which water levels accurately reflect the average water level for the upper zone in this area. As with the steady-state simulation, simulated hydraulic heads at the downstream reach of Lake Taneycomo are 10 to $20 \mathrm{ft}$ above the potentiometric surface estimated from measured hydraulic heads. Again, the simulated hydraulic heads may represent average hydraulic heads over the vertical thickness of the aquifer, whereas the potentiometric contours are drawn consistent with the water levels of the lakes.

The average squared error between the June-July 1989 measured and simulated hydraulic heads for layer 3 , based on 16 measured water levels is $1,632 \mathrm{ft}^{2}$. The average difference between measured and simulated hydraulic heads is $-7 \mathrm{ft}$. Simulated hydraulic heads generally agree with the potentiometric surface determined from measured data (fig. 24), except at the downstream end of Lake Taneycomo where simulated hydraulic heads are 10 to $20 \mathrm{ft}$ above the lake surface, reflecting the upward hydraulic gradient beneath the discharge area. 


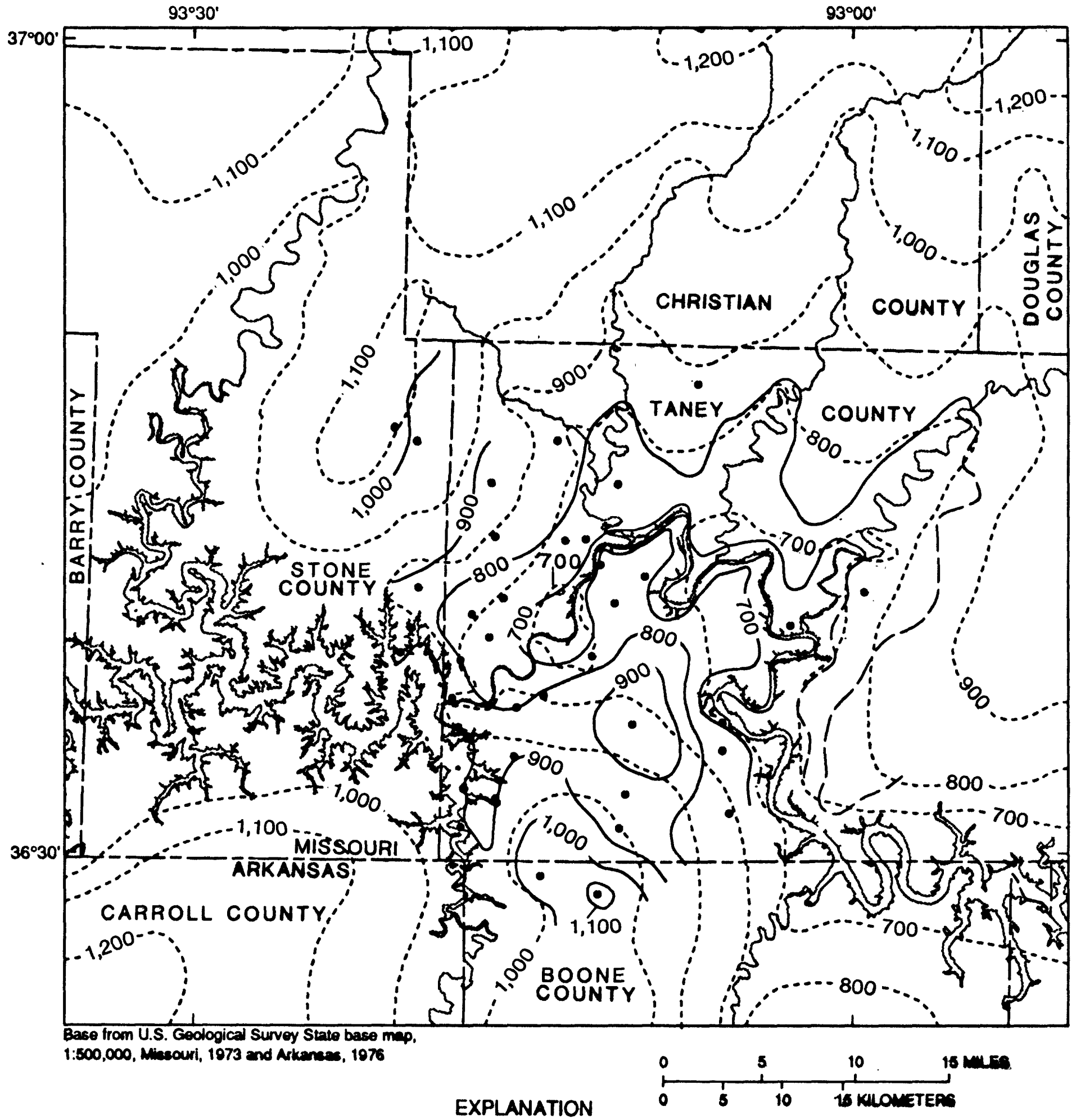

-800 - POTENTIOMETRIC CONTOUR--Shows altitude at which measured water levels would have stood in tightly cased wells. Dashed where approximated.

Contour interval is 100 feet. Datum is sea lovel

- - 800 - - SIMULATED POTENTIOMETRIC CONTOUR--Shows attitude of simulated

water bvols. Contour intorval, in foot, is variabb. Datum is ena lovel

\section{- CONTROL POINT}

Figure 23.--Measured and simulated potentiometric surface of the upper zone of the Ozark aquifer, June-July 1989. 


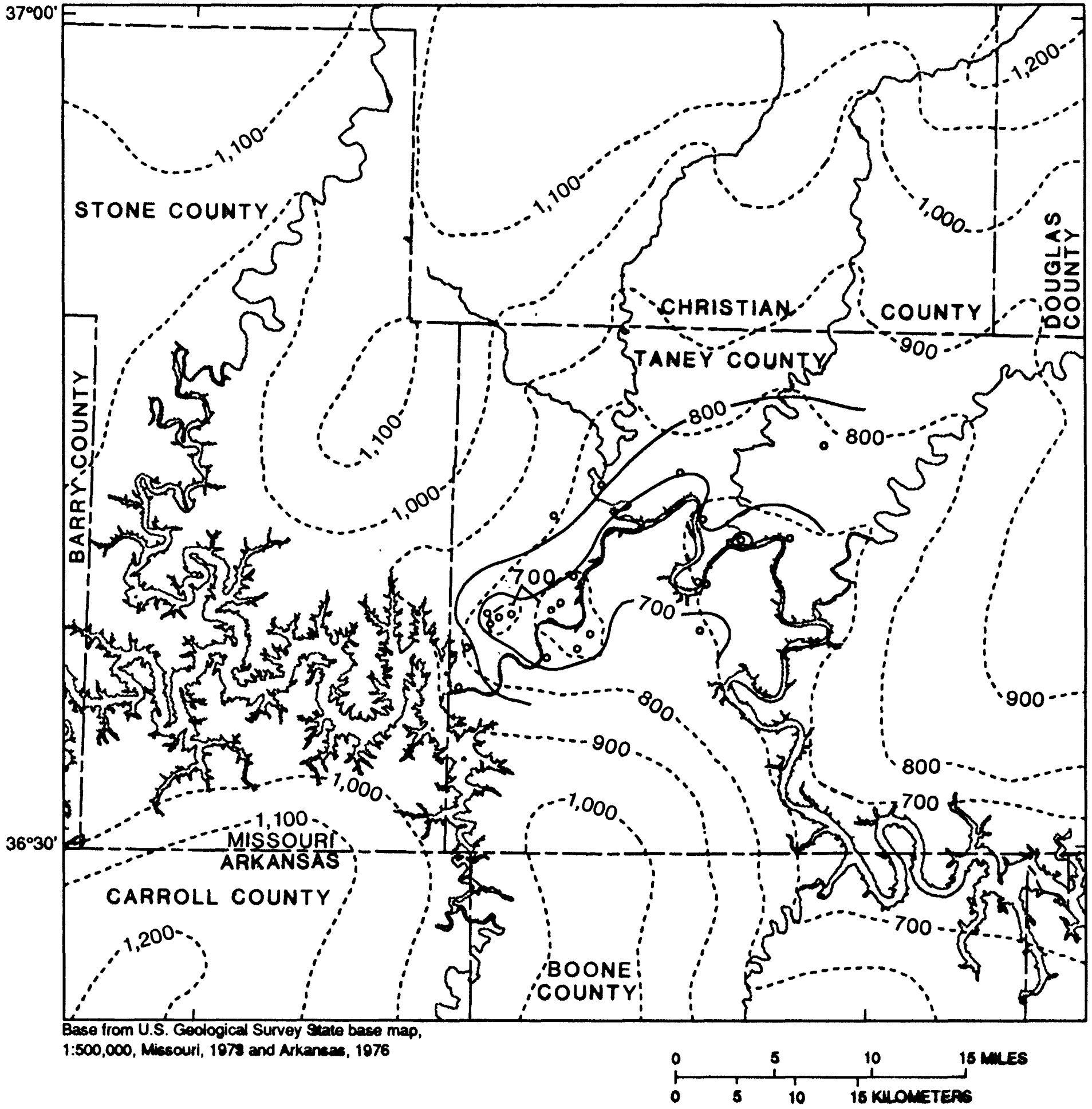

\section{EXPLANATION}

$-800-$ POTENTIOMETRIC CONTOUR-Shows altitude at which measured water levels would have stood in tightly caced wolle. Contour interval is 100 feat. Datum is saa bvel

800---- SIMULATED POTENTIOMETRIC CONTOUR--Shows altitude of simulated water lovels. Contour interval, in foet, is veriablo. Datum is sea level

- CONTROL POINT

Figure 24.--Measured and simulated potentiometric surface of the lower zone of the Ozark aquifer, Juno-July 1000. 


\section{Sensitivity Analysis}

The sensitivity of the calibrated June 1989 model simulation to a 50 percent increase and a 50 percent decrease in the value of selected hydraulic variables was analyzed to qualitatively assess the accuracy of the simulation. The effect of variable changes on the hydraulic head simulation for layers 2 and 3 was monitored by calculating the average squared difference and average difference between the simulated and measured hydraulic heads. Changes in the lateral hydraulic conductivity of layer 2 generally failed to improve the simulation accuracy for one or both layers (table 6). The maximum head changes (about $10 \mathrm{ft}$ ) were localized in layer 2 near and slightly downstream from Table Rock Dam. A 50 percent increase in the lateral hydraulic conductivity of layer 3 produced a small improvement in the accuracy of layer 2 and layer 3 simulated hydraulic heads, except for an increase in the average difference for layer 3. Hydraulic head changes for both layer 2 and layer 3 were localized around Branson.

Table 6.--Sensitivity of calibrated June 1989 model simulation to changes in hydraulic variables

[K, hydraulic conductivity; L, leakage coefficient, coeff., coefficient; S, storage coefficient; subscripts indicate layer number]

\begin{tabular}{lccccc}
\hline & & \multicolumn{2}{c}{ Layer 2 } & \multicolumn{2}{c}{ Layer 3 } \\
\cline { 4 - 6 } $\begin{array}{c}\text { Hydraulic } \\
\text { variable }\end{array}$ & $\begin{array}{c}\text { Percent } \\
\text { change }\end{array}$ & $\begin{array}{c}\text { Average squared } \\
\text { difference }\end{array}$ & $\begin{array}{c}\text { Average } \\
\text { difference }\end{array}$ & $\begin{array}{c}\text { Average squared } \\
\text { difference }\end{array}$ & $\begin{array}{c}\text { Average } \\
\text { difference }\end{array}$ \\
\hline & & & & & \\
No change & 0 & 3,291 & -10 & 1,621 & -8 \\
$\mathrm{~K}_{2}$ lateral & -50 & 3,332 & -10 & 1,622 & -7 \\
$\mathrm{~K}_{2}$ lateral & +50 & 3,278 & -11 & 1,635 & -8 \\
$\mathrm{~K}_{3}$ lateral & -50 & 3,308 & -10 & 1,948 & 0 \\
$\mathrm{~K}_{3}$ lateral & +50 & 3,281 & -11 & 1,618 & -13 \\
$\mathrm{~L}_{1-2}$ & -50 & 3,291 & -10 & 1,621 & -8 \\
$\mathrm{~L}_{1-2}$ & +50 & 3,291 & -10 & 1,621 & -8 \\
$\mathrm{~L}_{2-3}$ & -50 & 3,303 & -11 & 1,599 & -6 \\
$\mathrm{~L}_{2-3}$ & +50 & 3,286 & -10 & 1,650 & -8 \\
Lakebed leakage coeff. & -50 & 3,282 & -11 & 1,625 & -8 \\
Lakebed leakage coeff. & +50 & 3,304 & -10 & 1,629 & -8 \\
$\mathrm{~S}_{2}$ & -50 & 3,284 & -11 & 1,633 & -8 \\
$\mathrm{~S}_{2}$ & +50 & 3,303 & -10 & 1,628 & -7 \\
$\mathrm{~S}_{3}$ & -50 & 3,295 & -10 & 1,629 & -5 \\
$\mathrm{~S}_{3}$ & +50 & 3,291 & -10 & 1,653 & -9 \\
Recharge & -50 & 3,289 & -10 & 1,617 & -8 \\
Recharge & +50 & 3,311 & -11 & 1,633 & -8 \\
\hline
\end{tabular}

The model is insensitive to changes in the leakage coefficient between layers 1 and 2 . Changes in the leakage coefficient between layers 2 and 3 improved the simulation of hydraulic heads for one layer at the expense of a less accurate simulation of hydraulic head for the other layer. The maximum hydraulic head changes were about $5 \mathrm{ft}$. Most changes were only about 1 to $2 \mathrm{ft}$ and were scattered throughout the simulation. However, an increase of 50 percent in the leakage coefficient between layers 2 and 3 produced hydraulic head changes that correlated with the location of streams. Changes in storage coefficients did not improve the model. A slight improvement was noted when recharge was decreased by 50 percent.

The sensitivity analysis indicates that no major improvement in model accuracy can be made by further refining the model calibration. Slight improvements may possibly be made to the model by adjusting the lateral hydraulic conductivity of layer 3 and recharge, but flow directions and volumes will not be substantially changed. The model probably is most sensitive to the lateral hydraulic conductivity of layer 3 . 


\section{Predevelopment and Post-Development Hydrologic Budgets}

Volumetric flow rates derived from the calibrated ground-water flow model can provide information about net ground-water movement and changes in flow volumes in response to stress. Comparison of the model water budget under predevelopment conditions (including the effect of lakes) with the model water budget for March 1989, after pumping stresses have altered ground-water flow patterns, indicates that the source of most of the $4.3 \mathrm{ft}^{3} / \mathrm{s}$ of water pumped from the lower zone is a combination of increased recharge from the upper zone and decreased discharge to the upper zone (fig. 25). Under predevelopment conditions, net flow from the upper zone to the lower zone was zero and net flow to streams and lakes was $36.9 \mathrm{ft}^{3} / \mathrm{s}$. Because of pumping, net flow to the lower zone in March 1989 was a net $4.3 \mathrm{ft}^{3} / \mathrm{s}$. The resulting loss of water from the upper zone decreased net flow to streams and lakes to $32.7 \mathrm{ft}^{3} / \mathrm{s}$, a loss of 11 percent of the prepumping discharge to streams and lakes. About $0.1 \mathrm{ft}^{3} / \mathrm{s}$ of the water pumped from wells comes from larger induced leakage from the Springfield Plateau aquifer.

\section{Estimates of Future Drawdown:-June-July 2010}

To estimate the effect of future pumping stresses on the Ozark aquifer, the calibrated groundwater flow model was used to simulate the potentiometric surface of the upper and lower zones of the aquifer in June-July 2010. Pumping rates were estimated to increase 20 percent every 10 years during the 20-year simulation period. This increase in pumping rate is arbitrary but provides a basis from which an estimate of the effect of possible future pumping rates on the potentiometric surfaces of the upper and lower zones can be calculated. When estimates of future ground-water needs are determined by rigorous analysis of water requirements for the Branson area, the more accurate estimates can be incorporated into the model. Because most of the large-capacity wells in the Branson area are open to the lower zone of the Ozark aquifer, estimated drawdown in the lower zone is larger than the drawdown in the upper zone. Using the estimated pumping rates, the increased drawdown in the upper zone is simulated to be larger than $1 \mathrm{ft}$, but less than $10 \mathrm{ft}$, in three small areas centered about the Rockaway Beach, Forsyth, and Taney County Public Water Supply District 2 wells (fig. 26). A larger area of increased drawdown surrounds Branson and Hollister. The increased drawdown exceeds $10 \mathrm{ft}$ only in a small area centered on the more recently developed western edge of Branson.

Estimated increased drawdown in the lower zone of the Ozark aquifer also exceeds $1 \mathrm{ft}$, but is less than $10 \mathrm{ft}$, in areas centered on Kimberling City, Silver Dollar City, Rockaway Beach, Forsyth, and Taney County Public Water Supply District 2 wells (fig. 27). The increased drawdown around Branson and Hollister is larger than the corresponding increase in the upper zone. The maximum increased drawdown in the lower zone exceeds $30 \mathrm{ft}$ near the western edge of Branson and exceeds $20 \mathrm{ft}$ near the eastern edge of Branson. Although the increased drawdown will require larger lift distances to pump ground water to water-supply tanks and supply lines, these simulations indicate that, under the assumption of a 20 percent increase in pumping rates every 10 years, ground-water supplies will be adequate for municipal, commercial, and domestic uses to 2010 . However, it is possible that some shallow domestic wells in the areas of larger increased drawdown will need to be deepened in the future.

\section{SUMMARY}

The demand for potable water to supply recreation facilities, commercial establishments, lodging facilities, and residences has increased in Branson, Missouri, the center of a rapidly developing retirement community and tourist industry. The rapid pace of business and residential expansion has caused concerns regarding the future ground-water quality and availability. This study was designed to provide a reconnaissance of ground-water quality in the Branson area and estimate the long-term effect of the large summer water demand. 


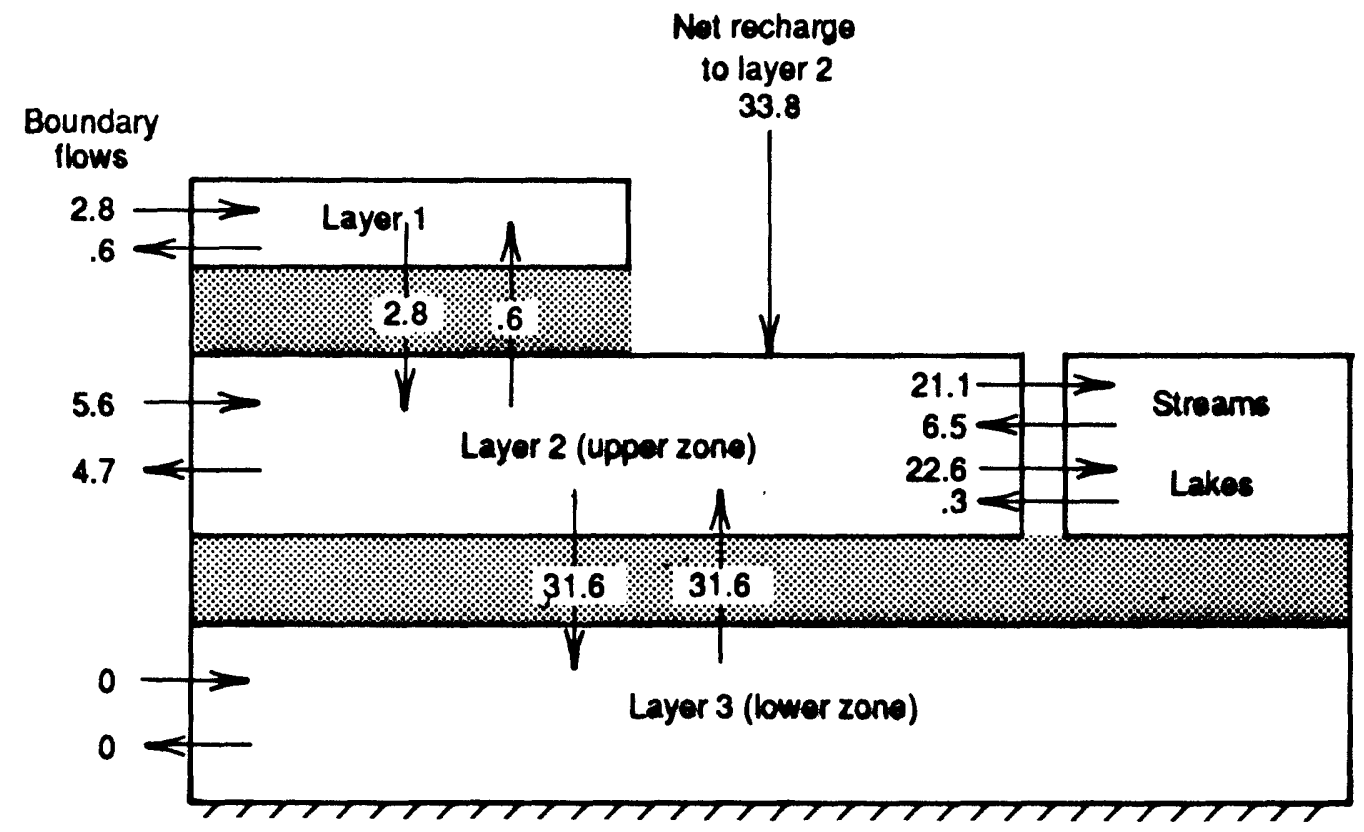

Predevolopment water budget, including effect of lakes.

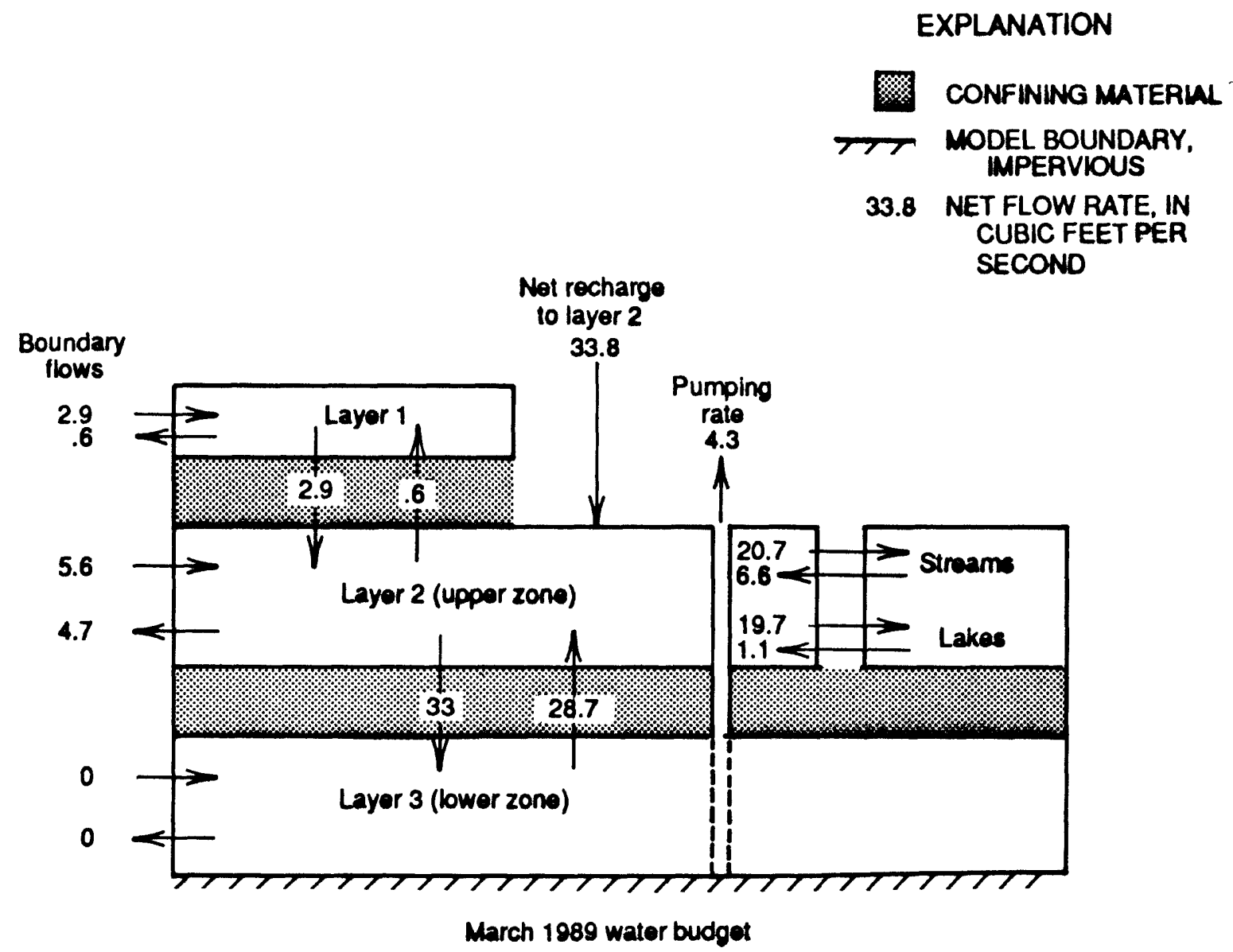

Figure 25.-- The predevelopment water budget (including lakes) and the March 1989 water budget. 


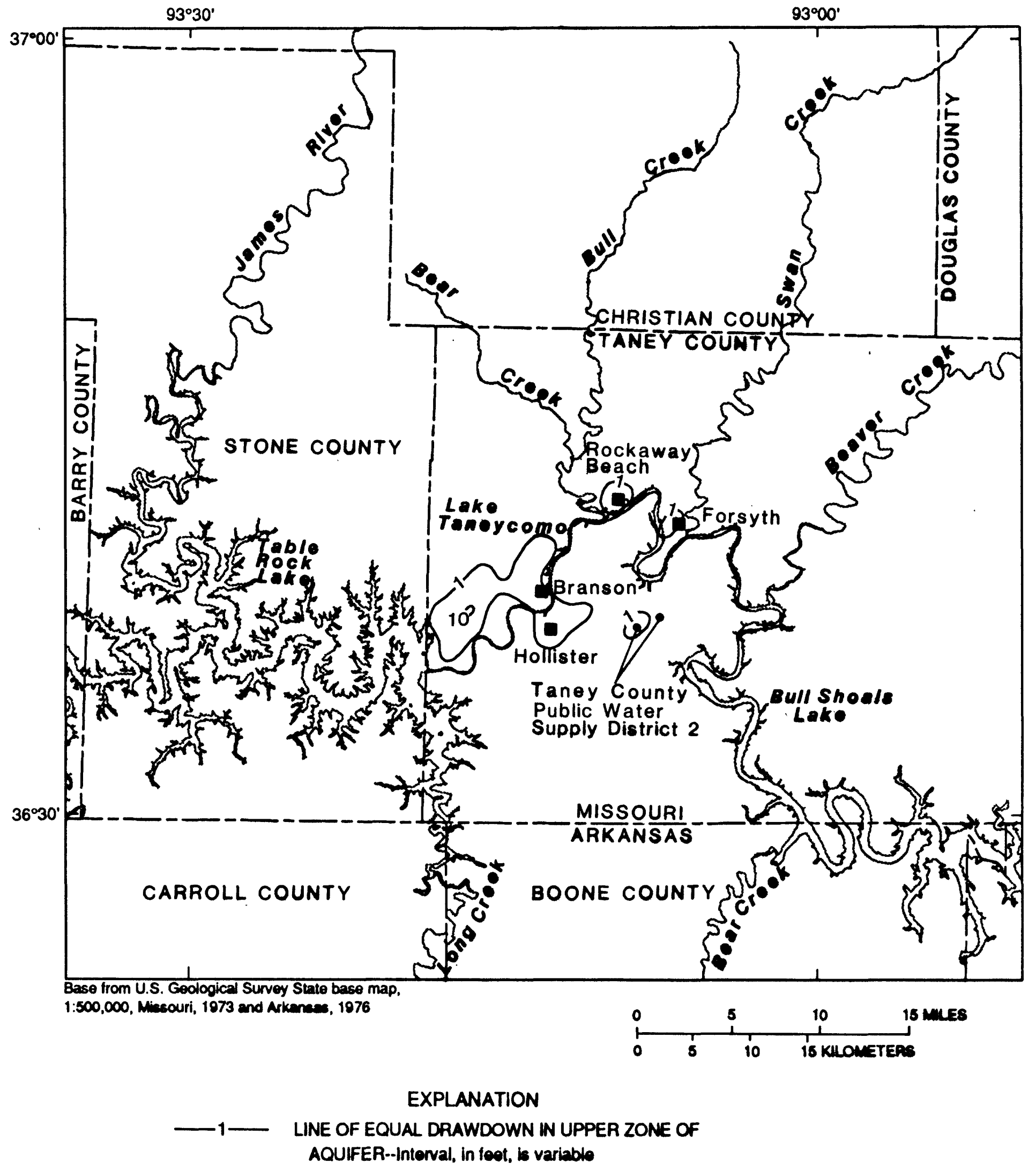

Figure 26--Pumpage induced drawdown in the upper zone of the Ozark aquifer from June 1989 to Jun 2010. 


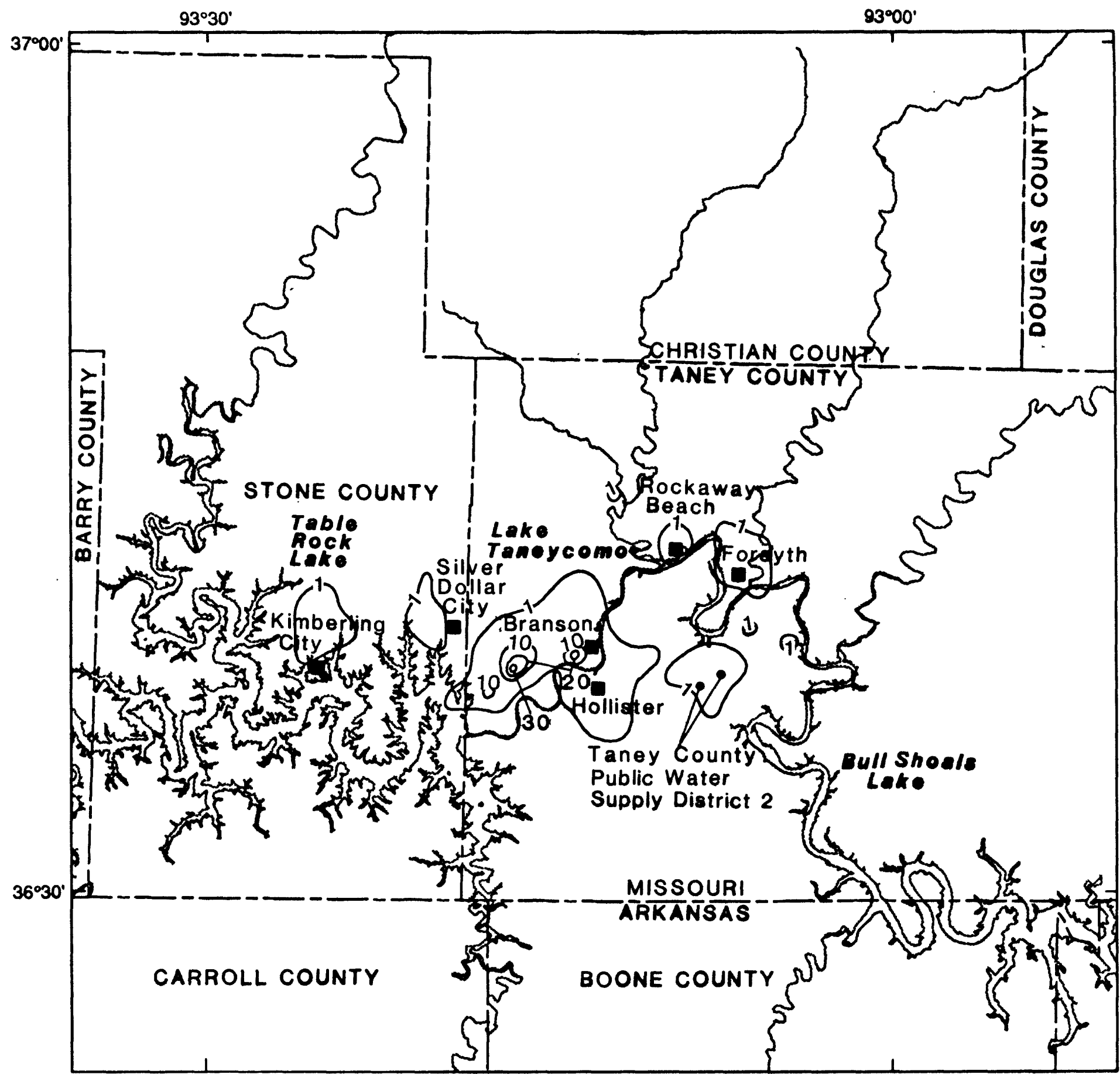

Base from U.S. Geological Survey State base map,

1:500,000, Miescouri, 1973 and Akensas, 1976

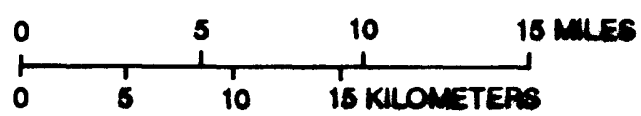

EXPLANATION

- $1-$ LINE OF EQUAL DRAWDOWN WN LOWER ZONE OF

AOUIFER--Interval, in feot, Is variablo

Figure 27.--Pumpage induced drawdown in the lower zone of the Ozark aquifer from June 1989 to June 2010.' 
- All water supply wells in the Branson area withdraw water from the Ozark aquifer, a permeable sequence of dolostone and sandstone formations. Within the study area, the Ozark aquifer can be divided into two distinct zones based on permeability contrasts. The upper zone, which comprises of formations stratigraphically higher than and including the Jefferson City Dolomite, is the less permeable zone. The lower zone, comprised of formations stratigraphically lower than and including the Roubidoux Formation, is the more permeable zone.

A survey of 34 wells to determine the concentrations of fecal coliform bacteria and inorganic chemicals usually indicative of water contamination indicated no fecal coliform bacteria present in any well, and no unusually large concentration of inorganic chemicals. Chloride and nitrate concentrations in all water samples were less than the Missouri Department of Natural Resources criteria for publicdrinking water supply. Specific conductance of the water samples ranged from 347 to $841 \mu S / \mathrm{cm}$. An analysis of 5 water samples for a suite of 33 volatile organic compounds failed to detect the presence of any of the compounds.

Measurements of water levels made during the summer of 1987, June-July 1988, March 1989, and June-July 1989 show that seasonal variations in ground-water levels can be greater than $100 \mathrm{ft}$. The seasonal changes primarily result from changes in the rate of water use during the summer tourist season as compared to the winter months. Interpretative potentiometric maps based on all measured water levels indicate no evidence of a pattern of declining water-levels on a long-term basis. Water levels in a well open to the lower zone of the Ozark aquifer were monitored from September 1988 to March 1990. The water levels in the well, located in the city of Branson, were stable during the winter of 1988-89, but declined by about $30 \mathrm{ft}$ from winter $1988-89$ to summer 1989 . The water level recovered to the previous winter height in the winter of 1989-90. Water use by the city of Branson ranges from about 20 to 25 million gallons per month in winter to about 50 million gallons per month during the summer tourist season.

A three-dimensional ground-water flow model was developed to simulate flow in the upper and lower zones of the Ozark aquifer. The model was calibrated to March 1989 pumping conditions. A hydrograph of water levels in a well open to the lower zone of the Ozark aquifer in Branson shows that it is reasonable to assume steady-state conditions at the end of the winter period. The model was used to simulate the probable hydrologic effect of the construction and filling of Table Rock Lake, Lake Taneycomo, and Bull Shoals Lake. A transient calibration was accomplished by incorporating simulation of aquifer storage into the model and simulating the effect of changing pumping rates from March 1989 to June 1989. The model probably is most sensitive to changes in the lateral hydraulic conductivity of layer 3 (the lower zone of the Ozark aquifer). Model simulations confirm that water levels in the Ozark aquifer respond quickly to changes in pumping rates. Water levels will continue to oscillate seasonally with changes in pumping rates. However, it seems that long-term declines in water levels will not occur unless mean annual pumping rates increase in the study area.

The calibrated model was used to simulate the probable effect of a 20 percent increase in pumping rates every 10 years from June 1989 to June 2010. Estimated water levels in the lower zone of the Ozark aquifer decline by a maximum of about $30 \mathrm{ft}$ under this simulation; water levels in the upper zone of the Ozark aquifer also decline, but only by a maximum of about $10 \mathrm{ft}$. The areas of maximum estimated decline are centered in the more recently-developed western edge of Branson. 


\section{REFERENCES CITED}

Brown, J.C., Jr., 1988, Groundwater assessment of the Lake Taneycomo area, Taney County, Missouri: Missouri Department of Natural Resources, Division of Geology and Land Survey, unpublished report.

Imes, J.L., 1989, Analysis of the effect of pumping on ground-water flow in the Springfield Plateau and Ozark aquifers near Springfield, Missouri: U.S. Geological Survey Water Resources Investigations Report 89-4079, 63 p.

1990a, Major geohydrologic units in and adjacent to the Ozark Plateaus province, Missouri, Arkansas, Kansas, and Oklahoma--St. Francois confining unit: U.S. Geological Survey Hydrologic Investigations Atlas HA-711-D, 3 sheets.

1990b, Major geohydrologic units in and adjacent to the Ozark Plateaus province, Missouri, Arkansas, Kansas, and Oklahoma--Ozark aquifer: U.S. Geological Survey Hydrologic Investigations Atlas HA-711-E, 3 sheets.

Imes, J.L., and Emmett, L.F., in press, Geohydrology of the Ozark Plateaus aquifer system in parts of Missouri, Arkansas, Oklahoma, and Kansas: U.S. Geological Survey Professional Paper 1414-F.

McDonald, M.G., and Harbaugh, A.W., 1984, A modular three-dimensional finite-difference groundwater flow model: U.S. Geological Survey Open-File Report 83-875, 528 p.

Melton, R.W., 1976, Regional geohydrology of the Roubidoux and Gasconade Formations, Arkansas and Missouri: Fayetteville, University of Arkansas, unpublished M.S. thesis, 160 p.

Missouri Department of Natural Resources, 1987, Missouri water-quality standards--Chapter 7, Water quality: Jefferson City, Clean Water Commission.

State of Missouri, 1890-1988, Official manual--Census statistics: Jefferson City, published biennially. 